This report has been reproouced directly from the best available copy.

Aveilable to DOE and DOE contractors from the Otfice of Scientific and Technical Information, P.O. Box 62, Oak Ridge, TN 37831; prices available from (615) 576-8401, FTS 626-8401.

Available to the public from the National Technical Information Service, U.S. Department of Commerce, 5285 Port Royal Rd., Springfield, VA 22161.

This report was prepared as an account of work sponsored by an agency of the United States Government. Neither the United States Government nor any agency thereof, nor any of their employees, makes any warranty, express or implied, or assumes any legal liability or responsibility fo accuracy, completeness, or usefulness of any information, apparatus, product, or process disclosed, or represents that its use would not infringe privately owned rights. Reference herein to any specific commercial product, process, or service by trade name, trademark, manufacturer, or otherwise, does not necessarily constitute or imply its endorsement, recommendation, or favoring by the United States Government or any agency thereof. The views and opinions of authors expressed herein do not necessarily state or reflect those of the United States Government or any agency therent. 
Engineering Technology Division

\title{
CALMAC ICE STORAGE TEST REPORT
}

\author{
Therese K. Stovall
}

DATE PUBLISHED: August 1991

Prepared for the

Electric Power Research Institute

under Interagency Agreement No. DOE ERD-85-502

Prepared by the

OAK RIDGE NATIONAL LABORATORY

Oak Ridge, Tennessee 37831-6285 managed by

MARTIN MARIETTA ENERGY SYSTEMS, INC.

for the

U.S. DEPARTMENT OF ENERGY under contract DE-AC05-840R21400 


\section{CONTENTS}

Page

LIST OF FIGURES $\quad \ldots \ldots \ldots \ldots \ldots \ldots \ldots \ldots \ldots \ldots \ldots \ldots \ldots \ldots \ldots \ldots$

LIST OF TABLES $\ldots \ldots \ldots \ldots \ldots \ldots \ldots \ldots \ldots \ldots \ldots \ldots \ldots \ldots \ldots \ldots \ldots$

ABBREVIATIONS AND SYMBOLS $\ldots \ldots \ldots \ldots \ldots \ldots \ldots \ldots \ldots \ldots \ldots$

ACKNOWLEDGMENTS $\ldots \ldots \ldots \ldots \ldots \ldots \ldots \ldots \ldots \ldots \ldots \ldots \ldots \ldots \ldots \ldots \ldots$

ABSTRACT $\ldots \ldots \ldots \ldots \ldots \ldots \ldots \ldots \ldots \ldots \ldots \ldots \ldots \ldots \ldots \ldots \ldots \ldots \ldots \ldots \ldots$

1. INTRODUCTION $\ldots \ldots \ldots \ldots \ldots \ldots \ldots \ldots \ldots \ldots \ldots \ldots \ldots \ldots \ldots \ldots \ldots$

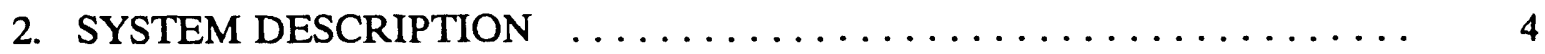

2.1 CALMAC STORAGE SYSTEM $\ldots \ldots \ldots \ldots \ldots \ldots \ldots \ldots \ldots$

2.2 TEST FACILITY $\ldots \ldots \ldots \ldots \ldots \ldots \ldots \ldots \ldots \ldots \ldots \ldots \ldots \ldots \ldots$

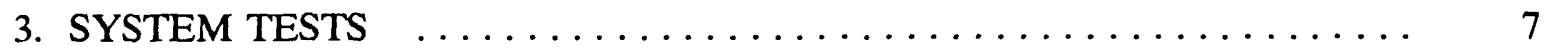

4. ANALYSIS METHODOLOGY $\ldots \ldots \ldots \ldots \ldots \ldots \ldots \ldots \ldots \ldots \ldots \ldots$

4.1 DATA PROCESSING $\ldots \ldots \ldots \ldots \ldots \ldots \ldots \ldots \ldots \ldots \ldots \ldots \ldots \ldots$

4.2 REFRIGERATION EFFECT $\ldots \ldots \ldots \ldots \ldots \ldots \ldots \ldots \ldots \ldots \ldots \ldots \ldots$

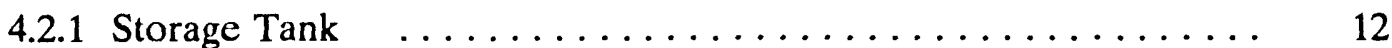

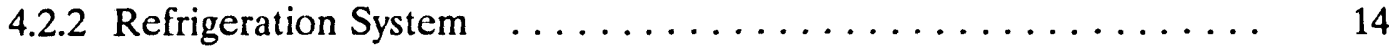

4.2.3 Capacity Models and Capacity Normalization $\ldots \ldots \ldots \ldots . \ldots 15$

4.3 DISCHARGE ENERGY AVAILABLE $\ldots \ldots \ldots \ldots \ldots \ldots \ldots \ldots$

4.4 SHELL HEAT GAINS $\ldots \ldots \ldots \ldots \ldots \ldots \ldots \ldots \ldots \ldots \ldots \ldots \ldots \ldots$

5. RESULTS $\ldots \ldots \ldots \ldots \ldots \ldots \ldots \ldots \ldots \ldots \ldots \ldots \ldots \ldots \ldots \ldots \ldots \ldots \ldots \ldots$

5.1 CHARGING PERFORMANCE $\ldots \ldots \ldots \ldots \ldots \ldots \ldots \ldots \ldots \ldots$

5.2 DISCHARGE PERFORMANCE $\ldots \ldots \ldots \ldots \ldots \ldots \ldots \ldots \ldots \ldots \ldots$

5.3 STANDBY HEAT GAINS $\ldots \ldots \ldots \ldots \ldots \ldots \ldots \ldots \ldots \ldots \ldots \ldots \ldots \ldots$

5.4 EUTECTIC PERFORMANCE $\ldots \ldots \ldots \ldots \ldots \ldots \ldots \ldots \ldots \ldots .40$

6. CONCLUSIONS AND RECOMMENDATIONS $\ldots \ldots \ldots \ldots \ldots \ldots \ldots .46$

REFERENCES $\ldots \ldots \ldots \ldots \ldots \ldots \ldots \ldots \ldots \ldots \ldots \ldots \ldots \ldots \ldots \ldots \ldots \ldots \ldots \ldots \ldots$

APPENDIX A: ISTF INSTRUMENTATION $\ldots \ldots \ldots \ldots \ldots \ldots \ldots \ldots$ 


\section{LIST OF FIGURES}

Figure

1 ISTF schematic for Calmac storage system

2 Summary of Calmac charge tests with water in tank and brine concentration of $33 \%$, both capacity and stored latent energy based on brine temperature and flow measurements $\ldots \ldots \ldots \ldots$

3 Summary of Calmac charge tests with water in tank and brine concentration of $25 \%$, both capacity and stored latent energy based on brine temperature and flow measurements $\ldots \ldots \ldots \ldots$

$4 \quad$ Normalized capacity of Calmac charge tests with water in tank and brine concentration of $33 \%$, normalized relative to average

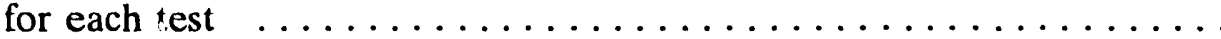

5 Normalized capacity of Calmac charge tests with water in tank and brine concentration of $33 \%$, generated by test-specific mathematical models of normalized capacity as function of tank charge, normalized relative to average for each test

6 Summary of tank brine inlet temperature profiles for all Calmac charge tests with water and brine concentration of $33 \%$

7 Summary of tank brine inlet temperature profiles for all Calmac charge tests with water and brine concentration of $25 \%$

8 Tank inlet temperature vs calculated stored energy for Calmac charge tests with average capacity from 18 to 20 tons and brine flow rates of 40,60 , and $80 \mathrm{gal} / \mathrm{min}$

9 Average of tänk inlet and outlet temperatures vs calculated stored energy for Calmac charge tests with average capacity from 18 to 20 tons and brine flow rates of 40,60 , and $80 \mathrm{gal} / \mathrm{min}$

10 Tank inlet temperature vs calculated stored energy for Calmac charge tests with brine flow rate of $60 \mathrm{gal} / \mathrm{min}$ with various average capacities and two different brine concentrations

11 Average of tank inlet and outlet temperatures vs calculated stored energy for Calmac charge tests with brine flow rate of $60 \mathrm{gal} / \mathrm{min}$ with various average capacities and two different

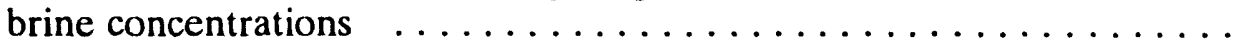

12 Comparison of measured average brine inlet temperatures to

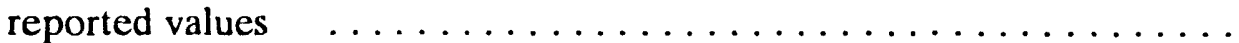

13 Comparison of measured minimum brine inlet temperatures to

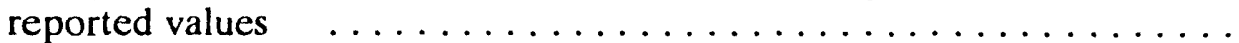

14 Example of packaged chiller capacity data for two condensing

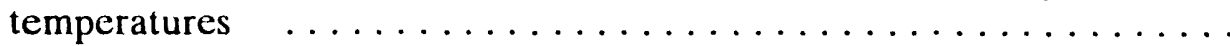




\section{LIST OF FIGURES (continued)}

\section{Figure}

15 Capacity vs storage tank brine inlet temperature for tank charges from 25 to $100 \%$ frozen for Calmac storage tank at

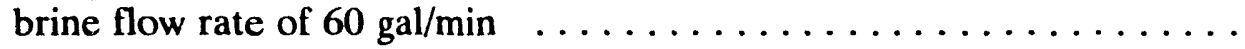

16 Application of package chiller data to ice storage data when designing system $\ldots \ldots \ldots \ldots \ldots \ldots \ldots \ldots \ldots \ldots \ldots \ldots \ldots \ldots \ldots \ldots \ldots$

17 Summary of cumulative energy storage in ice tank for Calmac charge tests

18 Comparison of discharge energy as measured at three different locations from test run on Jan. 29, $1990 \ldots \ldots \ldots \ldots \ldots \ldots \ldots$

19 Calmac discharge test summary for water with tank inlet temperature of $60^{\circ} \mathrm{F}$ : tank water outlet temperature vs tank

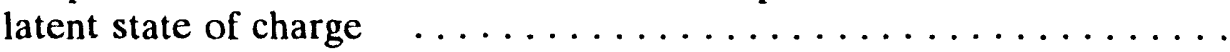

20 Calmac discharge test summary for water with tank inlet temperature of $50^{\circ} \mathrm{F}$ : tank water outlet temperature vs tank

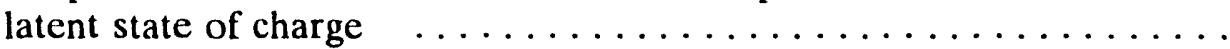

21 Calmac discharge test summary for tests with tank inlet temperature of $60^{\circ} \mathrm{F}$

22 Calmac discharge test summary for tank filled with water with tank inlet of $60^{\circ} \mathrm{F}$ : cumulative discharge energy available for maximum tank outlet temperatures of 36,40 , 44 , and $48^{\circ} \mathrm{F}$ for different discharge rates $\ldots \ldots \ldots \ldots \ldots$

23 Calmac discharge test summary for tank filled with water with tank inlet of $50^{\circ} \mathrm{F}$ : cumulative discharge energy available for maximum tank outlet temperatures of 36,40 , and $44^{\circ} \mathrm{F}$ for different discharge rates $\ldots \ldots \ldots \ldots \ldots \ldots$

24 Selected Calmac discharge tests to compare effects of brine concentration on brine tank outlet temperature $\ldots \ldots \ldots \ldots \ldots$

25 Selected Calmac discharge tests to compare effects of brine concentration on brine flow rate $\ldots \ldots \ldots \ldots \ldots \ldots \ldots \ldots$

26 Summary of Calmac charge tests with eutectic material in tank and brine concentration of $33 \%$, both capacity and stored latent energy based on brine temperature and flow measurements

27 Summary of tank brine inlet temperature profiles for Calmac charge tests with eutectic material and brine concentration

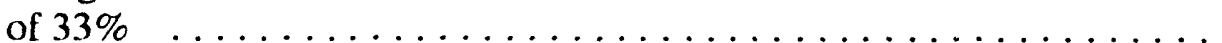

Summary of Calmac discharge test tank outlet temperatures with tank inlet of $50^{\circ} \mathrm{F}$ and eutectic storage medium 


\section{LIST OF FIGURES (continued)}

\section{Figure}

Page

29 Comparison of tank outlet temperature during discharge tests with eutectic vs water as storage medium $\ldots \ldots \ldots \ldots \ldots \ldots \ldots \ldots$

30 Calmac discharge test summary for eutectic material with tank inlet temperature of $50^{\circ} \mathrm{F}$ : tank water outlet temperature vs tank latent state of charge $\ldots \ldots \ldots \ldots \ldots \ldots \ldots \ldots \ldots \ldots \ldots \ldots \ldots \ldots$

31 Calmac discharge test summary for eutectic material with tank inlet temperature of $60^{\circ} \mathrm{F}$ : tank water outlet temperature vs

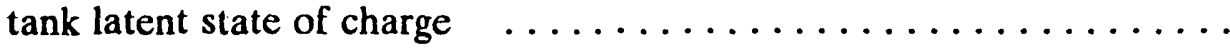




\section{LIST OF TABLES}

Table

Page

1 ISTF monitoring points for the Calmac brine coil system $\ldots \ldots \ldots 6$

2 Planned charge test sequence $\ldots \ldots \ldots \ldots \ldots \ldots \ldots \ldots \ldots \ldots$

$3 \quad$ Planned discharge test sequence $\ldots \ldots \ldots \ldots \ldots \ldots \ldots \ldots \ldots$

$4 \quad$ Planned standby test sequence $\ldots \ldots \ldots \ldots \ldots \ldots \ldots \ldots \ldots$

$5 \quad$ Calmac charge test summary $\ldots \ldots \ldots \ldots \ldots \ldots \ldots \ldots \ldots$

$6 \quad$ Calmac discharge test summary $\ldots \ldots \ldots \ldots \ldots \ldots \ldots \ldots \ldots$

$7 \quad$ Parameter estimates for Eqs. (18) and (19) $\ldots \ldots \ldots \ldots \ldots \ldots$

$8 \quad$ Eutectic charge test comparisons $\ldots \ldots \ldots \ldots \ldots \ldots \ldots \ldots \ldots \ldots$

9 Eutectic discharge test comparisons $\ldots \ldots \ldots \ldots \ldots \ldots \ldots \ldots \ldots$ 


\section{ABBREVIATIONS AND SYMBOLS}

$\mathrm{Cap}_{\mathrm{h}}$ discharge capacity measured at heater

$\mathrm{Cap}_{\mathfrak{\imath}}$ discharge capacity measured at ice tank

$c_{p} \quad$ specific heat

DPDE1 difference between tank water depth and fully melted tank water depth

FE1 refrigerant mass flow to the expansion valves

FE3 brine flow to ice tank

FE4 brine flow from the evaporator

FE5 refrigerant volumetric flow to the condenser

FE6 water flow rate

HE1 refrigerant enthalpy entering the condenser

HE2 refrigerant enthalpy leaving the condenser

HE10 enthalpy corresponding to the measured suction temperature and pressure of the superheated refrigerant leaving the chiller/evaporator

ISTF Ice Storage Test Facility

PDE1 tank water depth

$\dot{\mathrm{Q}}_{\mathbf{c}}$

$\dot{\mathbf{Q}}$

Q.

$\mathrm{Re}_{\mathrm{b}}$ heat of rejection predicted by the compressor manufacturer

heat rejected by the refrigerant

heat absorbed by the cooling water

refrigeration effect as determined by measured brine flow rate and temperature change at ice storage tank

$\mathrm{Re}_{\mathrm{bn}} \quad$ capacity, normalized relative to the average capacity

$\mathrm{Re}_{\mathrm{c}} \quad$ refrigeration capacity predicted by the capacity curves

$\mathrm{RE}_{\mathrm{fch}} \quad$ refrigeration effect as determined by measured refrigerant flow rates and thermodynamic properties

SC state of charge

SG specific gravity

T temperature

TE11 brine temperature entering heater

TE12 brine temperature leaving heater

TE15 brine temperature leaving the ice tank

TE16 brine temperature entering the ice tank

TE17 brine temperature leaving the chiller/evaporator 


$\begin{array}{ll}\text { TE18 } & \text { brine temperature entering the chiller/evaporator } \\ \text { TE19 } & \text { water temperature exiting the condenser } \\ \text { TE20 } & \text { water temperature into the condenser } \\ T_{d} & \text { saturated discharge temperature } \\ \text { T-h } & \text { ton-hour } \\ T_{s} & \text { saturated suction temperature } \\ \dot{W}_{c} & \text { compressor power predicted by the manufacturer's data } \\ \text { VE1 } & \text { refrigerant specific volume entering the condenser } \\ \rho & \text { density } \\ \tau & \text { time }\end{array}$


xiii

\section{ACKNOWLEDGMENTS}

This important research has been made possible by the support of the Electric Power Research Institute. I would like to thank the program manager, Ronald Wendland, for his critical support and enthusiasm. Calmac Manufacturing Corporation provided the unit for testing. John Tomlinson of Oak Ridge National Laboratory designed the Ice Storage Test Facility, supervised its construction, and has provided valuable guidance during the testing process. Delmar Fraysier is the chief operator of the test facility and made important contributions to the test procedures. 


\title{
CALMAC ICE STORAGE TEST REPORT
}

\author{
Therese K. Stovall
}

\begin{abstract}
The Ice Storage Test Facility (ISTF) is designed to test commercial ice storage systems. Calmac provided a storage tank equipped with coils designed for use with a secondary fluid system. The Calmac ice storage system was tested over a wide range of operating conditions. Measured system performance during charging was similar to that reported by the manufacturer. Both the measured average and minimum brine temperatures were in close agreement with Calmac's literature values, and the ability to fully charge the tank was relatively unaffected by charging rate and brine flow rate. During discharge cycles, the storage tank outlet temperature was strongly affected by the discharge rate. The discharge capacity was dependent upon both the selected discharge rate and maximum allowable tank outlet temperature. Based on these tests, storage tank selection musi depend most strongly on the discharge conditions required to serve the load.

This report describes Calmac system performance fully under both charging and discharging conditions. Companion reports describe ISTF test procedures and ice-making efficiency test results that are common to many of the units tested.
\end{abstract}

\section{INTRODUCTION}

Commercial air-conditioning loads are a large component of the afternoon peak loads served by electric utilities. Increased use of cool storage would shift this electrical load from peak to off-peak periods. This shift would permit utilities to defer construction of additional generating capacity and reduce customers demand charges.

Although the number of cool storage installations in commercial buildings is growing, it represents only a small fraction of the potential market. One major barrier to the use of cool storage equipment has been the uncertainty associated with its performance. Uniform testing by an independent agency has not been available. The performance data available from manufacturers are varied in scope and detail from one type of device to another and

\footnotetext{
"Units used throughout this report are common to and exclusive in the industry.
} 
across manufacturers as well. Often system performance values are given for only one operating point, making it difficult to predict performance under other operating conditions.

Electric Power Research Institute (EPRI) therefore sponsored the development of an Ice Storage Test Facility (ISTF) to permit uniform testing of commercial-size cool storage equipment of many different types. This testing serves two purposes: (1) to provide uniform performance test results and (2) to promote system improvements based or experimental data. Uniform test results will re useful to utilities in promoting their installation and use and in requesting rate incentives from public utilities commissions (PUCs) and to building designers in specifying appropriate equipment for their applications. The experimental data will also be useful to equipment designers because it will describe component behavior as well as overall system performance. The capacity of the ISTF was sized at 250 ton-h. Real-time data acquisition and precise computer controls were included.

The ISTF can be used to test dynamic, liquid recirculation, secondary fluid, and direct expansion (DX) ice makers. The simplest ice maker is a DX machin\%. In a DX ice maker, the refrigerant is sent as a cold liquid into coils submerged in a tank of water. As the refrigerant passes through these coils, it absorbs heat from the water and evaporates. As the refrigerant leaves the coils, it is completely gaseous and usually slightly superheated. The water in the tank is thereby chiled until it becomes frozen. When the stored cooling is needed, the ice is melted by circulating warm water from the heat load through the ice and returning the chilled water to the heat load. This arrangement is called an exterior melt because the ice is melted from the surface opposite from the surface where the ice is formed.

In a secondary fluid system, the cold liquid refrigerant is sent to a heat exchanger outside the tank of water. In this heat exchanger, a secondary fluid, typically a glycol mixture, is chilled. This secondary fluid is then sent to the tank of water where it absorbs heat from the water, again freezing the water in the tank. The secondary fluid can also be used to transfer the stored cooling to the heat load. This arrangement is called an internal melt. The stored cooling energy can also be transferred to the heat load by using an external melt as described for the DX system.

A liquid recirculation system is similar to the DX system because the cold refrigerant is sent to coils submerged in the tank of water. However, in the liquid recirculation system, the amount of refrigerant circulated through the coils is typically two to three times greater than in a DX system so that only a pnrtion of the refrigerant is evaporated and the coils 
remain full of liquid throughout their length. This additional refrigerant circulation is accomplished through the use of gravity feed or a refrigerant pump. The stored cooling energy is transferred to the heat load using an external melt arrangement.

A dynamic ice maker freezes ice using either a DX or a liquid overfeed arrangement. However, in a dynamic system, the ice is harvested on a periodic basis. This harvesting cycle reduces the ice thickness on the heat transfer surface of the chiller. After the ice is harvested, it is stored in a slush or slurry of ice and water. The water is circulated to provide the stored cooling to the heat load.

This report describes the test results for an ice storage tank furnished by the Calmac Manufacturing Corporation. The Calmac storage tank is both charged and discharged using a secondary fluid or brine. The storage system and the test facility are described in Sect. 2. Section 3 describes the tests that were performed to characterize the storage system, and Sect. 4 describes the analysis methods used to evaluate the performance data. The results and recommendations are summarized in Sects. 5 and 6. 


\section{SYSTEM DESCRIPTION}

\section{CALMAC STORAGE SYSTEM}

The Calmac model 1190 ice tank is chilled by the flow of brine through 5/8-in.-OD plastic tubing, spaced roughly $11 / 2$ in. (center to center) apart. These tubes are submerged in water. The brine used for these tests was a mixture of ethylene glycol and water with a freezing point of $\sim 0^{\circ} \mathrm{F}$. Calmac recommends a mixture with a slightly lower ethylene glycol concentration, and a few tests were run at its recommended concentration. The tank can be frozen nearly solid, leaving only a minimum amount of free water to fill the voids that occur near the heat exchanger tubing when the ice first begins to melt. The Calmac ice tank is discharged by circulating the brine through the tank and then through the desired heat load, simulated by a simple heater in the test facility. The Calmac tanks are equipped with a water depth sensor that can be used to infer the amount of ice stored during a charging cycle and the state of charge during a discharge cycle. ${ }^{1}$

When the Calmac tanks were filled with the specified volume of 1620 gal of water, the water level was $\sim 3 \mathrm{in}$. higher than the recommended level of $10 \mathrm{in}$. below the fill port. During the first charge cycle, a small amount of water overflowed the tank, leaving a new fully melted water level $\sim 0.7$ in. lower than the initial level. Based on the volume vs water level calibration for this tank, that level change amounted to $\sim 12$ gal of water. The volume of brine in the storage system was not measured.

\subsection{TEST FACILITY}

The test facility was designed to test a wide variety of storage systems. It includes all refrigeration system components necessary to charge brine systems. Figure 1 shows the test facility configuration used to test the Calmac storage tank equipped with the brine coils. The test facility is well-equipped with monitoring devices to measure temperature, pressure, flow, and energy use. The monitoring points shown in Fig. 1 are listed in Table 1. A clear plastic tube was inserted into the tank near the tank wall (where the water usually remains unfrozen) and looped and secured outside the tank to facilitate reliable measurements of water level. Before each level measurement was recorded, the tube inside the tank was checked to be sure that it was free of ice. The measured water level reflects changes in the tank water depth 


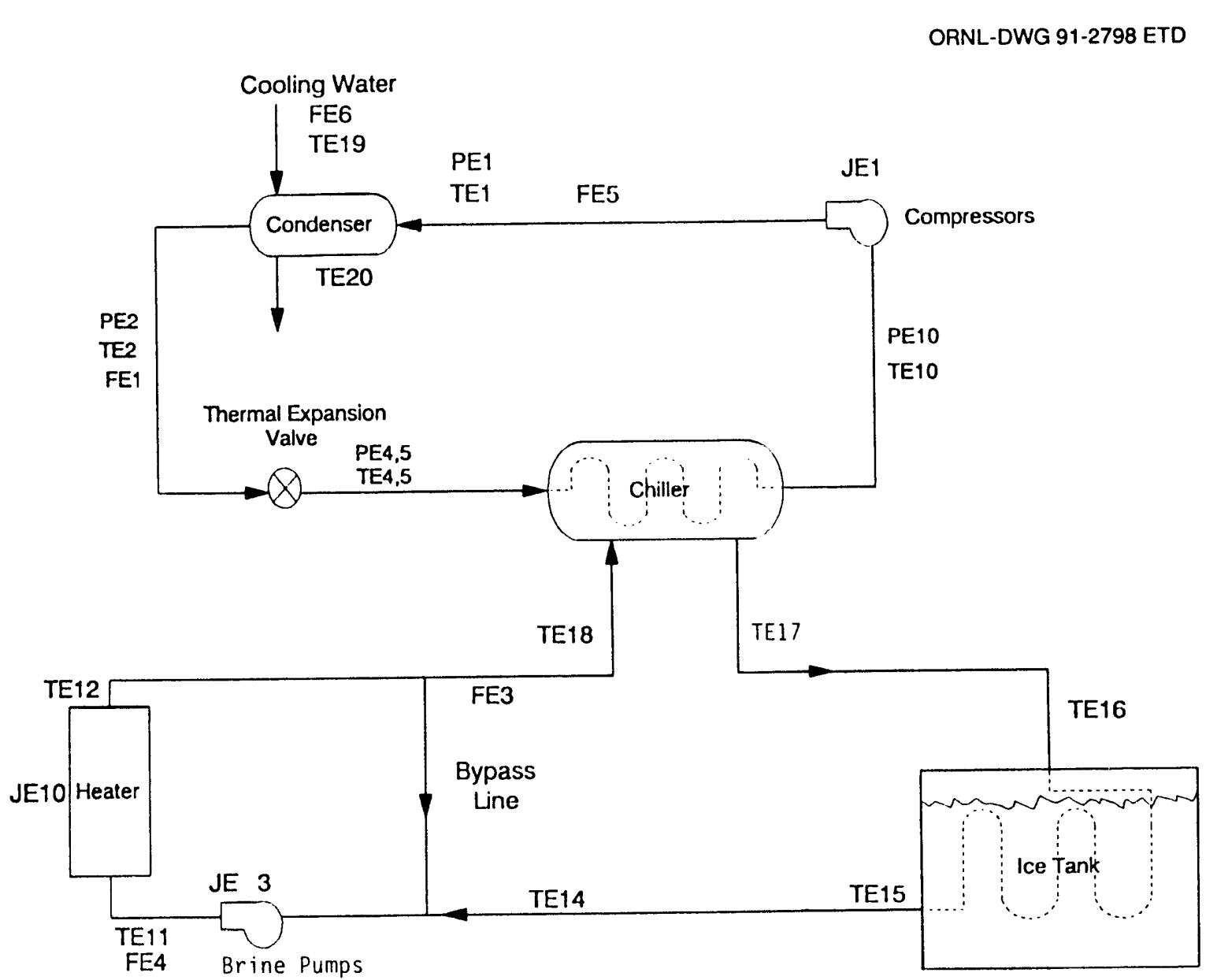

Fig. 1. ISTF schematic for Calmac storage system.

that occur during freezing due to the difference in density between ice and water. The test loop instrumentation is described more fully in Appendix A and Ref. 2.

A variable speed pump was used to circulate brine during both the charge and discharge cycies, as is shown in Fig. 1. The evaporator/chiller (see Fig. 1) connects the test facility's refrigeration system to the brine loop that charges the ice storage tank. In the evaporator/chiller, a refrigerant is vaporized, absorbing heat from the brine. To accommodate the desired wide range of testing conditions, a chiller with two independent and equal-size refrigerant coils was selected. The control system is designed to select one or both chiller coils based on the compressor loading. The thermal expansion valves feeding refrigerant to these coils open and close in response to the measured superheat at the coil exit. Because the evaporator/chiller was often running under part-load conditions, the thermal expansion 
Table 1. ISTF monitoring points

for the brine coil system

\begin{tabular}{cl}
\hline Point label & \multicolumn{1}{c}{ Measured quantity } \\
\hline FE1 & Chiller inlet flow, refrigerant, mass \\
FE3 & Chiller inlet flow, brine \\
FE4 & Brine pump discharge flow \\
FE5 & Compressor outlet flow, volume \\
FE6 & Condenser inlei water flow \\
JE1 & Compressor energy and power \\
JE3 & Brine pump energy and power \\
JE10 & Heater energy and power \\
PE1 & Compressor discharge pressure \\
PE2 & Condenser outlet refrigerant pressure \\
PE4 & Chiller inlet refrigerant pressure \\
PE5 & Chiller inlet refrigerant pressure \\
PE10 & Compressor suction pressure \\
TE1 & Compressor discharge temperature \\
TE2 & Condenser discharge temperature \\
TE4 & Chiller inlet refrigerant temperature \\
TE5 & Chiller inlet refrigerant temperature \\
TE10 & Compressor suction temperature \\
TE11 & Heater inlet water temperature \\
TE12 & Heater outlet water temperature \\
TE14 & Ice tank outlet brine temperature \\
TE15 & Ice tank outlet brine temperature \\
TE16 & Ice tank inlet brine temperature \\
TE17 & Chiller outlet brine temperature \\
TE18 & Chiller inlet brine temperature \\
TE19 & Condenser inlet water temperature \\
TE20 & Condenser outlet water temperature \\
\hline
\end{tabular}

valves exhibited a large degree of hunting during the beginning of most freeze tests. This is typical for part-loaded expansion valves, and the hunting usually stopped after $\sim 30$ to 45 min of operation. The brine pump speed was varied to control the brine flow rate at the selected value during the charge cycle.

The ISTF was designed to permit testing under a wide range of controlled conditions. Two parallel compressors with part-load capabilities are used to vary the chiller capacity from 15 to 95 tons. The flow of water to the condenser controls the condensing temperature between 80 and $100^{\circ} \mathrm{F}$. During discharge cycles, the brine pump speed, heater power, and bypass valve positions are used to control test conditions. 


\section{SYSTEM TESTS}

The test plan was structured to test the storage tank's capabilities under a wide range of operating conditions. The compressor discharge pressure and loading and the brine flow rate were the primary variables during the charging tests. The flow rate to the heater, heater power, and the brine temperature exiting the heater were the control variables during the discharge tests.

The test schedule was designed to show how the storage system would respond to different ice-charging periods (from 8 to $16 \mathrm{~h}$ ). The ice-discharge tests were designed to mimic different discharge periods ranging from 6 to $12 \mathrm{~h}$ with varying temperature and flow requirements at the heater. Tables 2-4 are taken from the ISTF test procedure and show the desired testing schedule. ${ }^{2}$ However, this procedure was in the process of revision during the Calmac tests. (Indeed, many revisions were prompted by experience gained during the Calmac tests.) Tables 5 and 6 present a summary of the tests that were used to analyze the Calmac storage system performance.

Many charging tests were run under compressor part-load conditions. Comparing actual power use to the compressor curve predictions for full-load power use underscores the

Table 2. Planned charge test sequence

\begin{tabular}{cccc}
\hline Test No. & $\begin{array}{c}\text { Test duration } \\
\text { (h) }\end{array}$ & $\begin{array}{c}\text { Refrigerant flow to } \\
\text { storage tank } \\
\text { (gal/min) }\end{array}$ & $\begin{array}{c}\text { Brine flow to } \\
\text { storage tank }^{\mathbf{b}} \\
\text { (gal/min) }\end{array}$ \\
\hline 1 & 6 & $\mathrm{MR}^{\mathrm{c}}$ & $\mathrm{MR}$ \\
2 & 6 & $1.25 \times \mathrm{MR}$ & $1.5 \times \mathrm{MR}$ \\
3 & 10 & $\mathrm{MR}$ & $\mathrm{MR}$ \\
4 & 14 & $\mathrm{MR}$ & $\mathrm{MR}$ \\
5 & 14 & $0.8 \times \mathrm{MR}$ & $0.5 \times \mathrm{MR}$ \\
6 & 18 & $\mathrm{MR}$ & $\mathrm{MR}$ \\
7 & 10 & $\mathrm{MR}$ & $2 \times \mathrm{MR}$ \\
8 & 6 & $\mathrm{MR}$ & $\mathrm{MR}$ \\
\hline
\end{tabular}

${ }^{a}$ Specified for liquid overfeed tests only.

${ }^{b}$ Specified for secondary loop tests only.

'Manufacturer's recommended flow rates. 
Table 3. Planned discharge test sequence

\begin{tabular}{cccc}
\hline Test No. & $\begin{array}{c}\text { Test duration } \\
(\mathrm{h})\end{array}$ & $\begin{array}{c}\text { TE12 } \\
\left({ }^{\circ} \mathrm{F}\right)\end{array}$ & $\begin{array}{c}\text { TE11 } \\
\left({ }^{\circ} \mathrm{F}\right)\end{array}$ \\
\hline 1 & 6 & 60 & 38 \\
2 & 9 & 60 & 45 \\
3 & 12 & 60 & 45 \\
4 & 6 & 50 & 38 \\
5 & 9 & 50 & 38 \\
6 & 12 & 50 & 45 \\
\hline
\end{tabular}

Table 4. Planned standby test sequence

\begin{tabular}{ccc}
\hline Test No. & $\begin{array}{c}\text { Test duration } \\
(\mathrm{h})\end{array}$ & Initial tank condition \\
\hline 1 & $>60$ & Fully frozen \\
2 & $>60$ & Fully frozen \\
\hline
\end{tabular}

high efficiency penalties associated with part-load operation. These penalties are discussed further in a companion document. ${ }^{3}$

Ice tank heat gains were measured by recording the change in ice inventory over a long period of time in the absence of all external fluid flows. The ice depletion over this time period was ascribed to shell heat gains. The ambient temperature was noted during the standby test. Because of the sheltered location of the test floor, the ambient conditions showed little variation. 
Table 5. Calmac charge test summary

\begin{tabular}{|c|c|c|c|c|}
\hline Test ID & $\begin{array}{l}\text { Average capacity based } \\
\text { on brine flow and } \\
\text { temperature change } \\
\text { (ton) }\end{array}$ & $\begin{array}{c}\text { Capacity ratio: brine } \\
\text { measurements/tank } \\
\text { water depth } \\
\text { measurements }\end{array}$ & $\begin{array}{c}\text { Brine flow } \\
\text { rate } \\
(\mathrm{gal} / \mathrm{min})\end{array}$ & $\begin{array}{c}\text { Average brine } \\
\text { temperature rise } \\
\text { across coils }{ }^{a} \\
\left({ }^{\circ} \mathrm{F}\right)\end{array}$ \\
\hline \multicolumn{5}{|c|}{$33 \%$ brine, water in tank } \\
\hline 0915 & 31 & $b$ & 67 & 11.7 \\
\hline 0919 & 30 & 0.88 & 60 & 12.5 \\
\hline 0921 & 18 & 0.84 & 40 & 11.5 \\
\hline 0925 & 26 & 0.92 & 60 & 11.0 \\
\hline 0928 & 18 & 0.85 & 80 & 5.7 \\
\hline 0929 & 20 & 0.89 & 60 & 8.2 \\
\hline 1003 & 15 & 0.88 & 40 & 9.5 \\
\hline 1005 & 19 & 0.83 & 60 & 7.8 \\
\hline 1006 & 19 & 0.83 & 60 & 7.8 \\
\hline 1010 & 10 & $b$ & 46 & 5.7 \\
\hline \multicolumn{5}{|c|}{$25 \%$ brine, water in tank } \\
\hline 1026 & 17 & 0.82 & 59 & 7.2 \\
\hline 1030 & 9 & 1.23 & 60 & 3.6 \\
\hline 1103 & 8 & 1.12 & 59 & 3.5 \\
\hline 1108 & 14 & 1.22 & 70 & 5.0 \\
\hline 0214 & 8 & 1.19 & 54 & 3.9 \\
\hline 0216 & 20 & 1.20 & 67 & 7.4 \\
\hline \multicolumn{5}{|c|}{$33 \%$ brine, eutectic in tank } \\
\hline 0116 & 13 & $c$ & 40 & 3.4 \\
\hline 0119 & 17 & $c$ & 60 & 4.8 \\
\hline 0123 & 8 & $c$ & 60 & 8.3 \\
\hline 0126 & 15 & $c$ & 80 & 7.1 \\
\hline
\end{tabular}

${ }^{a} \mathrm{RTD}$ specification of $\pm 0.5^{\circ} \mathrm{F}$.

${ }^{b}$ Not available.

${ }^{c}$ Not available. 
Table 6. Calmac discharge test summary ${ }^{a}$

\begin{tabular}{|c|c|c|c|c|}
\hline Test ID & $\begin{array}{c}\text { Average capacity } \\
\text { based on brine flow } \\
\text { and temperature } \\
\text { change at tank } \\
\text { (ton) }\end{array}$ & $\begin{array}{c}\text { Temperature } \\
\text { to load } \\
\left({ }^{\circ} \mathrm{F}\right)\end{array}$ & $\begin{array}{c}\text { Temperature } \\
\text { out load }^{c} \\
\left({ }^{\circ} \mathrm{F}\right)\end{array}$ & $\begin{array}{l}\text { Average brine } \\
\text { flow to tank } \\
\text { (gal/min) }\end{array}$ \\
\hline \multicolumn{5}{|c|}{$33 \%$ brine, water in tank } \\
\hline 0920 & 41 & 38 & 50 & 85 \\
\hline 0925 & 42 & 48 & 60 & 59 \\
\hline 0926 & 37 & 44 & 50 & 84 \\
\hline 0927 & 28 & 44 & 50 & 61 \\
\hline 1002 & 36 & 40 & 60 & 46 \\
\hline 1009 & 14 & 42 & 60 & 15 \\
\hline 1011 & 21 & 36 & 60 & 22 \\
\hline \multicolumn{5}{|c|}{$25 \%$ brine, water in tank } \\
\hline 1101 & 13 & 42 & 60 & 15 \\
\hline 1110 & 20 & 36 & 60 & 21 \\
\hline 0213 & 20 & 44 & 50 & 40 \\
\hline 0215 & 20 & 47 & 60 & 21 \\
\hline \multicolumn{5}{|c|}{$25 \%$ brine, eutectic in tank } \\
\hline 0111 & 12 & 42 & 60 & $d$ \\
\hline \multicolumn{5}{|c|}{$33 \%$ brine, eutectic in tank } \\
\hline 0118 & 22 & 38 & 60 & 21 \\
\hline 0122 & 13 & 38 & 50 & 21 \\
\hline 0125 & 24 & 45 & 50 & 34 \\
\hline 0129 & 27 & 45 & 50 & 43 \\
\hline
\end{tabular}

${ }^{a}$ Data for test up until tank outlet temperature exceeds $48^{\circ} \mathrm{F}$ or until heater outlet temperature exceeds control value, whichever occurs first.

${ }^{b}$ Controlled at the given value until tank outlet temperature exceeds this value. Test then continues until heater outlet temperature is exceeded.

${ }^{c}$ Controlled value.

${ }^{d}$ Unavailable. 


\section{ANALYSIS METHODOLOGY}

The primary concern of the data analysis is to produce useful information and to present it in a meaningful fashion. Another concern is to distinguish between the performance of the ice storage system and the performance of the refrigeration system. While analysis of the refrigeration system performance can prove enlightening and is certainly useful to system designers, it must be distinguished from that of the manufacturer's storage system. Also, the test facility is different from a commercial system because it must have the flexibility to test a wide variety of system types. This introduces much added complexity that a commercial system would not encounter.

\subsection{DATA PROCESSING}

The data available for each operational test permit redundant calculations that increase our understanding and confidence in the test results. For example, the heat rejection at the condenser is measured on both the water and refrigerant sides of the heat exchanger. The refrigeration effect to the ice tank is measured by both changes in the water height (a measure of the ice inventory) and by the brine flow and temperature change. The refrigeration effect is also measured at the chiller on both the brine and refrigerant sides. The energy available for discharge is measured by brine flow and temperatures at the heater and at the ice tank, as well as by the power going to the discharge heater. This duplication of measurements also enables us to more fully separate the performance of the ice storage system from that of the refrigeration system.

The data are collected for each monitoring point every $30 \mathrm{~s}$ during a charge test and every $15 \mathrm{~s}$ during a discharge test. This collection frequency is dictated by system control requirements rather than by the analysis requirements. The data are immediately summed (for flows or energy uses) or averaged (for temperatures, pressures, power uses, and flow rates) to represent the appropriate values on a 5 -min basis.

Thermodynamic properties for R-22 are calculated from a computerized format developed by G. T. Kartsounes and R. A. Erth and adapted for use at Oak Ridge National Laboratory (ORNL) by C. K. Rice and S. K. Fischer. ${ }^{4}$ Brine properties, as a function of concentration and temperature, were provided by Union Carbide Corporation, and information for the temperature range of interest was extracted. 5 


\subsection{REFRIGERATION EFFECT}

\subsubsection{Storage Tank}

The refrigeration effect in the ice tank is directly measured by recording the depth of the water in the tank, as was described in Sect. 3. This measurement is reliable whenever ice is present in the tank and when the ice is submerged, usual conditions during a charging cycle. The measured density of ice in previous local tests was $57.2 \mathrm{lb} / \mathrm{ft}^{3}$, in good agreement with the reported range of $57.2 \mathrm{lb} / \mathrm{ft}^{3}$ at $0^{\circ} \mathrm{C}$ to $57.4 \mathrm{lb} / \mathrm{ft}^{3}$ at $-10^{\circ} \mathrm{C}$ (Ref. 6). The measured volume change vs tank depth change in the 7 in. above the fully filled level was $21.1 \mathrm{gal} / \mathrm{in}$. These figures, combined with an assumed water density of $62.4 \mathrm{lb} / \mathrm{ft}^{3}$ and the heat of fusion of $144 \mathrm{Btu} / \mathrm{lb}$, produce a latent storage capacity of 23.2 ton-h/in. change in water depth.

The heat of fusion and density of the eutectic were not experimentally measured during the tests at the ISTF. Calmac reports that the overall tank capacity should be derated by $15 \%$ when the $28^{\circ} \mathrm{F}$ eutectic is used. ${ }^{7}$ Using this factor, the latent storage capacity was taken to be 19.7 ton-h/in. change in eutectic depth.

The stored cooling effect is also calculated from the measured hrine flow rate and temperature gain as is shown in Eq. (1).

$$
\mathrm{RE}_{\mathrm{b}}=\mathrm{FE} 4 \times \mathrm{c}_{\mathrm{p}} \times \rho \times(\mathrm{TE} 15-\mathrm{TE} 16)
$$

where

$$
\begin{aligned}
\mathrm{RE}_{\mathrm{b}} & =\text { refrigeration effect measured by the brine, } \\
\mathrm{FE} 4 & =\text { brine flow from the chiller, } \\
\mathrm{c}_{\mathrm{p}} & =\text { brine specific heat, } \\
\rho & =\text { brine density, } \\
\mathrm{TE} 15 & =\text { brine temperature leaving the ice tank, } \\
\mathrm{TE} 16 & =\text { brine temperature entering the ice tank. }
\end{aligned}
$$

The brine specific heat and specific gravity are provided in the form of families of curves in Ref. 5. Interpolations from these curves for the temperature range from 20 to $60^{\circ} \mathrm{F}$ and a brine concentration of $33 \mathrm{wt} \%$ produced the following equations for specific gravity (relative to water at $60^{\circ} \mathrm{F}$ ) and specific heat.

$$
\mathrm{SG}=(-0.0002) \times \mathrm{T}+1.063
$$


where

$$
\begin{aligned}
\mathrm{SG} & =\text { specific gravity } \\
\mathrm{T} & =\text { average brine temperature }\left({ }^{\circ} \mathrm{F}\right) .
\end{aligned}
$$

$$
c_{p}=0.0003 \times T+0.899
$$

where

$$
\begin{aligned}
\mathbf{c}_{\mathrm{p}} & =\text { specific heat }\left[\mathrm{Btu} /\left(\mathrm{lb}-{ }^{\circ} \mathrm{F}\right)\right] \\
\mathrm{T} & =\text { average brine temperature }\left({ }^{\circ} \mathrm{F}\right)
\end{aligned}
$$

Interpolation for a brine concentration of $25 \mathrm{wt} \%$ produced Eqs. (4) and (5).

$$
\begin{gathered}
S G=(-0.000108) \times T+1.0482 \\
c_{p}=0.000275 \times T+0.922
\end{gathered}
$$

The system capacity was also measured at the evaporator/chiller, on both the brine and refrigerant sides. These measurements provide another checkpoint to guard against instrument failure. The capacity measured at the chiller is expected to be slightly higher than that at the ice tank due to shell heat gains at the tank and in the piping and also by the amount of energy added by the brine pumps. The brine-side measurements are similar to those used for the ice tank and are shown in Eq. (6). The refrigerant-side measurements are used in Eq. (7). Shell losses from the well-insulated chiller are assumed to be negligible.

$$
\mathrm{RE}_{\mathrm{bch}}=\mathrm{FE} 4 \times \mathrm{c}_{\mathrm{p}} \times \rho \times(\mathrm{TE} 18-\mathrm{TE} 17)
$$

where

$\begin{aligned} \mathrm{RE}_{\mathrm{bch}}= & \begin{array}{l}\text { refrigeration effect at the chiller, based on brine flow and temperature } \\ \text { measurements, }\end{array}\end{aligned}$ FE4 = brine flow from the chiller,

$c_{p}=$ brine specific heat,

$\rho=$ brine density,

TE17 = brine temperature leaving the chiller,

TE18 = brine temperature entering the chiller.

$$
\mathrm{RE}_{\mathrm{fch}}=\mathrm{FE} 1 \times(\mathrm{HE} 10-\mathrm{HE} 2)
$$


where

$\mathrm{RE}_{\mathrm{fch}}=$ refrigeration effect at the chiller, based on refrigerant flow and property measurements,

FE1 = refrigerant flow to the chiller,

HE10 = enthalpy corresponding to the measured suction temperature and pressure of the superheated refrigerant leaving the chiller,

HE2 = enthalpy corresponding to the saturated liquid refrigerant leaving the condenser.

\subsubsection{Refrigeration System}

Another measurement of the system capacity can be taken from the compressor curves. These curves were modeled by Eqs. (8)-(11). Equation (8) predictions match the compressor manufacturer's table within \pm 0.5 ton. Equation (10) predictions match the manufacturer's table within $\pm 0.5 \mathrm{hp}$. The heat of rejection model, Eq. (11), has residuals ranging from -0.005 to +0.016 . Many tests were run at part-load conditions; that is, the compressor was not operating at full capacity. The compressor capacity and heat rejection predictions were therefore reduced in proportion to the loading on the compressor. The manufacturer's power consumption table is good only for fully loaded conditions and cannot accurately predict part-load power requirements.

$$
\begin{gathered}
\mathrm{Re}_{\mathrm{c}}=49.35+1.663 \times \mathrm{T}_{\mathrm{s}}-0.00173 \times\left(\mathrm{T}_{\mathrm{d}}\right)^{2} \\
-0.00708 \times \mathrm{T}_{\mathrm{s}} \times \mathrm{T}_{\mathrm{d}}+0.00953 \times\left(\mathrm{T}_{\mathrm{s}}\right)^{2} \times \mathrm{C}_{\mathrm{s}} \\
\mathrm{C}_{\mathrm{s}}=1+0.0005 \times\left(\mathrm{T}_{\mathrm{d}}-\mathrm{TE} 2-15\right), \\
\dot{\mathrm{W}}_{\mathrm{c}}=44.088-0.508 \times \mathrm{T}_{\mathrm{s}}+0.000840 \times\left(\mathrm{T}_{\mathrm{d}}\right)^{2} \\
+0.0123 \times \mathrm{T}_{\mathrm{s}} \times \mathrm{T}_{\mathrm{d}}-0.00592 \times\left(\mathrm{T}_{\mathrm{s}}\right)^{2}, \\
\dot{\mathrm{Q}}_{\mathrm{c}}=1.090-0.00422 \times \mathrm{T}_{\mathrm{s}}+0.00263 \times \mathrm{T}_{\mathrm{d}},
\end{gathered}
$$

where

$$
\begin{aligned}
\operatorname{Re}_{c} & =\text { refrigeration capacity predicted by the compressor capacity curves (tons), } \\
T_{s} & =\text { saturated suction temperature }\left({ }^{\circ} \mathrm{F}\right) \\
T_{d} & =\text { saturated discharge temperature }\left({ }^{\circ} \mathrm{F}\right) \\
\mathrm{C}_{\mathrm{s}} & \left.=\text { capacity correction for subcooling (table based on } 15^{\circ} \mathrm{F}\right)
\end{aligned}
$$




$$
\begin{aligned}
& \dot{\mathrm{W}}_{\mathbf{c}}=\text { compressor power predicted by the manufacturer's data (bhp), } \\
& \dot{\mathbf{Q}}_{\mathbf{c}}=\text { heat of rejection predicted by the compressor manufacturer (ton). }
\end{aligned}
$$

As another check on the system, the heat rejected at the condenser is measured on both the refrigerant and water sides [see Eqs. (12) and (13)].

$$
\begin{gathered}
\dot{\mathrm{Q}}_{\mathrm{w}}=\text { FE6 } \times(\text { TE20 }- \text { TE19), } \\
\dot{\mathrm{Q}}_{\mathrm{q}}=(\text { FE5/VE1 }) \times(\mathrm{HE} 1-\mathrm{HE} 2),
\end{gathered}
$$

where

$$
\begin{aligned}
\dot{\mathrm{Q}}_{\mathrm{w}} & =\text { heat absorbed by the cooling water, } \\
\mathrm{FE} 6 & =\text { water flow rate, } \\
\mathrm{TE} 20 & =\text { water temperature into the condenser, } \\
\mathrm{TE} 19 & =\text { water temperature exiting the condenser, } \\
\dot{\mathrm{Q}} & =\text { heat rejected by the refrigerant, } \\
\mathrm{FE} 5 & =\text { refrigerant volume flow entering the condenser, } \\
\mathrm{VE} 1 & =\text { refrigerant specific volume entering the condenser, } \\
\mathrm{HE} 1 & =\text { refrigerant enthalpy entering the condenser, and } \\
\mathrm{HE} 2 & =\text { refrigerant enthalpy leaving the condenser. }
\end{aligned}
$$

\subsubsection{Capacity Models and Capacity Normalization}

A normalized capacity is also calculated to provide a clearer picture of the change in capacity during the charging cycle. The capacity at each point in time is divided by the average capacity over the entire charging test period (not including the cooldown portion of the test). The normalization is only accurate for those tests that extend from the fully melted to the fully frozen states.

A mathematical model was also created to represent the capacity as a function of the state of charge for each point in time during the test. Several models were tested using the SAS Institute, Inc., system procedure entitled REG. ${ }^{8}$ This procedure fits least-squares estimates to linear regression models and reports the adjusted squared correlation coefficient as well as the Student's $T$ ratio and significance probability for each parameter estimate. Based on these model evaluation points, the best model was chosen and is shown in Eq. (14). The predicted values were plotted vs the residual values to check for unwanted trends in the 
model outpui. The modeling process smooths out the irregularities present in most test data and makes it easier to identify trends in the data. The use of this model is explained more clearly in the results section.

$$
\mathrm{Re}_{\mathrm{bn}}=A_{1}+A_{2} \times P D E 1+A_{3} \times(D P D E 1)^{2}+A_{4} \times(D P D E)^{1 / 2}
$$

where

$$
\begin{aligned}
\mathrm{Re}_{\mathrm{bn}} & =\text { capacity, normalized relative to the average capacity, } \\
\mathrm{A}_{1}-\mathrm{A}_{4} & =\text { parameier coefficients that are different for each test, } \\
\mathrm{PDE} 1 & =\text { tank water depth, } \\
\mathrm{DPDE} 1 & =\begin{array}{l}
\text { difference between the tank water depth and the fully melted tank water } \\
\text { depth. }
\end{array}
\end{aligned}
$$

\subsection{DISCHARGE ENERGY AVAILABLE}

The cool storage available to meet a cooling load was measured by the brine flow rates and temperature changes at the heater and at the ice tank [see Eqs. (15) and (16)]. The tank storage inventiry is not measurable during the discharge cycle because there is no way of measuring the mixed temperature of the liquid water within the storage sank. This water is increasing in temperature throughout the test. However, the initial amount of available cool storage is calculated based on the tank water height (at 23.2 ton-h/in.) and the initial temperature of the brine in the piping outside the tank (assuming that the brine inventory within the tank is at $32^{\circ} \mathrm{F}$ ). The cool storage depletion from this initial value as measured at the tank wiil differ from the cooling delivered to the load by the amount of the pump work on the iluid and the standby losses from the tank walls.

$$
\begin{aligned}
& \text { car }_{\mathrm{t}}=\text { FE4 } \times(\text { TE12 }- \text { TE11 }) \times c_{p} \times \rho, \\
& \text { cap }_{t}=\text { FE3 } \times(\text { TE15 }- \text { TE16 }) \times c_{p} \times \rho,
\end{aligned}
$$

where

$$
\begin{aligned}
\text { cap }_{\mathrm{b}} & =\text { discharge capacity measured at the heater } \\
\mathrm{FE} 4 & =\text { brine flow to heater, } \\
\mathrm{TE} 12 & =\text { brine temperature leaving heater, } \\
\mathrm{TE} 11 & =\text { brine emperature entering heater, }
\end{aligned}
$$


$c_{p}=$ specific heat of brine,

cap $_{\mathbf{t}}=$ discharge capacity measured at the ice tank,

FE3 = brine flow to ice tank,

TE15 = brine temperature leaving ice tank,

TE16 = brine temperature to ice tank,

$\rho=$ brine density.

The heater power was also measured but is not considered accurate as is discussed in Appendix A. Corrections were also made to the calculated cumulative discharge to account for standby losses that occurred whenever a test was stopped and then restarted the next day. The tank was considered to be fully discharged when the tank outlet temperature reached $48^{\circ} \mathrm{F}$. Some ice may remain in the tank at that time but is unavailable to meet the load.

\subsection{SHELL HEAT GAINS}

Shell heat gains were measured directly from changes in tank water depth over extended periods of time when there was no external flow. 


\section{RESULTS}

The tests were run at two brine concentrations, 33 and $25 \%$, both by weight. The higher brine concentrations were necessary to avoid freezing brine in the chiller/evaporator during the high-capacity tests. The lower brine concentration tests were made to provide test data at Calmac's recommended concentration.

The brine pressure drop across the Calmac coils was measured at flow rates of 20,40 , $60,70,80$, and $90 \mathrm{gal} / \mathrm{min}$, with the $33 \mathrm{wt} \%$ brine mixture. The measured pressure drop ranged from 0.2 psi less to 0.6 psi more than the values presented by Calmac; ${ }^{1}$ they range from $2 \mathrm{psi}$ at $20 \mathrm{gal} / \mathrm{min}$ to $15.6 \mathrm{psi}$ at $90 \mathrm{gal} / \mathrm{min}$. A friction factor correlation shows that the pressure drop is approximately proportional to the Reynold's number raised to the -0.25 power. 9 Based on this correlation, pressure losses at the recommended brine concentration of $25 \mathrm{wt} \%$ should be $\sim 5 \%$ less than the measured values and produce pressure drops in very close agreement to the values reported by Calmac.

Calmac also offers an insertion probe and inventory meter for use in monitoring the ice in the tank. These work by measuring the increase in tank height that occurs when ice (with a lower density than the surrounding water) is formed. The insertion probe is supplied with an air pump to continuously bubble air through the line and prevent ice plugs from forming. This strategy was successful during the testing period except when testing the eutectic mixture with a depressed freezing point of $28^{\circ} \mathrm{F}$. During these eutectic tests with lower temperatures, ice plugs from 1 to 5 in. in length were formed. These plugs had to be manually removed from the probe. The voltage output of the probe was found to be linearly proportional to the tank height during both charge and discharge cycles. Therefore, although the Calmac meter depth reading varied from 0.1 to $0.2 \mathrm{in}$. higher than that recorded by our own instrumentation and visual readings, it was relatively stable and repeatable.

\subsection{CHARGING PERFORMANCE}

When designing a thermal storage system for a given application, the heat rejection temperature, storage capacity, and time available for charging are usually known. ${ }^{10}$ This establishes the average capacity needed during the charging cycle. The ability of a storage system to meet these requirements is a function of both the storage tank/coil design and of the balance of the refrigeration system, most importantly the compressor. 
Compressor manufacturers present their capacity as a function of saturated suction and discharge temperatures (Sect. 4.2 described the manufacturer's data for the ISTF compressor). When charging an ice-on-coil storage tank, the suction temperature gradually drops as the water in the tank becomes colder and ice builds up on the coils. The reduced suction temperature leads to a reduced refrigeration capacity. The temperature profile of the fluid entering the tank vs the tank state of charge is therefore an important characteristic of the storage system.

Capacity calculations were described in Sect. 4.2 and are based on an energy balance on the ice tank. The cumulative value of this calculated refrigeration capacity (based on the brine flow rate and temperature change in the ice tank) was compared to the change in storage tank depth. This comparison is shown in Table 5 as the capacity ratio. This ratio represents the cumulative capacity based on brine measurements divided by the cumulative capacity based on the change in tank water depth. This ratio varies from a low of 0.82 to a high of 1.23. This means that the capacity, as calculated from the brine flow and temperature change, varied from $18 \%$ less to $23 \%$ more than the capacity as measured by the amount of ice manufactured.

This discrepancy was investigated by examining the data, test log notes, and instrument calibration records. The resistance temperature detectors (RTDs) were calibrated before the first Calmac test, and three RTDs were replaced. Although this initial calibration was not recorded, any RTD that was more than $\pm 0.5^{\circ} \mathrm{F}$ from the ice bath temperature would have been changed. The RTDs were again checked in an ice bath on September 26, and the measurement at the tank outlet was found to be $0.3^{\circ} \mathrm{F}$ higher than the one at the tank inlet. This was within the specified accuracy band, and no changes were made. On October 16, the RTD at the tank inlet measured a temperature $0.1^{\circ} \mathrm{F}$ high, and the tank outlet was $0.2^{\circ} \mathrm{F}$ low, for an error in the difference of $0.3^{\circ} \mathrm{F}$ (negative during a charge and positive during a discharge). For a charge test with a $12^{\circ} \mathrm{F}$ change across the brine coils, this $0.4^{\circ} \mathrm{F}$ error would cause the capacity to be underestimated by $3 \%$. For a test with a $3.5^{\circ} \mathrm{F}$ change across the brine coils, this $0.4^{\circ} \mathrm{F}$ error would cause the capacity to be underestimated by $12 \%$. (The average brine temperature change is shown in the last column of Table 5.) On February 6, 1990, the RTD at the coil outlet was again checked against an ice bath and found to be within $\pm 0.1^{\circ} \mathrm{F}$. On March 2, 1990, the RTDs at both the inlet and outlet were checked in a controlled temperature bath at 60 and $32^{\circ} \mathrm{F}$. The coil inlet RTD was $0.1^{\circ} \mathrm{F}$ high at both 60 and $32^{\circ} \mathrm{F}$. The coil outlet RTD was $0.2^{\circ} \mathrm{F}$ low at $60^{\circ} \mathrm{F}$ and $0.4^{\circ} \mathrm{F}$ low at $32^{\circ} \mathrm{F}$. If this 
condition was the same for the test on February 16, 1990 (test 0216), with an average measured temperature change of $7.4^{\circ} \mathrm{F}$, the capacity would have been underestimated by $7 \%$. However, as Table 5 shows, the brine measurements predicted 20\% more ice than was estimated using the water depth measurements.

Other possible sources of error are the brine flow measurement and the ice inventory measurement. The flowmeters have always shown good accuracy (to within 1\%) during calibration tests. Also, there are two flowmeters in series that showed close agreement throughout the test series.

The ice inventory measurement is based on the difference in density between water and ice, as was discussed in Sect. 4.2. Because not all the water in the tank is frozen during a full charge, the expected volume change is $8 \%$, or an increase of $\sim 130$ gal from an initial volume of $1620 \mathrm{gal}$. This volume change is detected by measuring the depth of the water in the tank. This measurement was done with a very simple arrangement of a tube submerged in the water near the top of the tank and luoped outside the tank to a ruler and a differential pressure transducer. The submerged tube was regularly checked to be sure it was clear of ice. This measurement was accurate to within $0.1 \mathrm{in}$. During a full charge, the change in tank depth would be -6 in., so the depth measurement would be accurate to within $\sim 2 \%$. Occasionally, a small amount of ice would be above the water, but this was not typical of normal operation. However, it is possible that the configuration of this storage tank could cause small air pockets to form and thereby elevate the water level, overstating the amount of ice within the tank. It is also possible that there could be some slight distortion of the side walls or that the plastic tubing within the tank could be compressed somewhat in a tank whose contents aré frozen nearly solid, thereby depressing the water level, and understating the amount of ice within the tank. Considering, however, that the capacity based on the ice inventory is both greater than (tests 0919-1026) and less than (tests 1030-0216) the capacity based on the brine flow and temperature change, the presence of such air pockets or tank distortions is not a likely cause of the noted discrepancies.

Based on these considerations, the amount of charge reflected by the change in tank depth was judged to be more reliable than that based on the brine flow and temperature change. The tank depth was therefore used to establish the initial charge level for all discharge tests.

The brine charge tests are summarized in Figs. 2 and 3. Figure 2 shows the capacity, as measured by the brine flow and temperature change across the storage tank coils, of all 


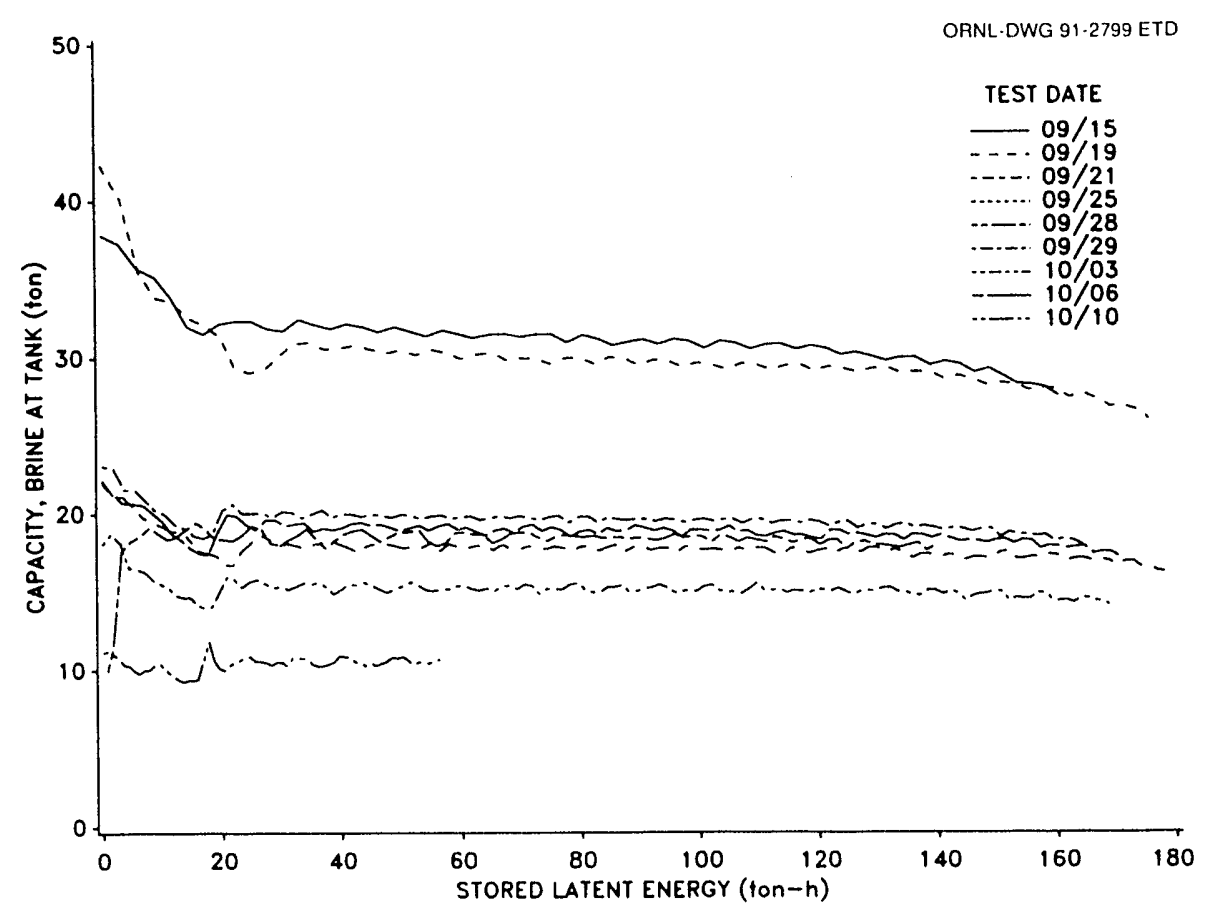

Fig. 2. Summary of Calmac charge tests with water in tank and brine concentration of $33 \%$, both capacity and stored latent energy based on brine temperature and flow measurements. All temperature measurements are $\pm 0.5^{\circ} \mathrm{F}$.

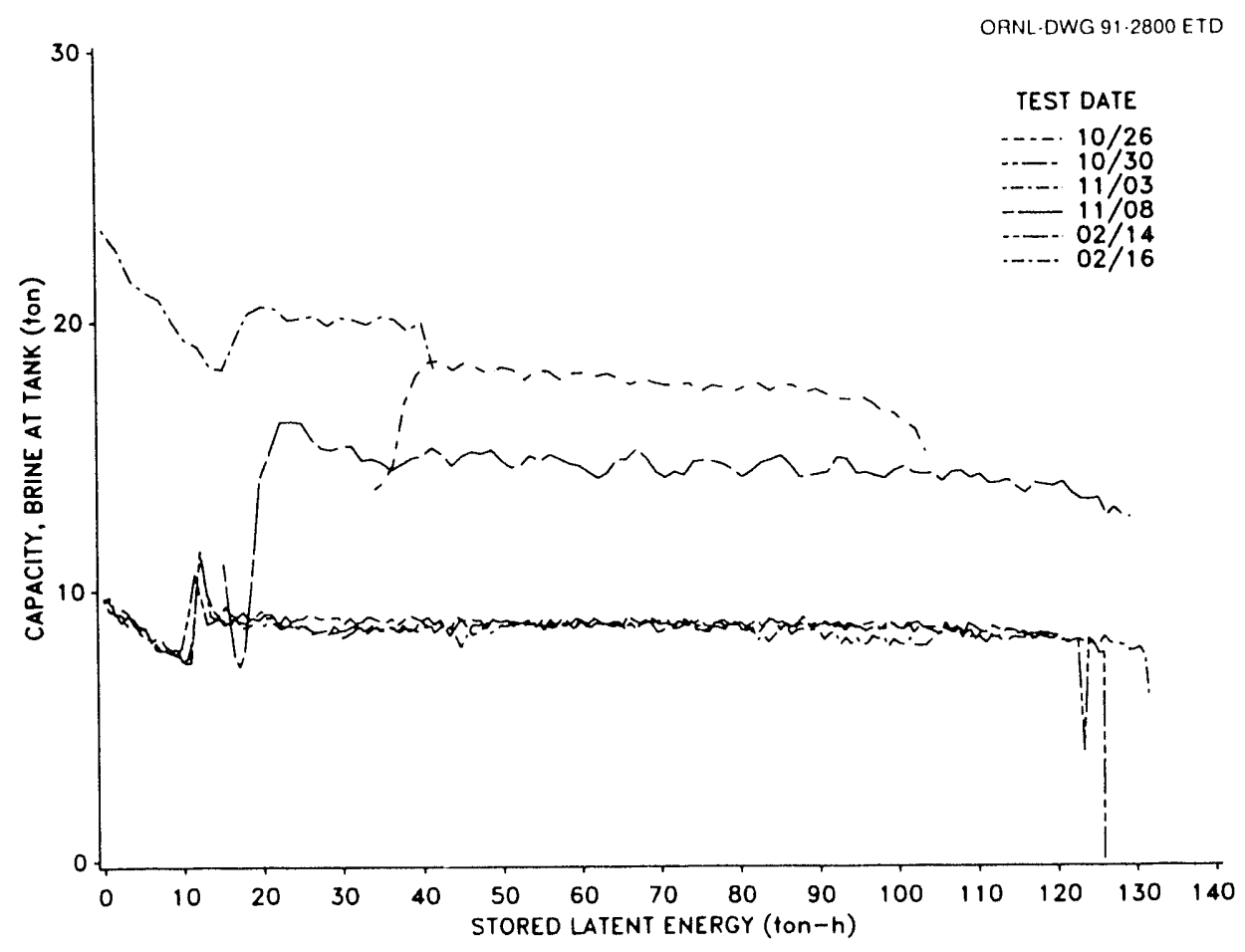

Fig. 3. Summary of Calmac charge tests with water in tank and brine concentration of $25 \%$, both capacity and stored latent energy based on brine temperature and flow measurements. All temperature measurements are $\pm 0.5^{\circ} \mathrm{F}$. 
tests that were made with a brine concentration of $33 \%$ (by weight). The stored latent energy is calculated by summing the calculated capacity during the test after the brine inlet temperature drops below $32^{\circ} \mathrm{F}$. Figure 3 gives this same data for tests that were made with a brine concentration of $25 \%$. The tests ranged in average capacities from 8 to 31 tons. Four of the tests shown in Fig. 3, 1030, 1103, 1108, and 0214, appear to stop short of a full charge. However, these tests actually did achieve a full charge as measured by the change in tank height. The capacity appears to be relatively insensitive to tank state of charge, with only a slight drop in capacity as the test nears completion.

The examine this issue more closely, a normalized capacity was calculated to show the decrease in capacity that cccurs as ice builds up around the coils within the storage tank. All the tests shown in Fig. 4 extended from essentially 0 to $100 \%$ charged and ranged from 15 to 30 tons. Because the roughness introduced by the capacity fluctuations makes this plot difficult to read, mathematical models of the capacity were used to generate the smoother normalized capacity curves of Fig. 5 as was discussed in Sect. 4. The curves are based on a functional relationship between the normalized capacity and the tank state of charge. The relationships for three of the tests, 0929,1003 , and 1006 , are relatively weak and explain only $\sim 70 \%$ of the variation in capacity during the test. The relationships for the other three tests are much stronger and explain $\sim 90 \%$ of the capacity variation. The T-test results for the parameter estimates were $>0.99$ for all estimates. It is therefore reasonable to use Fig. 5 to evaluate the limits and shape of the normalized capacity as a function of the tank state of charge. All the tests seem to start at a capacity $\sim 20$ to $25 \%$ greater than the test's average capacity, and all seem to reach the average when the tank is $\sim 20 \%$ charged. The capacity then shows little variation until the tank is about $70 \%$ charged, when the capacity begins to decrease, ending at $\sim 90$ to $95 \%$ of the average value. The average capacity, or charging time, appears to have only a moderate effect on the amount of derating and almost no effect on the shape of the normalized capacity curve.

The decrease in capacity during a charge cycle is caused by the reduction in saturated suction temperature at the compressor. This reduction is caused by the increased thermal resistance of the ice layer building on the heat exchanger tubes, which causes lower brine temperatures in the evaporator/chiller. The temperature of the brine entering the ice tank is shown in Figs. 6 and 7 for the 33\% and the $25 \%$ brine, respectively. At the flow rates used for these tests, laminar flow is present within the tubing. The Union Carbide Corporation provides heat transfer coefficients for brine mixtures as a function of brine concentration and 


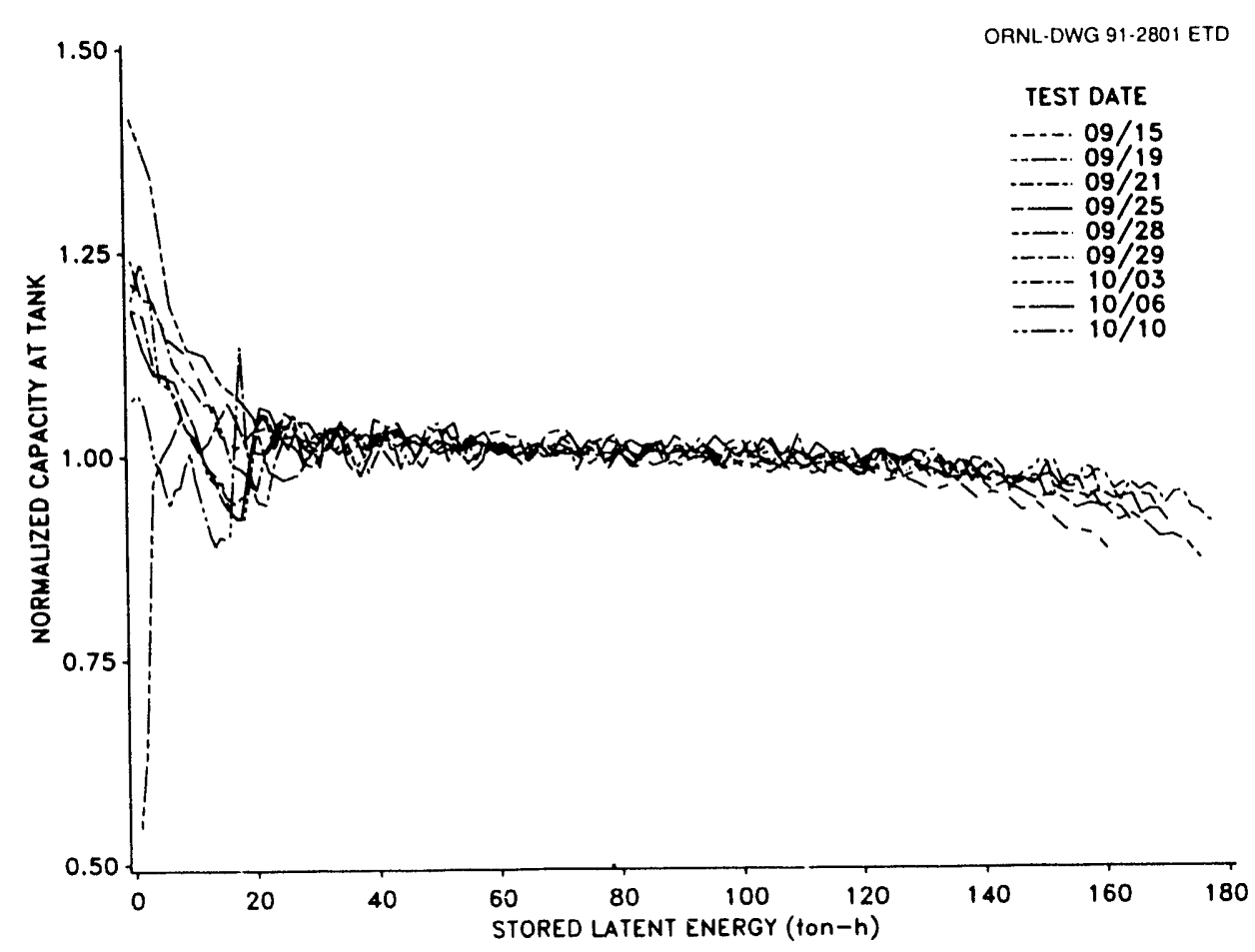

Fig. 4. Normalized capacity of Calmac charge tests with water in tank and brine concentration of $33 \%$, normalized relative to average for each test.

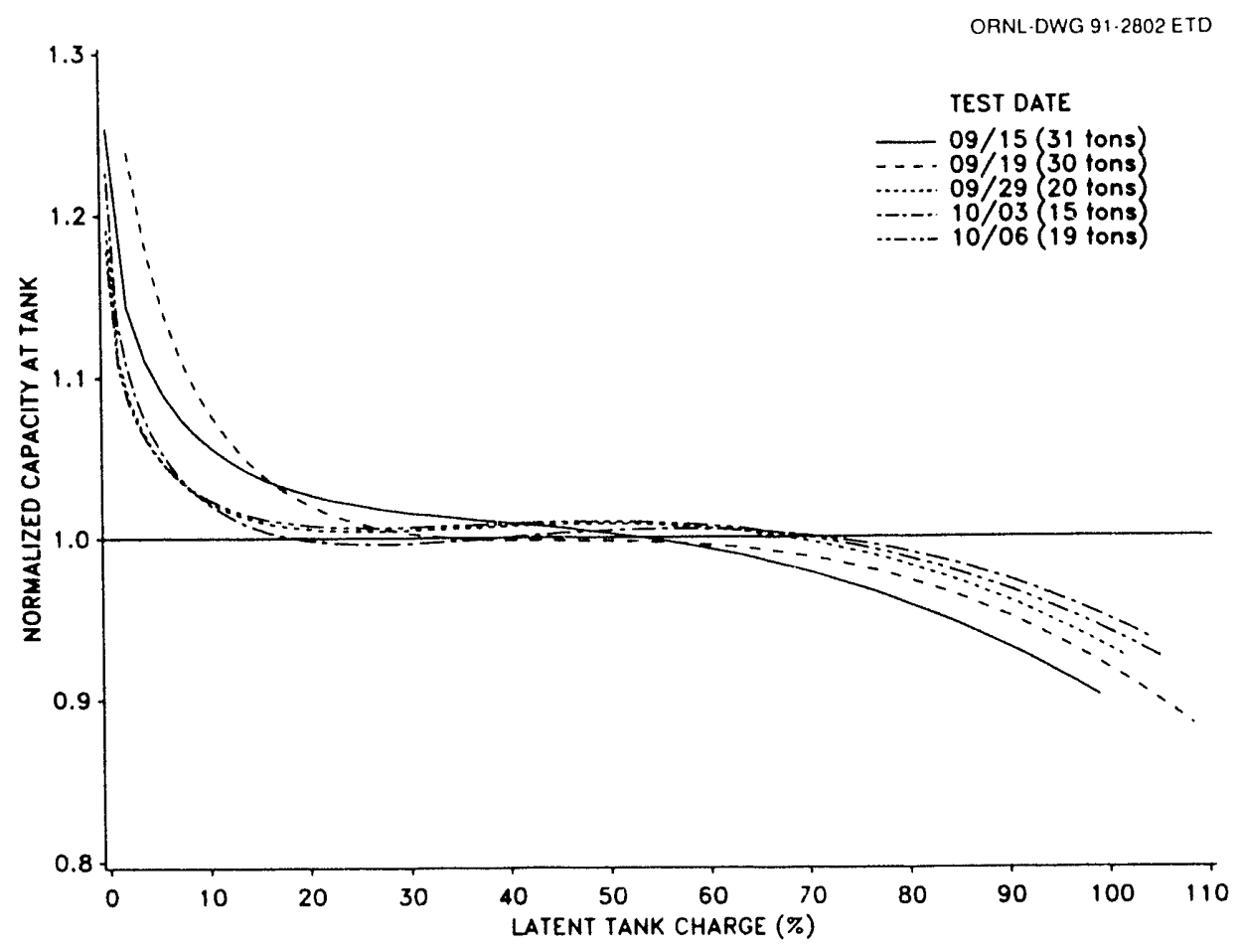

Fig. 5. Normalized capacity of Calmac charge tests with water in tank and brine concentration of $33 \%$, generated by test-specific mathematical models of normalized capacity as function of tank charge, normalized relative to average for each test. 


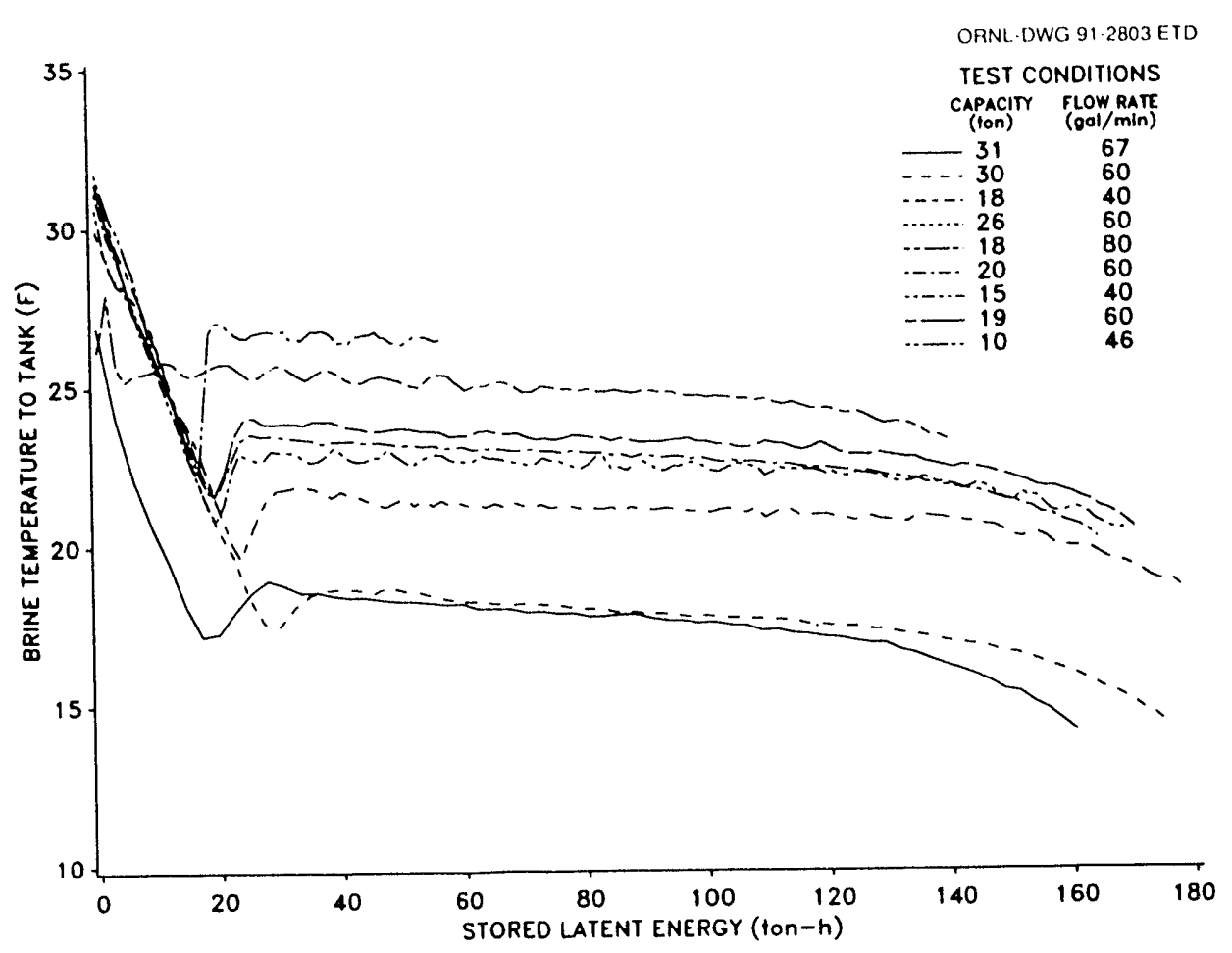

Fig. 6. Summary of tank brine inlet temperature profiles for all Calmac charge tests with water and brine concentration of $33 \%$. All temperature measurements are $\pm 0.5^{\circ} \mathrm{F}$.

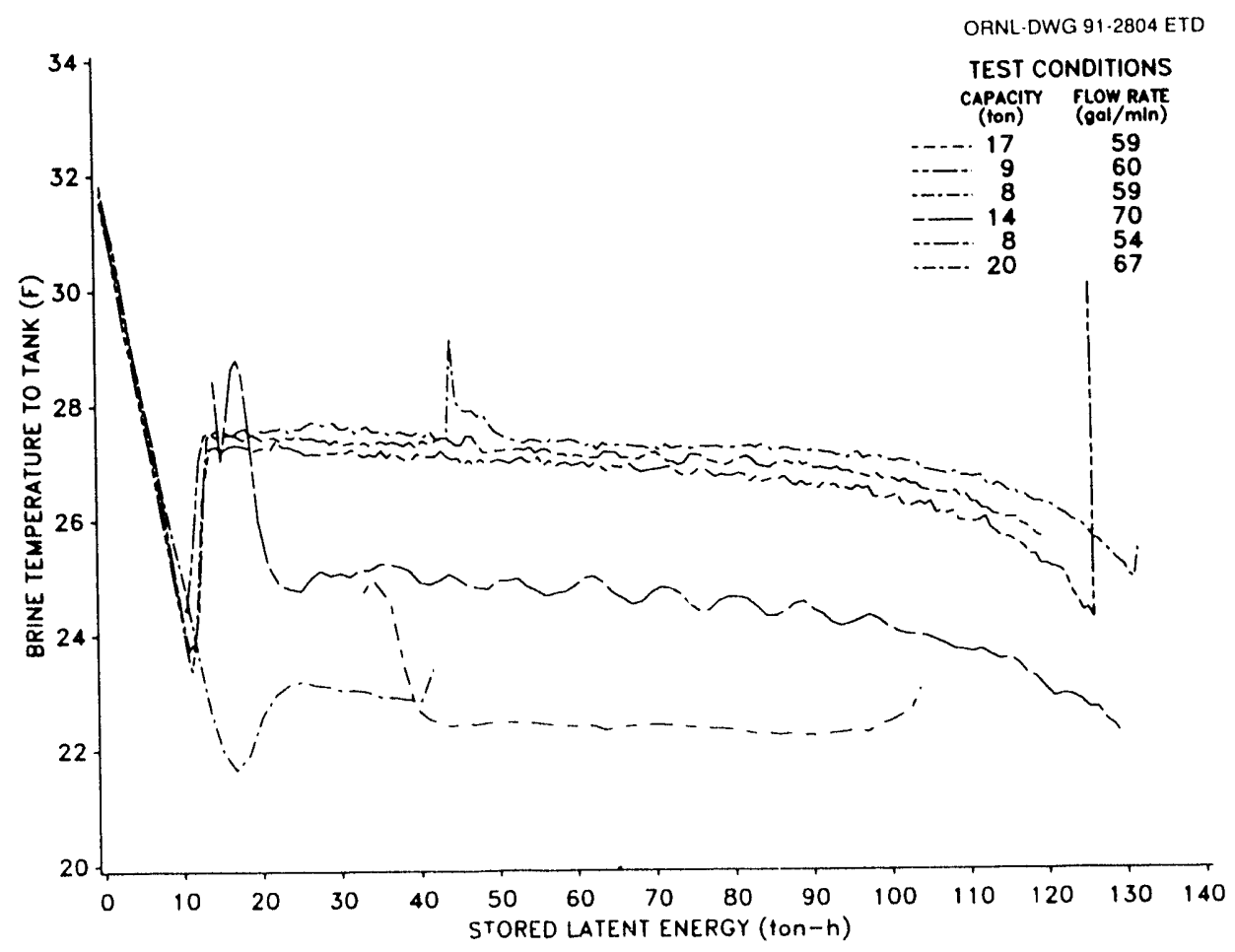

Fig. 7. Summary of tank brine inlet temperature profiles for all Calmac charge tests with water and brine concentration of $25 \%$. All temperature measurements are $\pm 0.5^{\circ} \mathrm{F}$. 
Reynolds number. ${ }^{5}$ For equivalent volumetric brine flow rates, the heat transfer coefficient for the $33 \%$ brine mixture is $8 \%$ less than that for the $25 \%$ brine mixture. Therefore, at a given capacity and flow rate, the brine temperature difference across the tank will be $8 \%$ greater for the $33 \%$ mixture than it would have been for the recommended $25 \%$ mixture. As expected, the tests that were run at a higher capacity show the lowest brine temperatures. However, the brine flow rate is also an important parameter in determining the brine temperature. Figure 8 shows the variation in brine inlet temperature for tests with the approximate capacity of 19 tons and brine flows that vary from 40 to $80 \mathrm{gal} / \mathrm{min}$. Figure 9 shows the average of the brine inlet and outlet temperatures at the ice tank for these same tests. The difference between the brine inlet temperatures for the 40 - and $80-\mathrm{gal} / \mathrm{min}$ tests is $\sim 3.6^{\circ} \mathrm{F}$ (Fig. 8 ), while the difference between the average (of the brine inlet and outlet) temperatures is only about $0.9^{\circ} \mathrm{F}$ (Fig. 9). Theoretically, this average brine temperature should be strictly a function of capacity and the heat exchanger design, with the flow rate controlling the difference between the brine inlet and outlet temperatures. The data show this to be true for the Calmac tank.

The variation of the inlet and average brine temperatures with capacity is seen more clearly if tests with the same brine flow rate are compared as is shown in Figs. 10 and 11. The flow rate for all of these tests was $\sim 60 \mathrm{gal} / \mathrm{min}$. The two tests shown ending at a capacity $<140$ ton-h were at a brine concentration of $25 \mathrm{wt} \%$. The others were at a concentration of $33 \mathrm{wt} \%$. As shown on Fig. 10, the brine inlet temperature ranged from a low of $18^{\circ} \mathrm{F}$ at 30 tons to a high of $27^{\circ} \mathrm{F}$ at 9 tons. The average brine temperatures show less variation, ranging from $25^{\circ} \mathrm{F}$ at 30 tons to $29^{\circ} \mathrm{F}$ at 9 tons.

To aid customers in selecting the proper chiller, Calmac provides the average and minimum brine temperatures to the ice tank during charge cycles of varying capacities and flow rates. These are shown in Figs. 12 and 13, along with the comparable values measured during the tests. The average brine inlet temperatures were all within the range reported by Calmac, within the measurement accuracy of $\pm 0.5^{\circ} \mathrm{F}$. The minimum brine inlet temperatures were also within the reported values, except for a few tests run at capacitics of 26 to 31 tons. The brine concentration for these tests was $33 \mathrm{wt} \%$, which would exaggerate the difference between the inlet and outlet temperatures by $\sim 8 \%$ as was discussed previously. This, coupled with the measurement accuracy, would easily place the test values within the range reported by Calmac. 


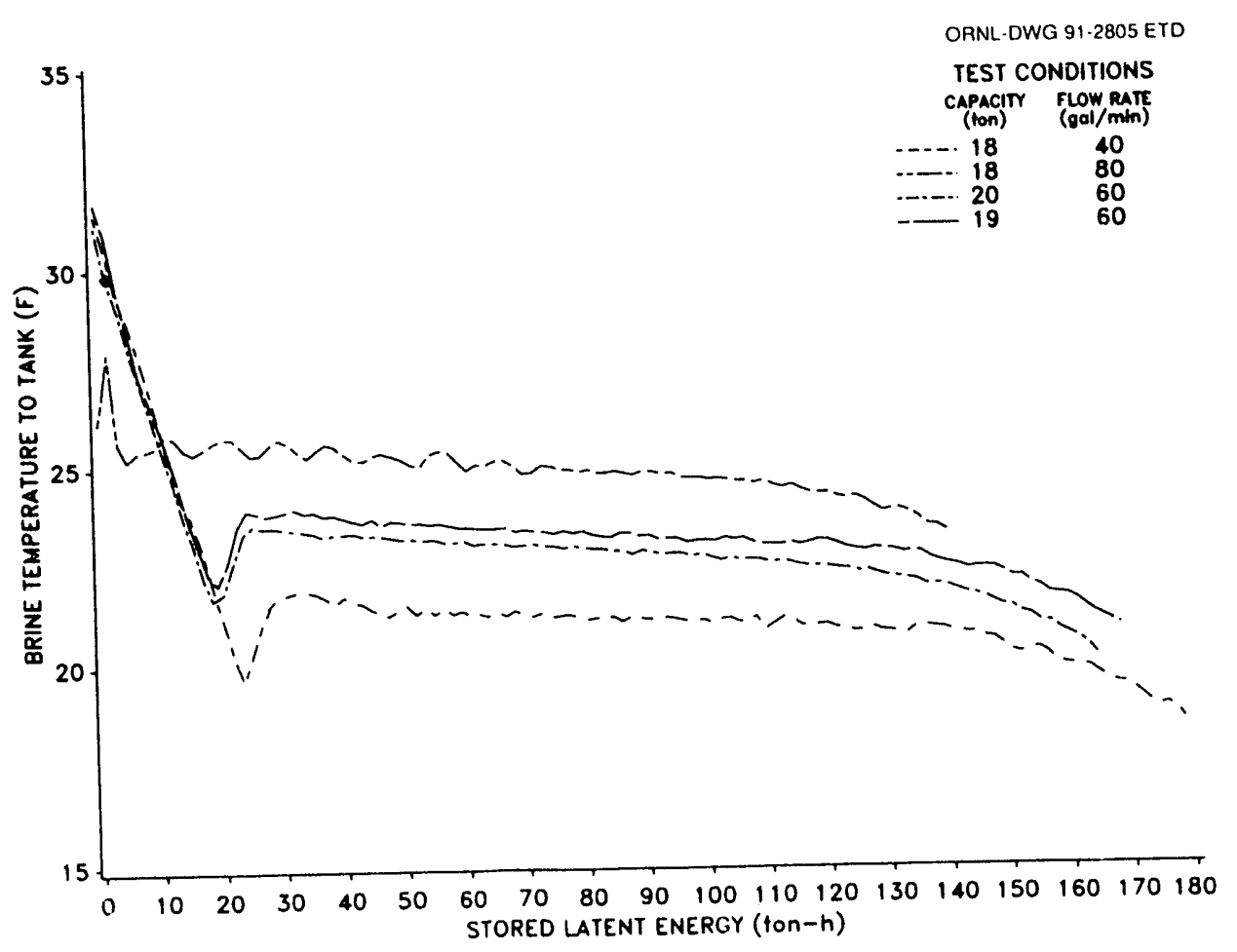

Fig. 8. Tank inlet temperature vs calculated stored energy for Calmac charge tests with average capacity from 18 to 20 tons and brine flow rates of 40,60 , and $80 \mathrm{gal} / \mathrm{min}$. All temperature measurements are $\pm 0.5^{\circ} \mathrm{F}$.

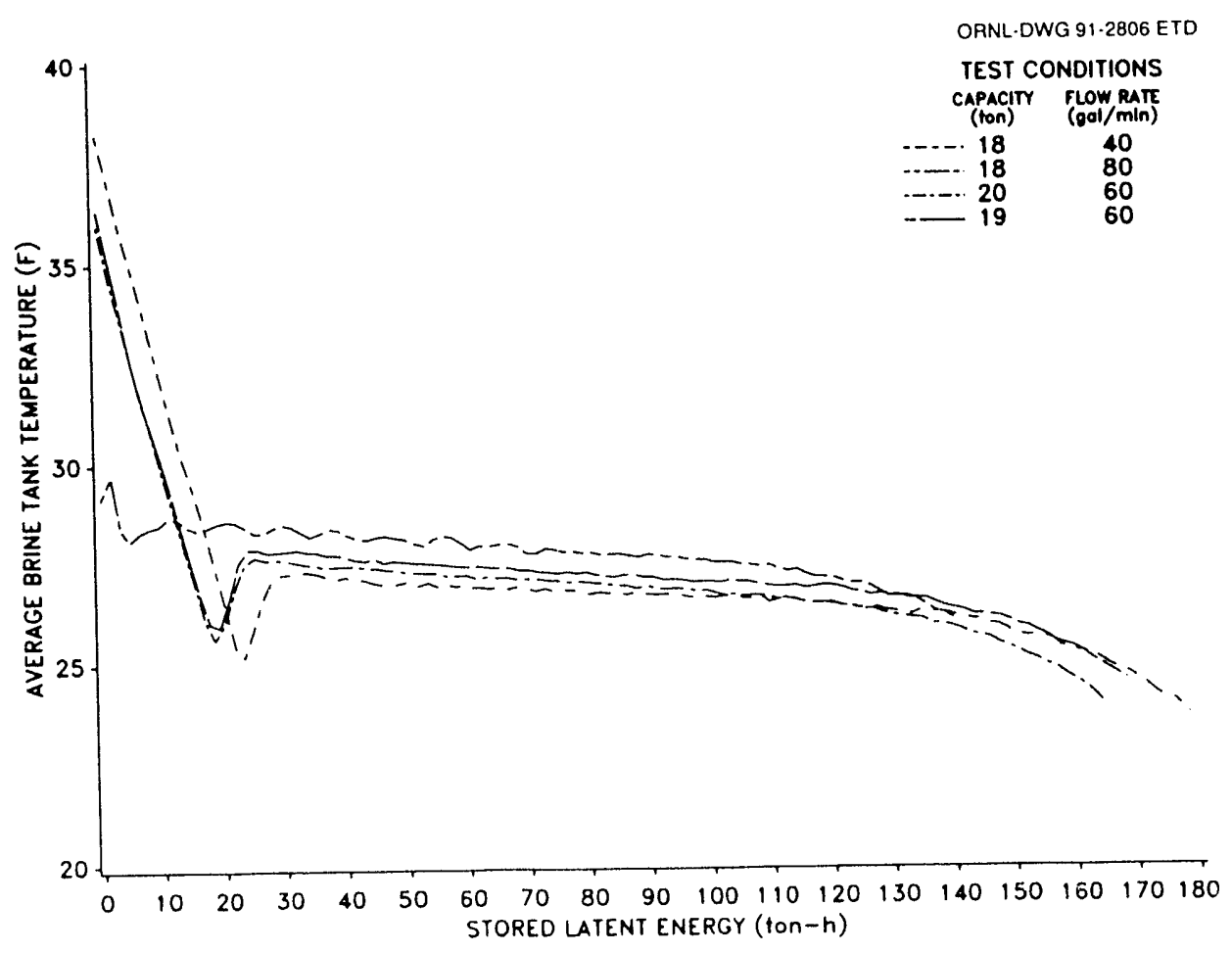

Fig. 9. Average of tank inlet and outlet temperatures vs calculated stored energy for Calmac charge tests with average capacity from 18 to 20 tons and brine flow rates of 40,60 , and $80 \mathrm{gal} / \mathrm{min}$. All temperature measurements are $\pm 0.5^{\circ} \mathrm{F}$. 


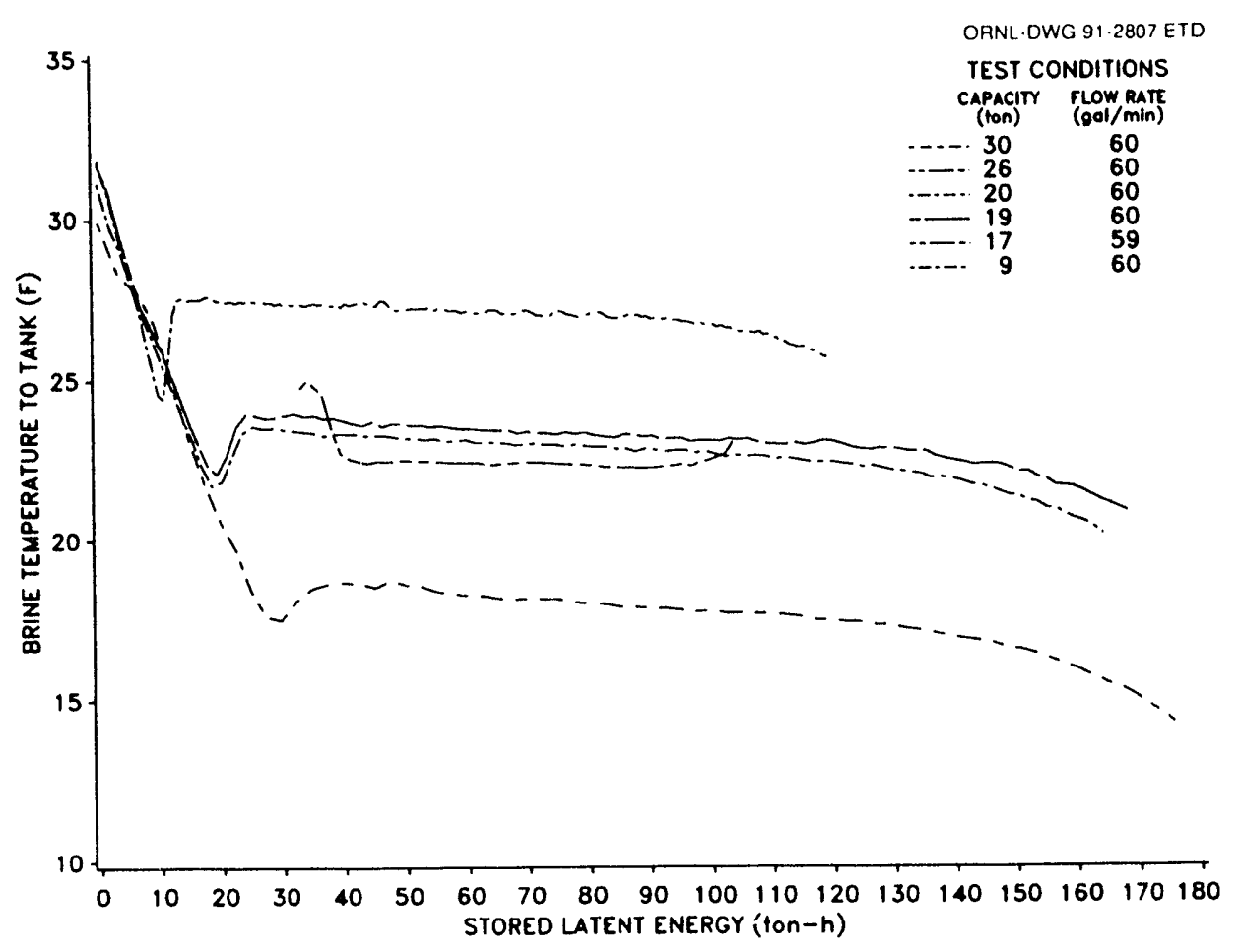

Fig. 10. Tank inlet temperature vs calculated stored energy for Calmac charge tests with brine flow rate of $60 \mathrm{gal} / \mathrm{min}$ with various average capacities and two different brine concentrations. All temperature measurements are $\pm 0.5^{\circ} \mathrm{F}$.

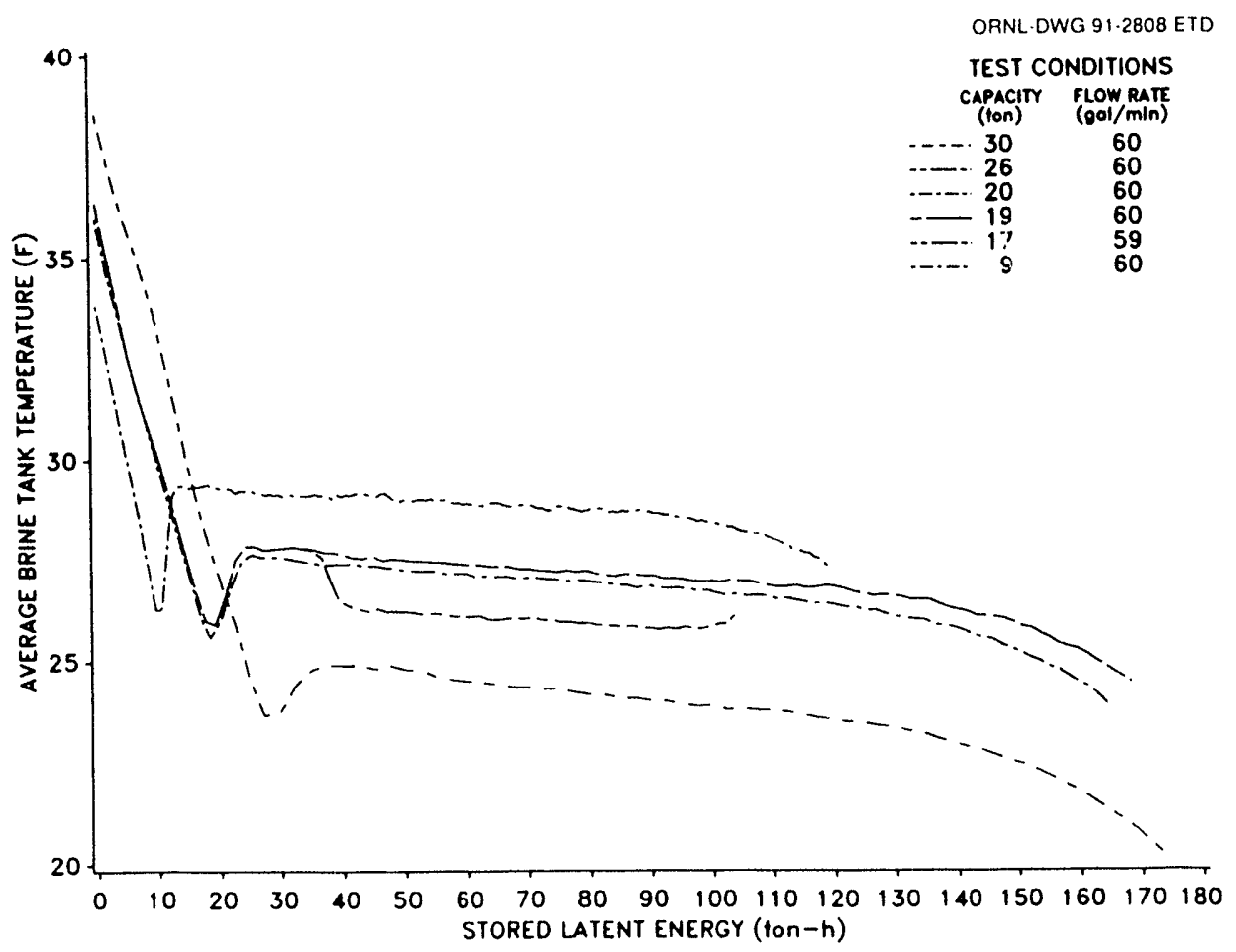

Fig. 11. Average of tank inlet and outlet temperatures vs calculated stored energy for Calmac charge tests with brine flow rate of $60 \mathrm{gal} / \mathrm{min}$ with various average capacities and two different brine concentrations. All temperature measurements are $\pm 0.5^{\circ} \mathrm{F}$. 


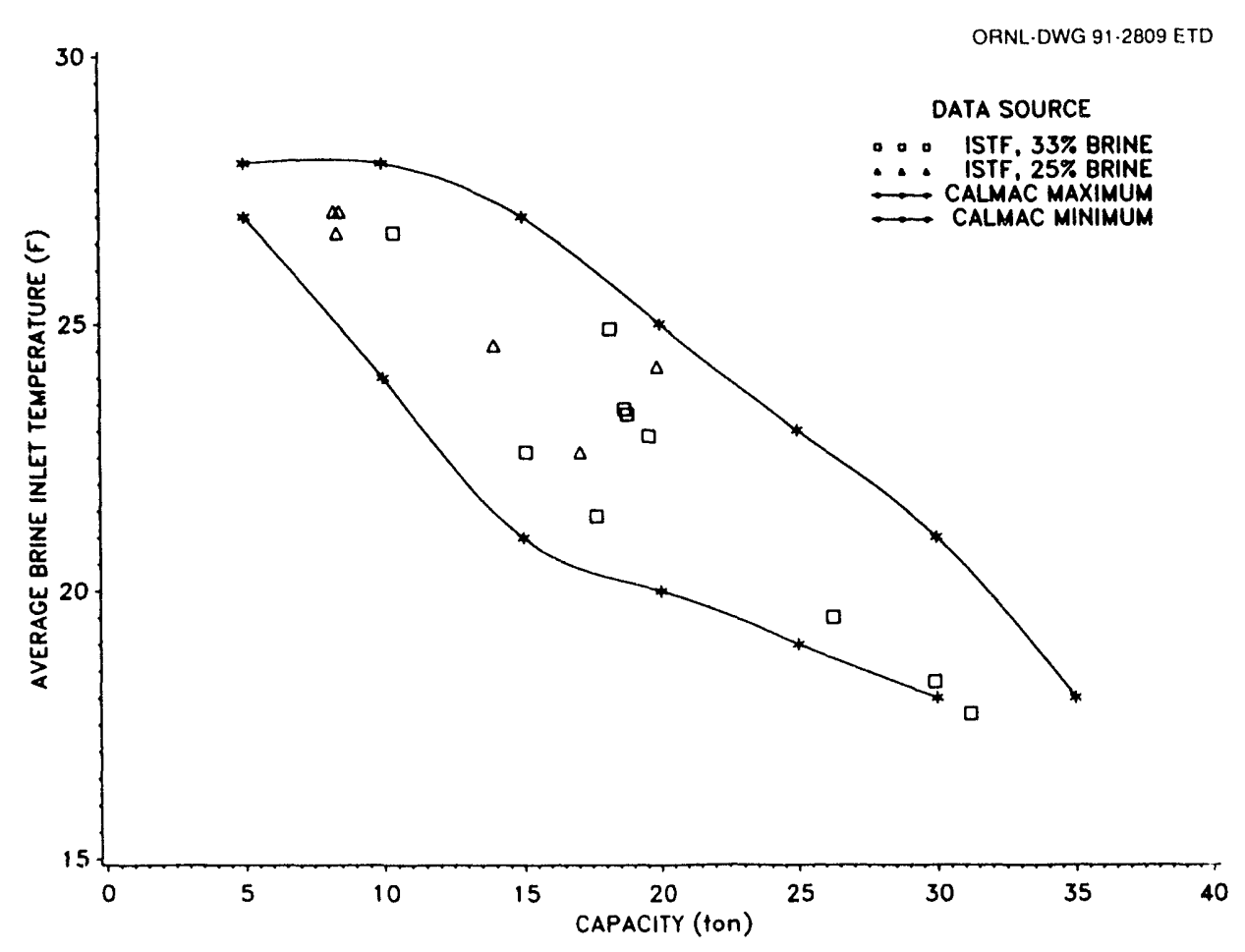

Fig. 12. Comparison of measured average brine inlet temperatures to reported values. All measured temperatures are $\pm 0.5^{\circ} \mathrm{F}$.

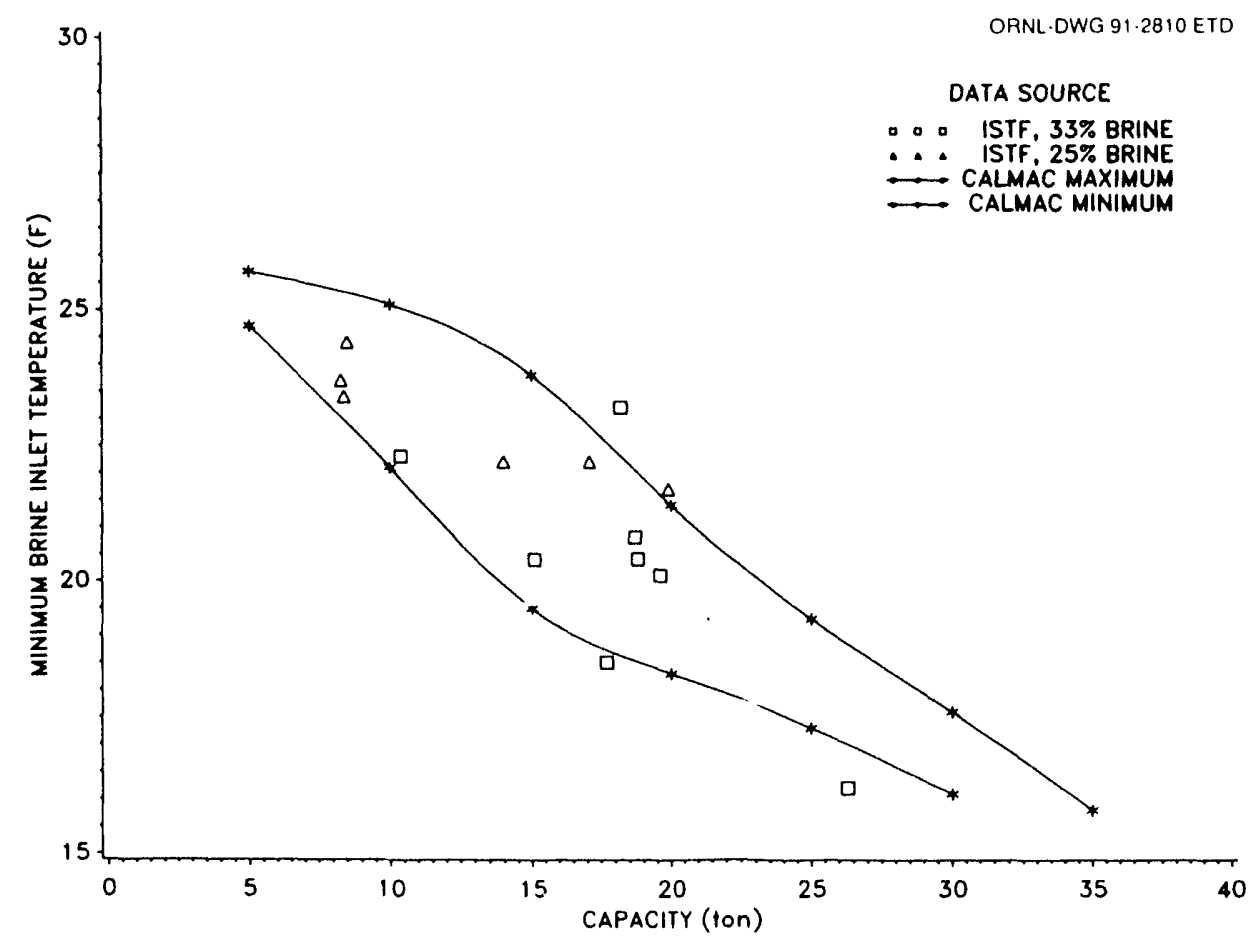

Fig. 13. Comparison of measured minimum brine inlet temperatures to reported values. All temperature measurements are $\pm 0.5^{\circ} \mathrm{F}$. 
Traditional packaged chiller data provide adequate guidance when selecting equipment for constant temperature systems, such as air conditioners, but are less useful for ice storage systems. Figure 14 shows data that are typically available for a packaged chiller/condensing unit. The catalog data usually give the capacity as a function of condensing temperature and brine outlet temperature for a given range of brine temperature changes. Correction factors for brine concentration are also given or can be obtained from the manufacturer. In Fig. 14, the catalog data for water chilling have been extiapolated to temperatures commonly encountered when making ice (such extrapolations must be checked with the chiller manufacturer). The test data were examined to find a method of predicting overall system performance, given variable load temperatures and this type of chiller data based on a constant load temperature.

Calmac provides the average and minimum brine inlet temperatures, as was shown in Figs. 12 and 13. To provide a greater level of detail, the ISTF data were correlated with tank state-of-charge (relative to the rated full latent charge). The latent tank charge was chosen so that the results could be used for tanks of similar design but with different storage capacities. Figure 15 shows the system capacity vs brine inlet temperature for the ice tank at $10,25,50,75$, and $100 \%$ charge for a brine flow rate of $6 \mathrm{gal} / \mathrm{min}$. The tank state of charge is based on the cumulative capacity measured by the brine flow and temperature change in the ice tank. The lines shown are linear regressions based on the data points. As expected, the linear regressions show very strong adjusted squared correlation coefficients, 0.88 for $25 \%, 0.89$ for $50 \%, 0.82$ for $75 \%$, and 0.97 for $100 \%$ frozen. This figure can therefore be used to assess the range of operating conditions that the chiller must experience during a charge cycle. A system designer, knowing the condensing temperature, brine concentration, and brine flow rate, can choose the appropriate chiller data and overlay this curve on Fig. 15. The result is shown in Fig. 16. The system performance will be found at the intersections of the chiller data and the ice storage tank data. These values can be used to more precisely estimate the time necessary to charge the tank, especially if the tank charge begins from a partially frozen state.

Equation (17) was developed from the test data to express the capacity as a function of the brine inlet temperature, the tank state of charge, and the brine flow rate. This equation explained $\sim 69 \%$ of the data variation, based on the adjusted squared correlation coefficient, and all the parameter estimates were significant at $>97 \%$, based on the Student's T-test. This equation can be interpreted as indicating that the capacity increases $\sim 2.2$ tons 


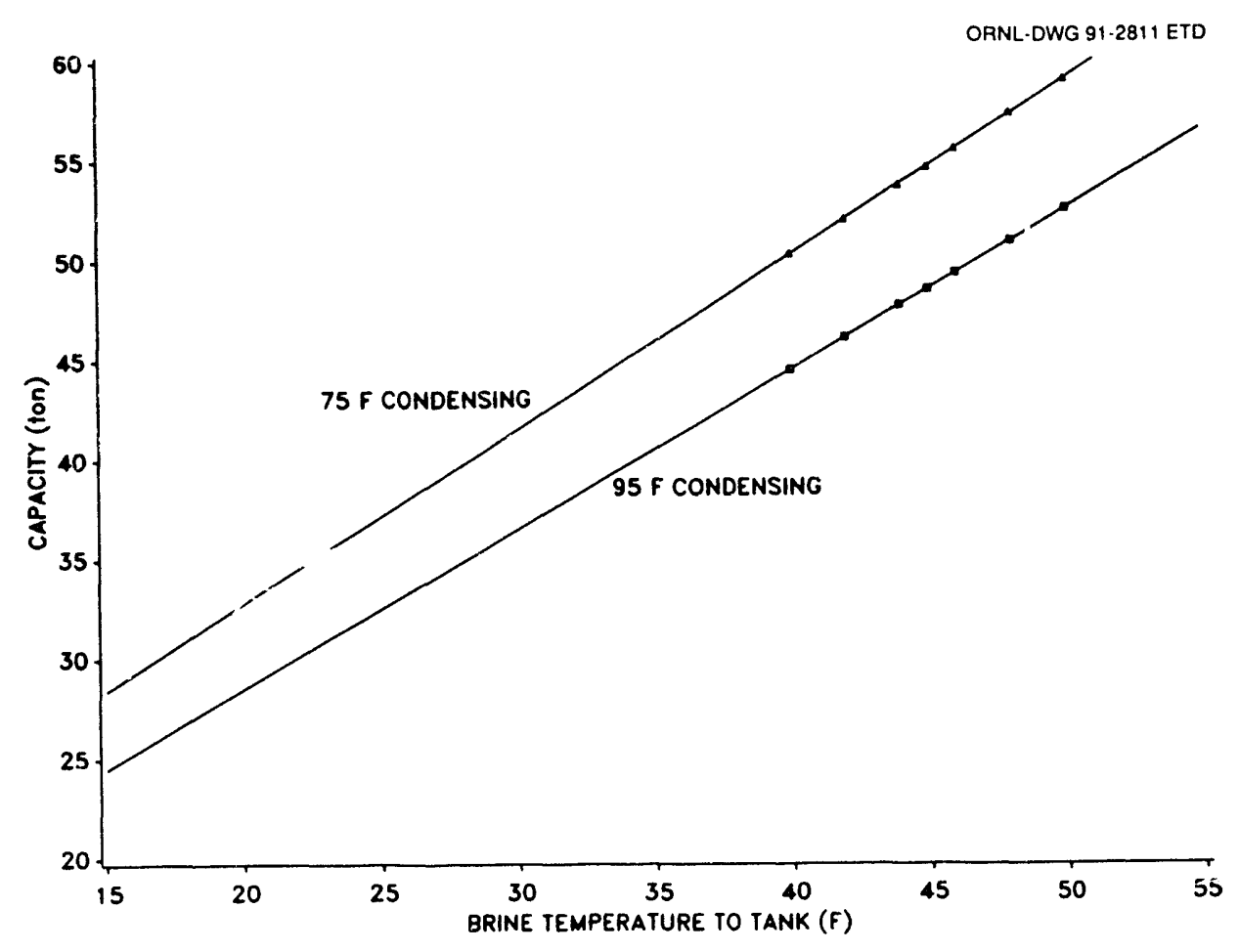

Fig. 14. Example of packaged shiller capacity data for two condensing temperatures.

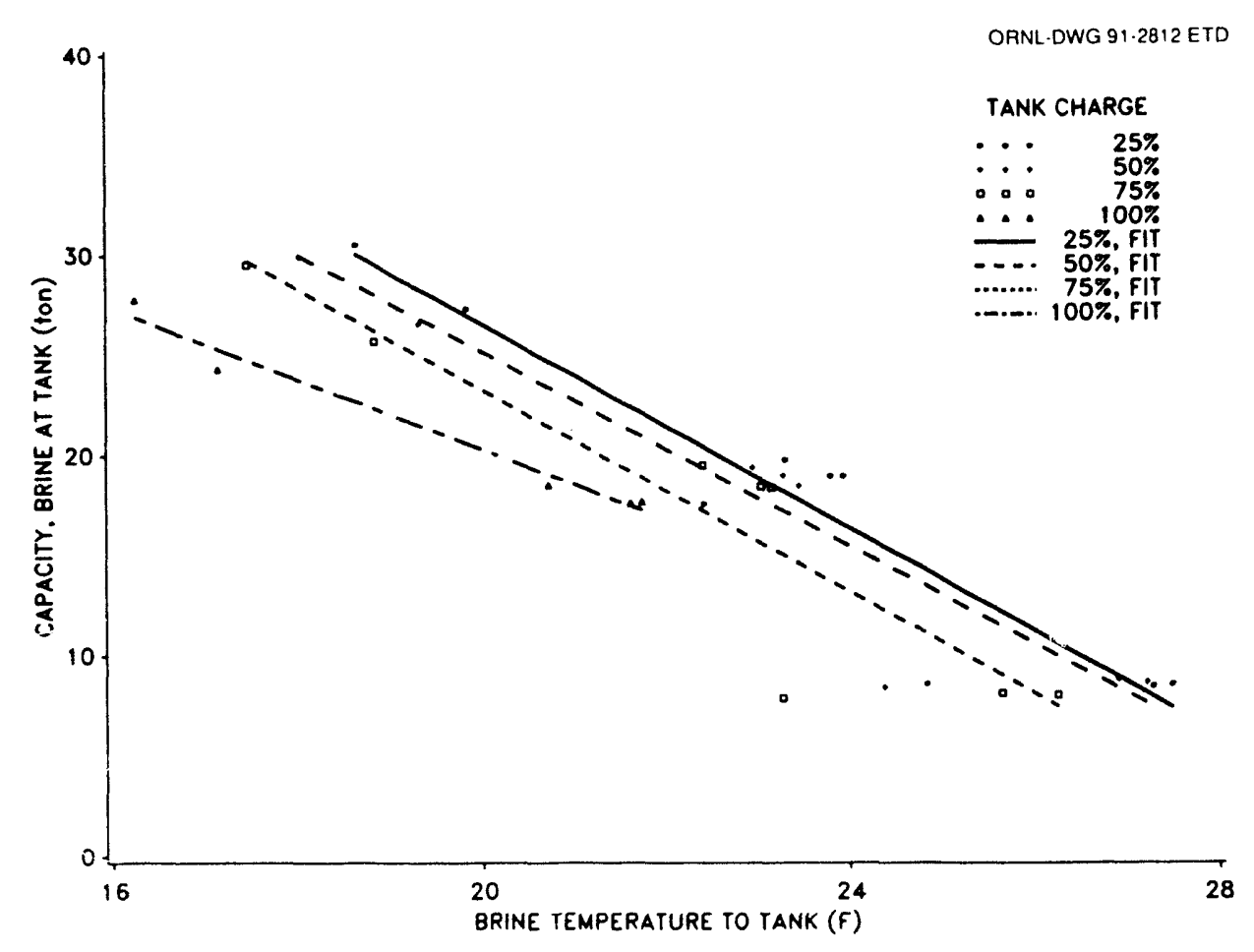

Fig. 15. Capacity vs storage tank brine inlet temperature for tank charges from 25 to $100 \%$ frozen for Calmac storage tank at brine flow rate of $60 \mathrm{gal} / \mathrm{min}$. All temperature measurements are $\pm 0.5^{\circ} \mathrm{F}$. 


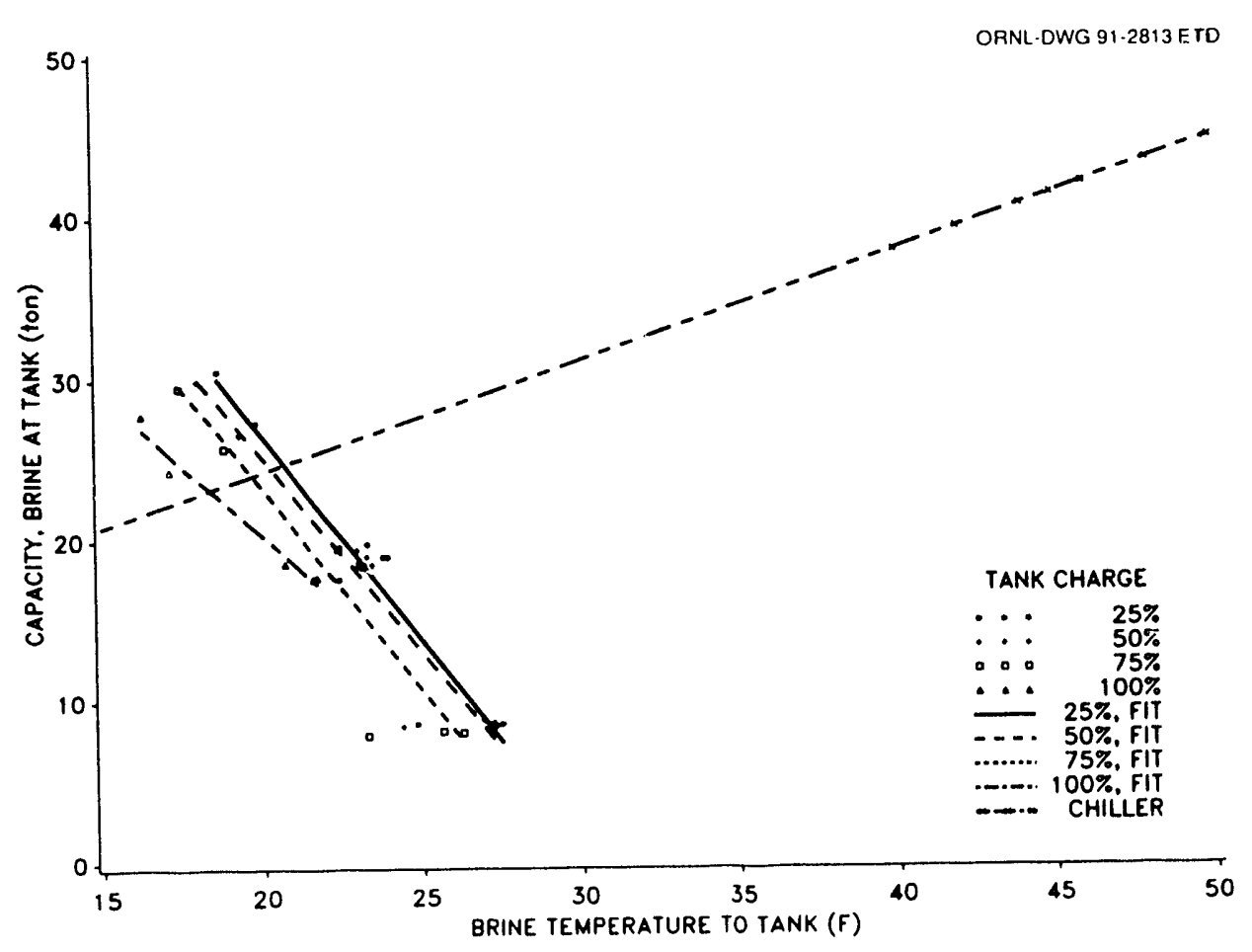

Fig. 16. Application ot package chiller data to ice storage data when designing system.

for each drop of $1^{\circ} \mathrm{F}$ in the brine iniet temperature, decreases about 0.078 ton for each percent increase in the tank charge (i.e., drops $\sim 0.78$ ton as the tank goes from 60 to $70 \%$ charged), and increases $\sim 0.1$ ton for each increase in the brine flow rate of $1 \mathrm{gal} / \mathrm{min}$. Two of these parameters offset each other, because the brine temperature drops as the tank cl:arge increases. Recalling that the capacity is approximately constant as the tank charge increases from 20 to $70 \%$ (see Fig. 5), this equation predicts that the brine inlet temperaiure wsuld drop $\sim 1.8^{\circ} \mathrm{F}$. This agrees well with the trends shown on Fig. 10.

$$
\mathrm{Re}_{\mathrm{b}}=64.9-2.2 \times \mathrm{TE} 16-0.078 \times \mathrm{SC}+0.097 \times \mathrm{FE} 4
$$

where

$$
\begin{aligned}
\mathrm{Re}_{\mathrm{b}} & =\text { refrigeration effect (ton) } \\
\mathrm{TE} 16 & =\text { tank brine inlet temperature }\left({ }^{\circ} \mathrm{F}\right) \\
\mathrm{SC} & =\text { state of charge }(\%) \\
\mathrm{FE} 4 & =\text { brine flow rate }(\mathrm{gal} / \mathrm{min})
\end{aligned}
$$

The cumulative capacity is shown in Fig. 17. This plot shows that there was no difficulty in fully charging the storage system under a wide range of charging rates. 


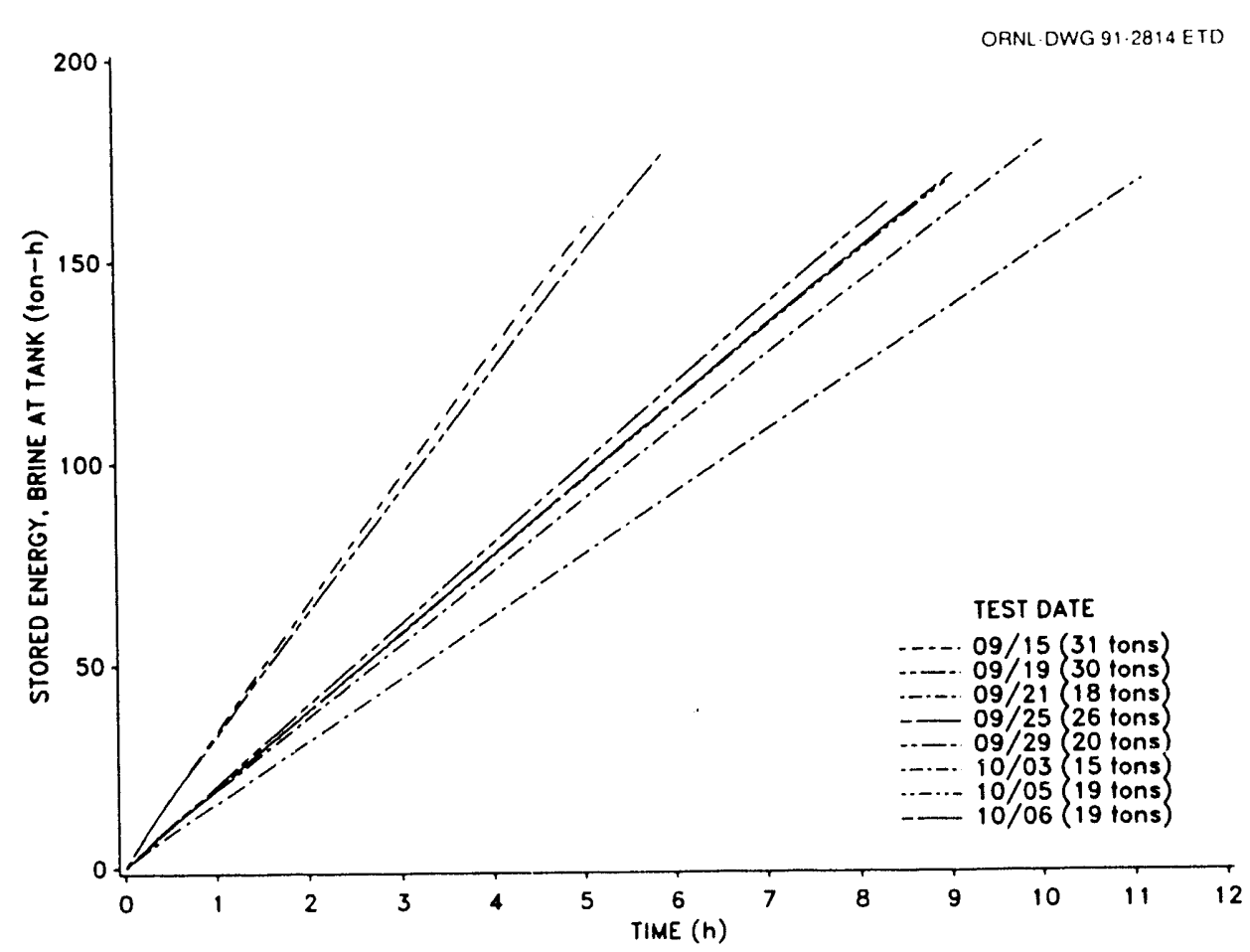

Fig. 17. Summary of cumulative energy storage in ice tank for Calmac charge tests.

The only auxiliary power requirement for the system is the brine pump. The pump power ranged from $\sim 1 \mathrm{~kW}$ at $40 \mathrm{gal} / \mathrm{min}$ to $\sim 4 \mathrm{~kW}$ at $80 \mathrm{gal} / \mathrm{min}$. If a 30 -ton compressor was running at the higher flow rate with a compressor power consumption of $1.2 \mathrm{~kW} / \mathrm{ton}$, this additional power use and heat addition (assuming that the pump power is converted to heat in the brine, thereby reducing the available cooling capacity) would increase overall power consumption to $\sim 1.4 \mathrm{~kW} /$ ton, an increase of $\sim 15 \%$. At the lower flow rate for the same example case, the additional power use and heat addition would increase overall power consumption to $\sim 1.25 \mathrm{~kW} / \mathrm{ton}$, an increase of $\sim 4 \%$. If the system capacity was defined to be 30 tons to the load (i.e., pumping heat addition is not considered), then the higher flow rate case would have an overall power consumption of $1.3 \mathrm{~kW} /$ ton (an $11 \%$ increase) and the lower flow rate example would have an overall power consumption of $1.23 \mathrm{~kW} / \mathrm{ton}$ (a $3 \%$ increase).

\subsection{DISCHARGE PERFORMANCE}

The discharge tests were summarized in Table 6. The results presented here are based on test data prior to the tank outlet temperature reaching $48^{\circ} \mathrm{F}$. Later in this section, 
the effect of maximum acceptable outlet temperature on the total available capacity is discussed.

As mentioned in Sect. 4.3, the discharge capacity was measured in three different ways. Figure 18 shows the relative consistency of these different values in calculating the cool storage harvested from the ice tank. The heater energy electrical measurements are always low because of thermal losses in the heater power electrical controller. These measurements were not used in capacity calculations. The water-side measurement at the heater should be slightly less than the water-side measurement at the tank because of heat gains by the circulation pumps. Temperature measurement errors of $\pm 0.5^{\circ} \mathrm{F}$ can occur at any of the four monitoring points used to calculate the change in water temperature across the tank and heater.

The water temperature leaving the ice tank varied according to the discharge rate and the water temperature entering the tank. Figures 19 and 20 show the discharge temperature profiles vs the tank state of charge. The state of charge is calculated as was described in Sect. 4, where the cumulative capacity, based on brine flow and temperature change in the ice tank, is subtracted from the initial inventory of ice. During normal operations, the tank would be frozen to a height of 6 in. above the fully melted height at the start of a discharge. At 23.2 ton-h/in., this represents $\sim 140$ ton-h of latent storage. The measured height at the start of the tests reported here ranged from 5.5 to 6.25 in. If the brine held in piping outside the tank reached room temperature before the beginning of the melt test, it would require $\sim 3$ ton-h to cool the brine down to $32^{\circ} \mathrm{F}$. Some of the slower melt tests took place over a 2-d period, during which this brine inventory would need to be cooled down twice. These two effects, variation in initial ice inventory (from 128 to 151 ton-h) and brine heat gains (from 0 to 6 ton-h) during shutdown periods, cause the different starting points shown in Figs. 19-21. The values extend to a state of charge less than zero because sensible energy is also being harvested from the storage tank. The shape of the temperature curve is noticeably different for those tests run at capacities $>35$ tons, including 0925, 1002, 0920, and 0926 . These high-capacity tests experience their steepest temperature changes in the beginning of the test; whereas the data for tests at capacities lower than $\sim 20$ tons show a trend of a more moderate rise during the first two-thirds of the tests, followed by a rapid temperature incr-ase near the end of the test. Test 0927 , between these two extremes at 28 tons, showed a nearly linear temperature rise vs the tank's latent state of charge. 


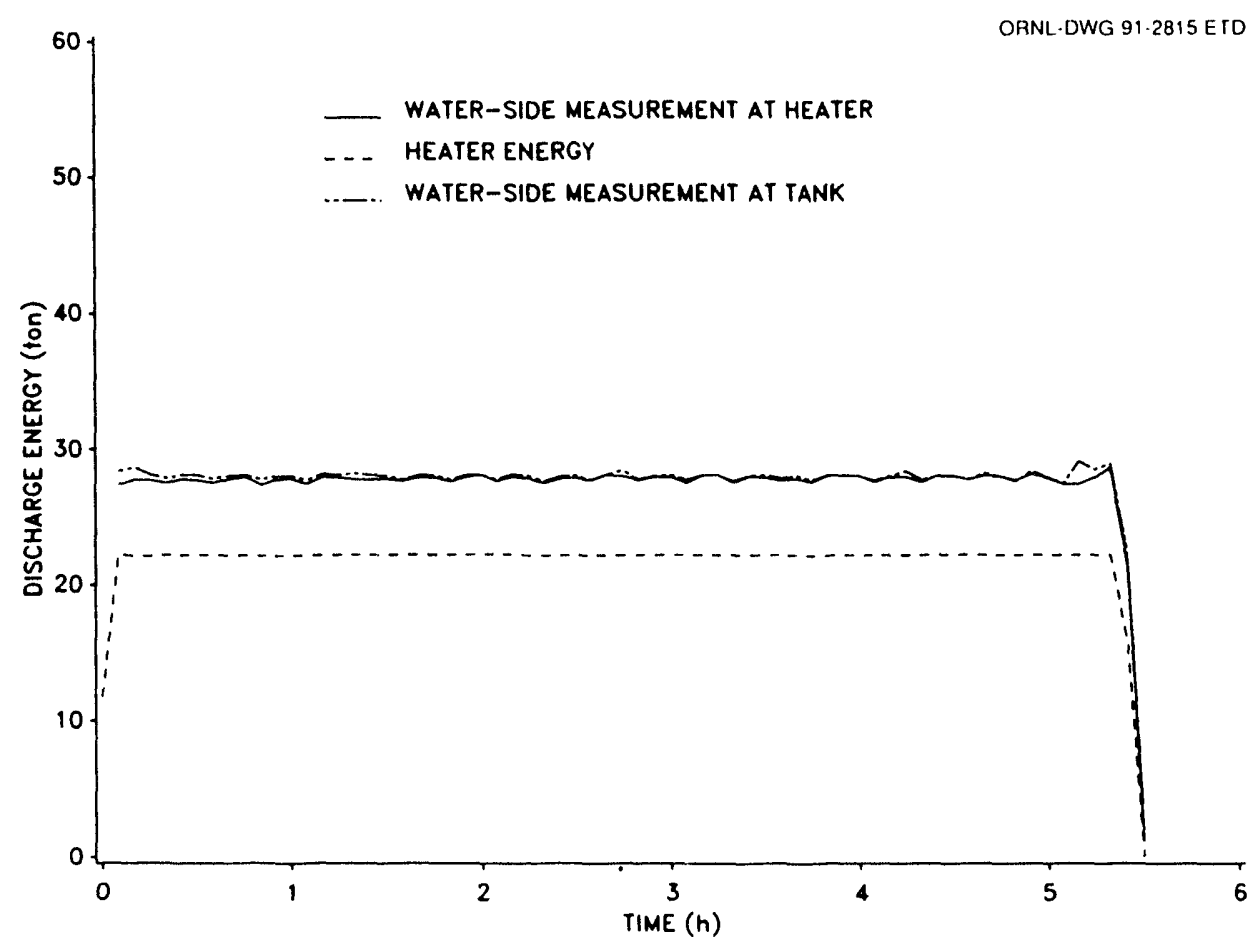

Fig. 18. Comparison of discharge energy as measured at three different locations from test run on Jan. 29, 1990.

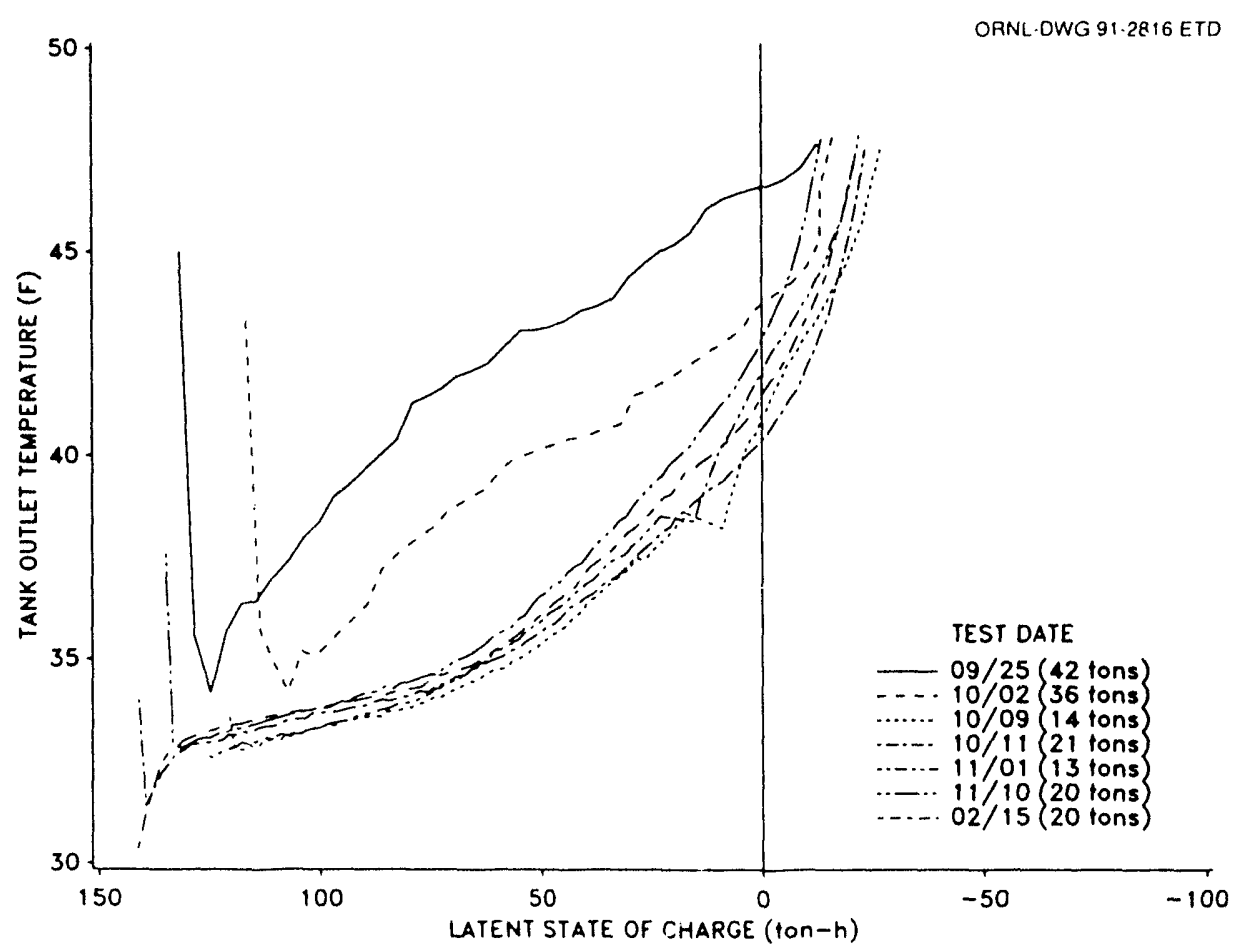

Fig. 19. Calmac discharge test summary for water with tank inlet temperature of $60^{\circ} \mathrm{F}$ : tank water outlet temperature vs tank latent state of charge. All temperature measurements are $\pm 0.5^{\circ} \mathrm{F}$. 


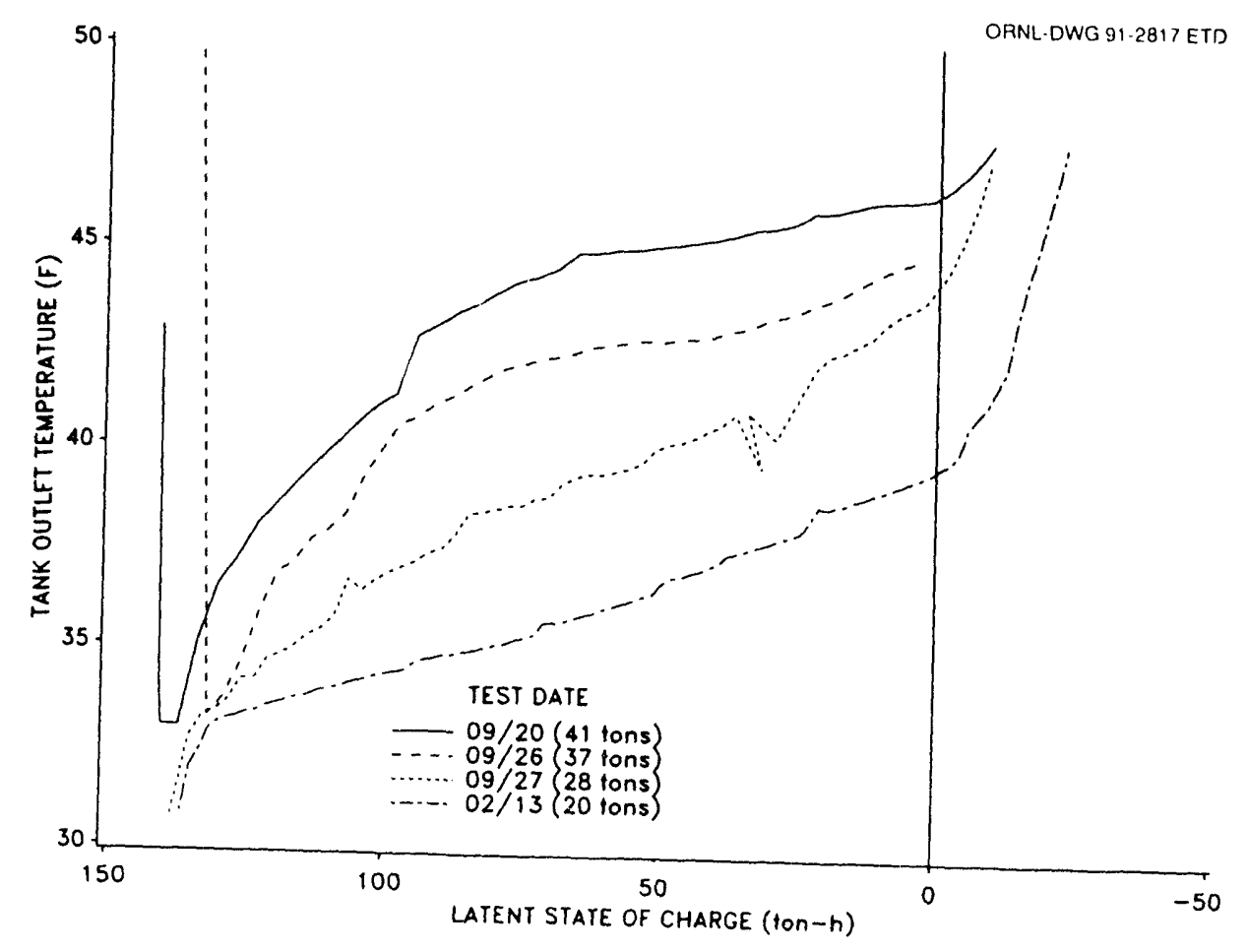
Fig. 20. Calmac discharge test summary for water with tank inlet temperature
of $50^{\circ} \mathrm{F}$ : tank water outlet temperature vs tank latent state of charge. All temperature
measurements are $\pm 0.5^{\circ} \mathrm{F}$. measurements are $\pm 0.5^{\circ} \mathrm{F}$.

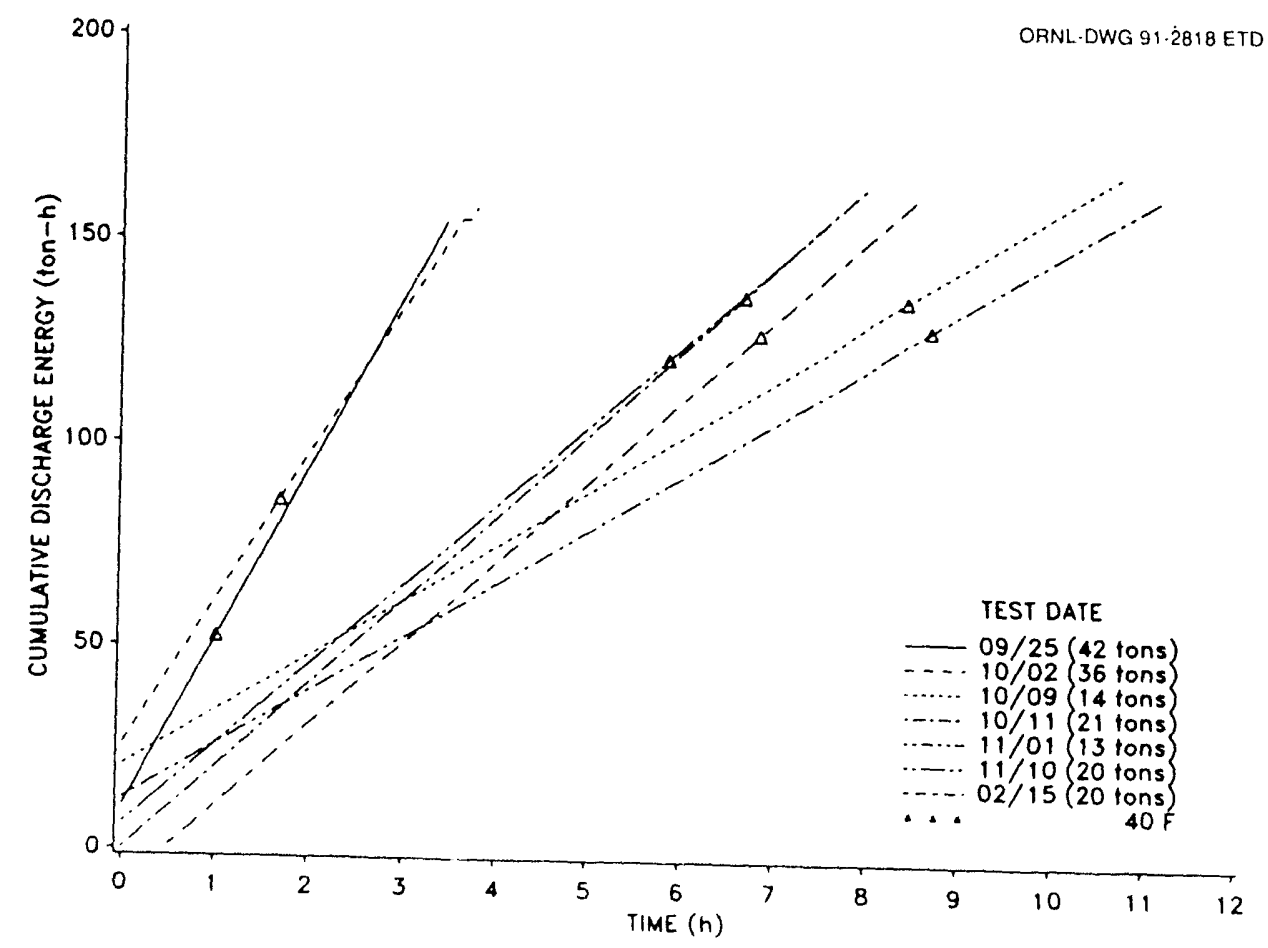
Fig. 21. Calmac discharge test summary for tests with tank inlet temperature of $60^{\circ} \mathrm{F}$.
Tests end when tank outlet temperature reaches $48^{\circ} \mathrm{F}$. 
As the Calmac literature predicts, the energy available during a discharge is strongly dependent on the allowable temperature of the brine leaving the ice storage tank. Figure 21 shows the cumulative energy provided by the storage tank during several discharge tests. As for Figs. 19 and 20, the starting point for each curve has been adjusted according to the initial charge of ice within the tank. The triangles shown on each line represent the point at which the tank outlet temperature exceeded $40^{\circ} \mathrm{F}$, and the end point of each line represents the point at which the brine outlet temperature reached $48^{\circ} \mathrm{F}$. Figure 21 shows that more energy is available for a given tank outlet temperature if the tank is discharged at a slower rate. Data points corresponding to the time at which the tank outlet exceeded $36,40,44$, and $48^{\circ} \mathrm{F}$ were selected and are shown in Figs. 22 and 23, for tank inlet temperatures of 60 and $50^{\circ} \mathrm{F}$, respectively. Also shown on these figures are curves taken from the Calmac literature and curves generated based an a regression analysis of the test data. Many combinations of explanatory variables were tested to find the best fit to the data, resulting in Egs. (18) and (19) for tank inlet temperatures of 60 and $50^{\circ} \mathrm{F}$, respectively. These equations explain $\sim 95 \%$ of the variation in the cumulative discharge energy, as measured by the adjusted squared correlation coefficient. All the parameter estimates are significant at the 0.95 level as measured by a Student's T-test. These parameter estimates and their standard errors are listed in Table 7.

$$
\begin{aligned}
& \Sigma \text { cap }_{\mathrm{t}}=-125.2-15.7 / \tau+4.7 \times \tau \times \mathrm{e}^{[(12-r) / 2]}+5.1 \times \mathrm{T}, \\
& \Sigma \mathrm{cap}_{\mathrm{t}}=-146.0+43.6 \times \tau-38.7 \times \tau \times \mathrm{e}^{\mathrm{d}(\mathrm{r}-12) / 12]}+4.0 \times \mathrm{T},
\end{aligned}
$$

where

$\Sigma$ cap $_{\mathrm{t}}=$ cumulative discharge capacity measured at the ice tank (ton-h),

$\tau=$ time from start of discharge test (h),

$\mathrm{T}=$ brine temperature leaving the storage tank $\left({ }^{\circ} \mathrm{F}\right)$.

The issue of the effect of the brine concentration was also addressed during the analysis of the discharge data. Figures 24 and 25 show the difference in tank outlet temperature and brine flow rates for tests 1009 and 1101, both with capacities of $\sim 14$ tons, and tests 1011 and 1110 , both with capacities of $\sim 20$ tons. The heater outlet temperature for these tests was controlled at $60^{\circ} \mathrm{F}$. Based on these comparisons, the increased 


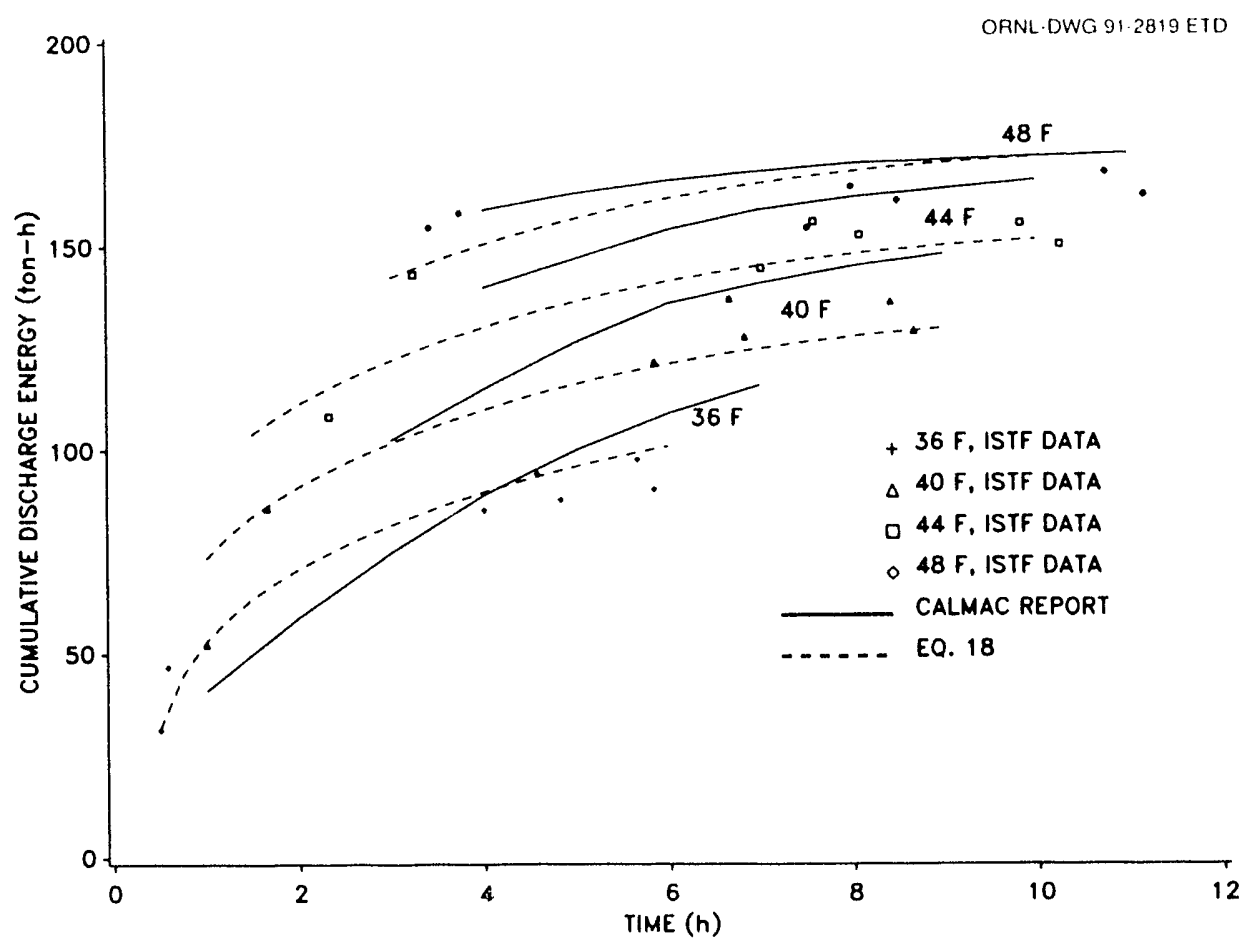

Fig. 22. Calmac discharge test summary for tank filled with water with tank inlet of $60^{\circ} \mathrm{F}$ : cumulative discharge energy available for maximum tank outlet temperatures of 36 , 40,44 , and $48^{\circ} \mathrm{F}$ for different discharge rates. All temperature measurements are $\pm 0.5^{\circ} \mathrm{F}$.

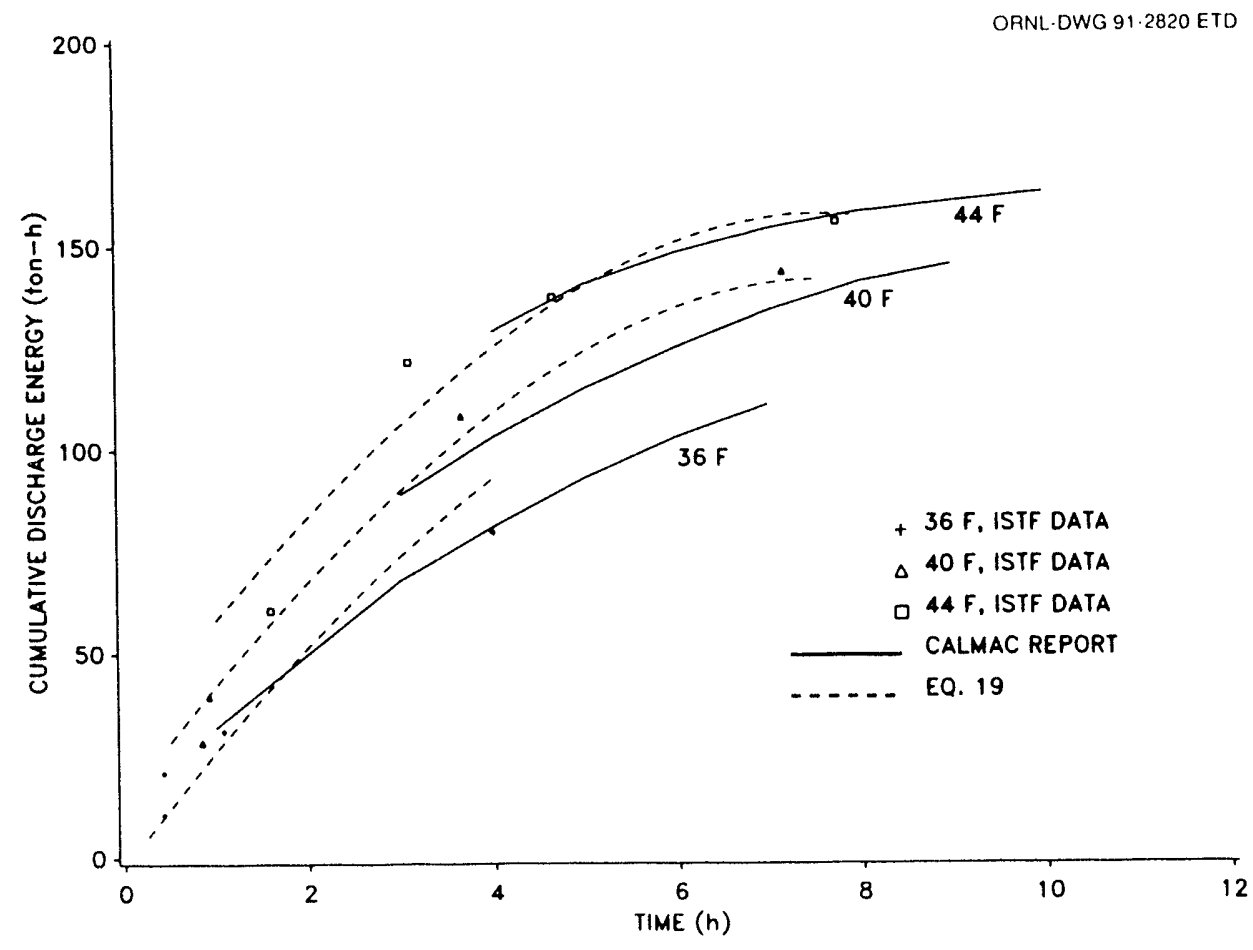

Fig. 23. Calmac discharge test summary for tank filled with water with tank inlet of $50^{\circ} \mathrm{F}$ : cumulative discharge energy available for maximum tank outlet temperatures of 36 , 40 , and $44^{\circ} \mathrm{F}$ for different discharge rates. All temperature measurements are $\pm 0.5^{\circ} \mathrm{F}$. 
Table 7. Parameter estimates for Eqs. (18) and (19)

\begin{tabular}{lcc}
\hline \multicolumn{1}{c}{ Parameter } & Estimate & Standard error \\
\hline & Eq. (18) & \\
Intercept & -125. & 20.9 \\
$1 / \tau$ & -15.7 & 7.64 \\
$\tau \times \mathrm{e}^{[(12-\mathrm{r}) / 12]}$ & 4.69 & 1.11 \\
$\mathrm{~T}$ & 5.06 & 0.427 \\
& Eq. (19) & \\
Intercept & -146. & 38.2 \\
$\tau$ & 43.6 & 8.03 \\
$\tau \times \mathrm{e}^{[((-12) / 12]}$ & -38.7 & 11.2 \\
$\mathrm{~T}$ & 4.00 & 1.01 \\
\hline
\end{tabular}

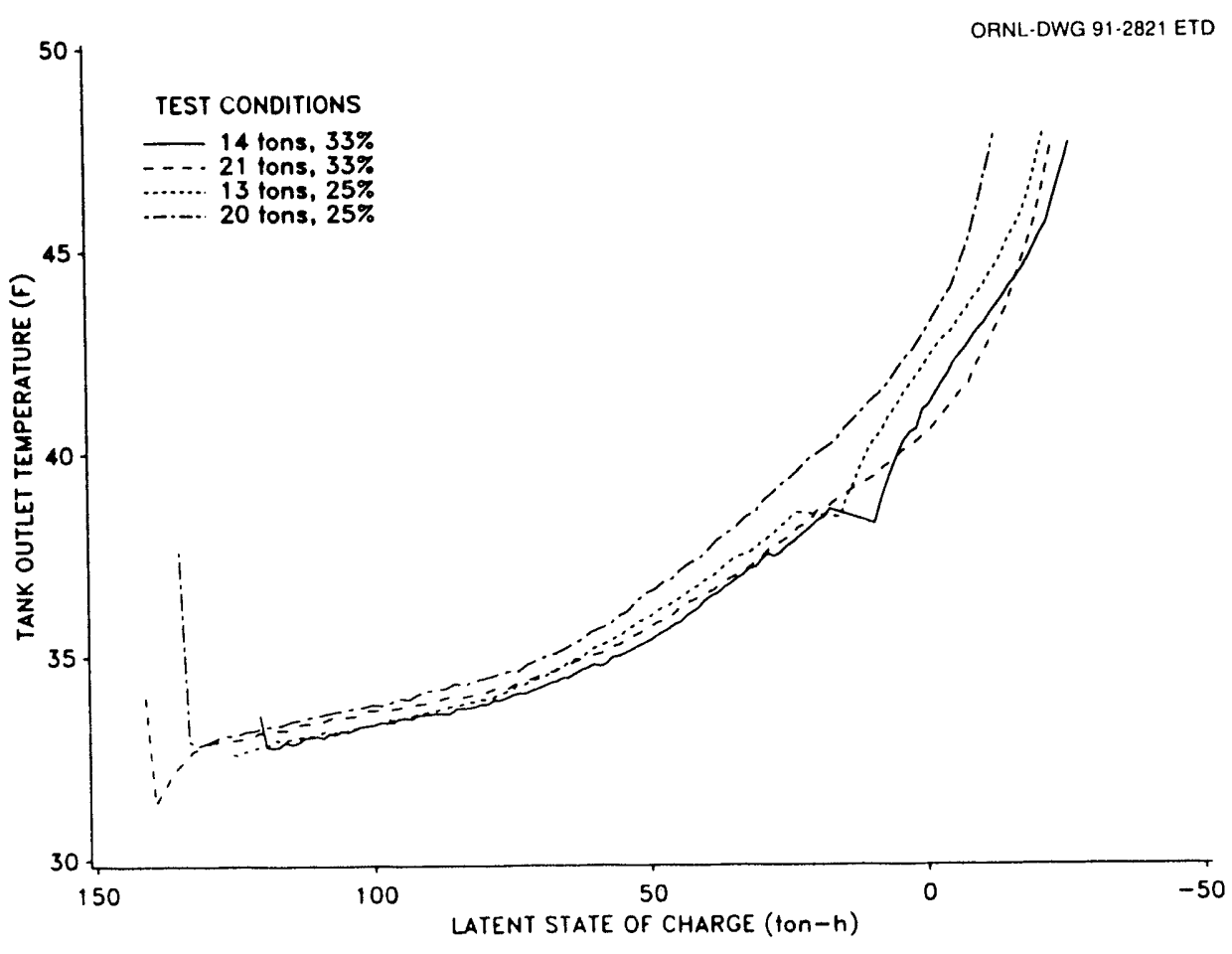

Fig. 24. Selected Calmac discharge tests to compare effects of brine concentration on brine tank outlet temperature. All temperatures are $\pm 0.5^{\circ} \mathrm{F}$. 


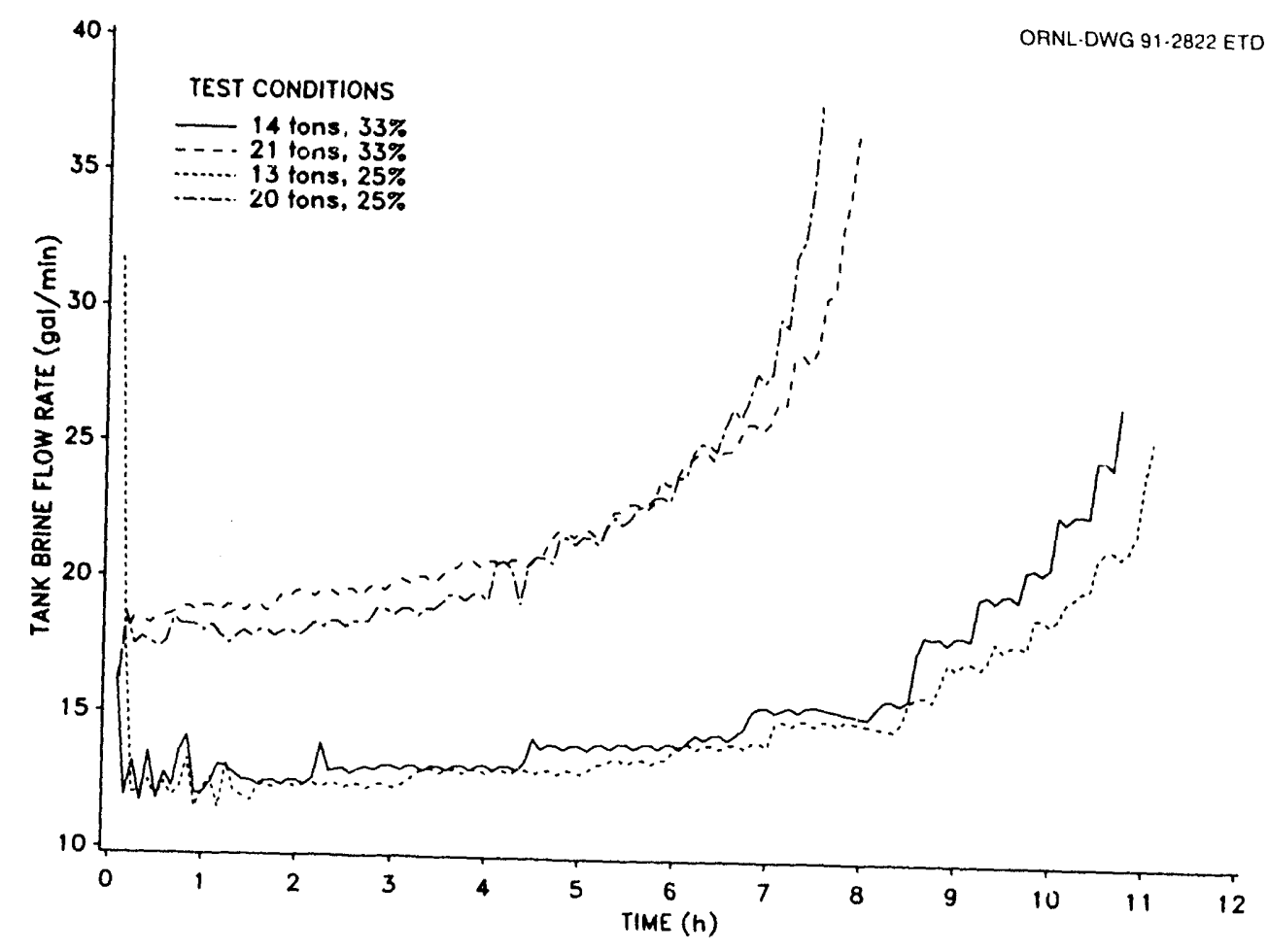

Fig. 25. Selected Calmac discharge tests to compare effects of brine concentration
flow rate. on brine flow rate.

concentration of brine used for many of the tests is not likely to affect the results reported here.

Power requirements during discharge include brine pumping power. The pumping power varies with the prime flow rate and ranged from 0.24 to $4.6 \mathrm{~kW}$. This accounted for an approximate heat input to the brine of between 0.7 to 5.1 ton-h over the course of the discharge cycle, assuming that all the pump power is converted to heat in the brine.

\subsection{STANDBY HEAT GAINS}

Standby heat gains were measured in a test that spanned a period of almost 2 months. The change in tank depth, with the measured ice density of $57.2 \mathrm{lb} / \mathrm{ft}^{2}$ and an ice heat of fusion of $144 \mathrm{Btu} / \mathrm{b}$, gave the latent heat gain for the tank containing ice. This calculation assumes that all the water in the tank remains at $32^{\circ} \mathrm{F}$, which is reasonable considering the large and well-distributed ice inventory throughout the test. Over a period of $1420 \mathrm{~h}$, the tank lost a total of 88 ton-h of ice, corresponding to a standby loss rate of 0.06 ton. Based on the rated maximum storage capacity of 190 ton-h, this loss rate can be expressed as 
0.0003 ton/ton-h, or alternatively, it would take $3170 \mathrm{~h}(132 \mathrm{~d})$ for a fully charged tank to melt. The ambient temperature throughout this test remained between 65 and $85^{\circ} \mathrm{F}$, and there was no direct sunlight upon the tank.

Using Calmac's reported insulation thickness for the sides, an estimated average thickness of $4 \mathrm{in}$. for the top and $3 \mathrm{in}$. for the bottom, material conductivities from the ASHRAE manual, ${ }^{11}$ and an assumed temperature difference of $40^{\circ} \mathrm{F}$, the heat gain rate would be 0.07 ton, very close to the measured value.

\subsection{EUTECTIC PERFORMANCE}

A series of tests were made with a eutectic mixture of salts in the ice tank. Most of these tests were made under conditions chosen to duplicate tests made previously with water in the tank, as is shown in Tables 8 and 9 . Table 8 shows that when charge test conditions of compressor loading, condensing temperature, and brine flow rate were controlled to match the previous tests, the resulting capacity (as measured by the brine flow and temperature change across the storage tank coils) was $\sim 15 \%$ less with the eutectic than it had been with water in the tank. Figure 26 shows the capacity vs the cumulative stored energy for both the eutectic tests and the comparison tests. This shows that the decrease in capacity is relatively uniform throughout the charge test; that is, there is no major change in the shape of the capacity curve as the ice builds within the tank. Figure 27 shows the brine inlet temperature for these charge tests. Those tests made with the eutectic show lower brine temperatures,

Table 8. Eutectic charge test comparisons

\begin{tabular}{clccccc}
\hline $\begin{array}{c}\text { Test } \\
\text { ID }\end{array}$ & $\begin{array}{c}\text { Tank } \\
\text { contents }\end{array}$ & $\begin{array}{c}\text { Compressor } \\
\text { (hp) }\end{array}$ & $\begin{array}{c}\text { Compressor } \\
\text { loading } \\
(\%)\end{array}$ & $\begin{array}{c}\text { Condensing } \\
\text { temperature } \\
\left({ }^{\circ} \mathrm{F}\right)\end{array}$ & $\begin{array}{c}\text { Average } \\
\text { capacity } \\
\text { (ton) }\end{array}$ & $\begin{array}{c}\text { Brine } \\
\text { flow } \\
\text { rate } \\
\text { (gal/min) }\end{array}$ \\
\hline 0116 & Eutectic & 75 & 50 & 100 & 13 & 40 \\
1003 & Water & 75 & 50 & 100 & 15 & 40 \\
0119 & Eutectic & 40 & 75 & 80 & 17 & 60 \\
0929 & Water & 40 & 75 & 80 & 20 & 60 \\
0123 & Eutectic & 40 & 50 & 90 & 8 & 60 \\
1030 & Water & 40 & 50 & 90 & 9 & 60 \\
0126 & Eutectic & 40 & 100 & 90 & 15 & 80 \\
0928 & Water & 40 & 100 & 100 & 18 & 80 \\
\hline
\end{tabular}


Table 9. Eutectic discharge test comparisons

\begin{tabular}{clcccc}
\hline Test ID & $\begin{array}{c}\text { Tank } \\
\text { contents }\end{array}$ & $\begin{array}{c}\text { Brine } \\
\text { concentration } \\
(\mathbf{w t} \%)\end{array}$ & $\begin{array}{c}\text { Heater } \\
\text { power } \\
(\mathbf{k W})\end{array}$ & $\begin{array}{c}\text { Temperature } \\
\text { to load } \\
\left({ }^{\circ} \mathbf{F}\right)\end{array}$ & $\begin{array}{c}\text { Temperature } \\
\text { out load } \\
\left({ }^{\circ} \mathbf{F}\right)\end{array}$ \\
\hline 0111 & Eutectic & 25 & 39 & 42 & 60 \\
1101 & Water & 25 & 39 & 42 & 60 \\
0118 & Eutectic & 33 & 65 & 36 & 60 \\
1011 & Water & 33 & 65 & 36 & 60 \\
0122 & Eutectic & 33 & 39 & 38 & 50 \\
0125 & Eutectic & 33 & 65 & 45 & 50 \\
0129 & Eutectic & 33 & 78 & 45 & 50 \\
0927 & Water & 33 & 78 & 45 & 50 \\
\hline
\end{tabular}

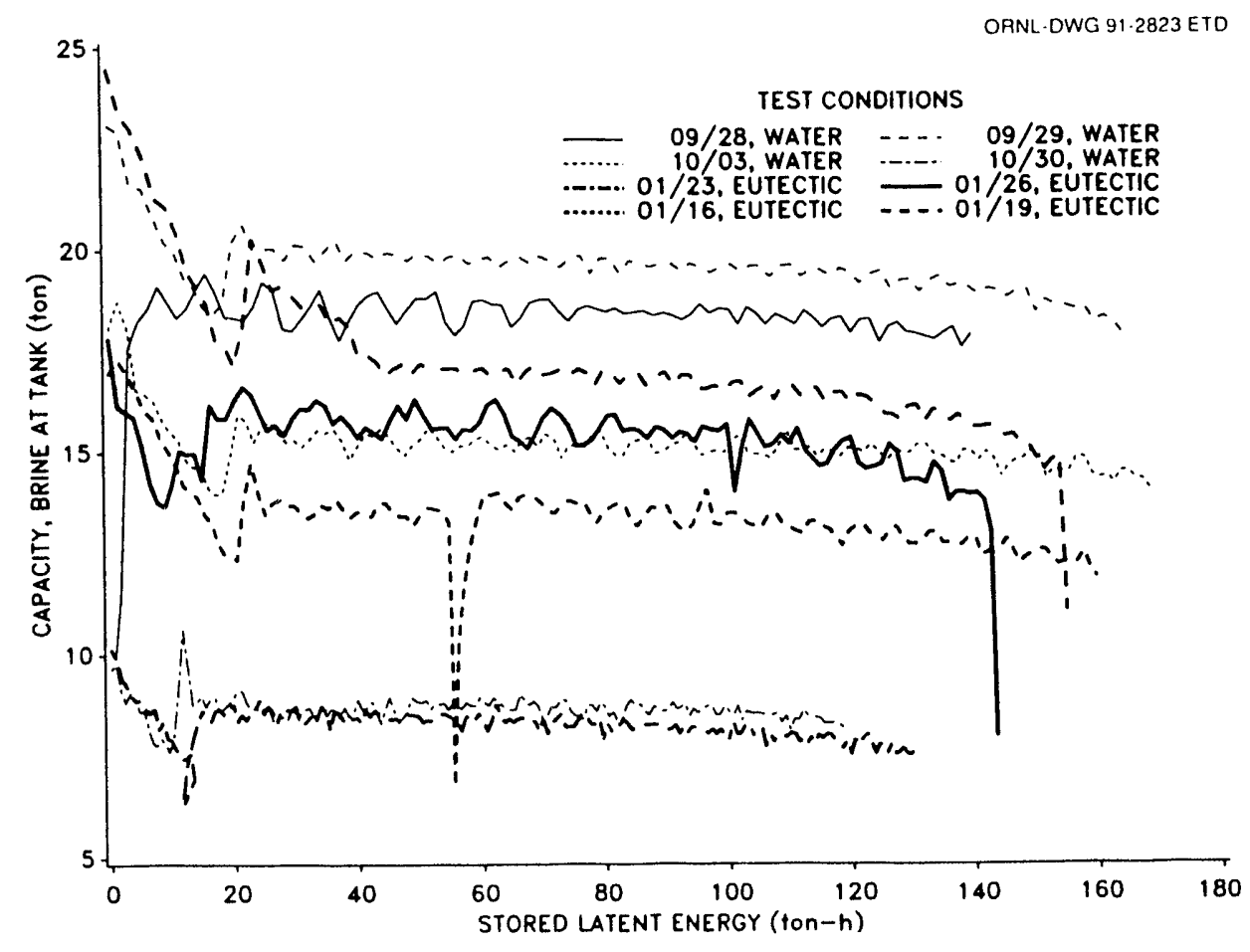

Fig. 26. Summary of Calmac charge tests with eutectic material in tank and brine concentration of $33 \%$, both capacity and stored latent energy based on brine temperature and flow measurements. All temperature measurements are $\pm 0.5^{\circ} \mathrm{F}$. 


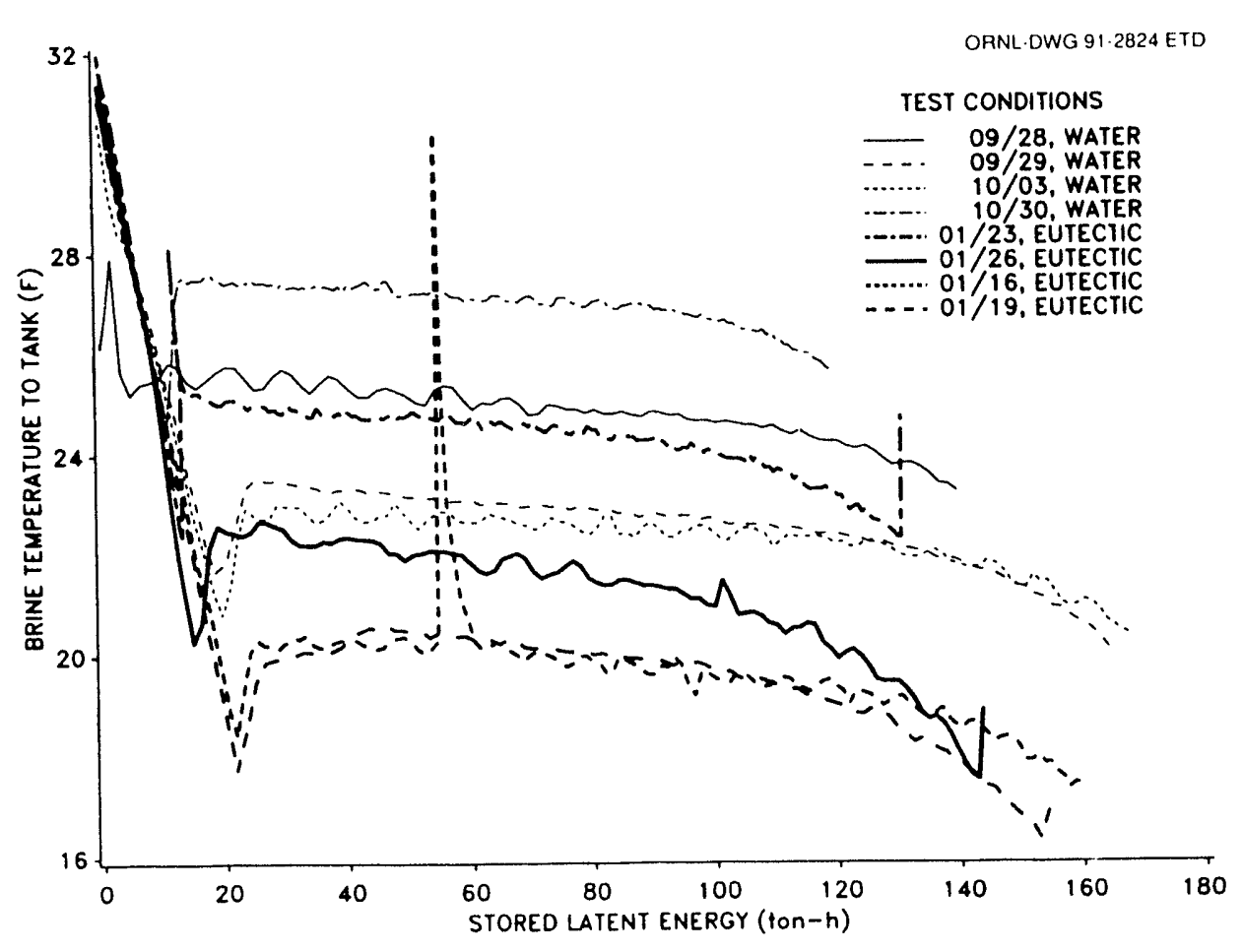

Fig. 27. Summary of tank brine inlet temperature profiles for Calmac charge tests with eutectic material and brine concentration of $33 \%$. All temperature measurements are $\pm 0.5^{\circ} \mathrm{F}$.

as expected. They also tend to show a gradual temperature drop throughout the charge, as compared to the more constant temperature exhibited by those tests made with water in the tank.

During normal operations, the tank would be frozen to a height of 6 in. above the fully melted height at the start of a discharge. At 19.7 ton-h/in., this represents $\sim 118$ ton-h of latent storage (both factors based on Calmac's $85 \%$ correction factor). The measured height at the start of the tests reported here ranged from 5.9 to 6.5 in. If the brine held in piping outside the tank reached room temperature before the beginning of the melt test, it would require $\sim 3$ ton-h to cool the brine down to $32^{\circ} \mathrm{F}$. Some of the slower melt tests took place over a 2 -d period, during which this brine inventory would need to be cooled down twice. These two effects, variation in initial ice inventory (from 116 to 128 ton-h) and brine heat gains (from 0 to 6 ton-h) during shutdown periods, cause the different starting points shown in Figs. 28 and 29.

Figure 28 shows the tank outlet temperature profile for three eutectic discharge tests ranging from 13 to 27 tons with a tank inlet temperature of $50^{\circ} \mathrm{F}$. Figure 29 compares the 


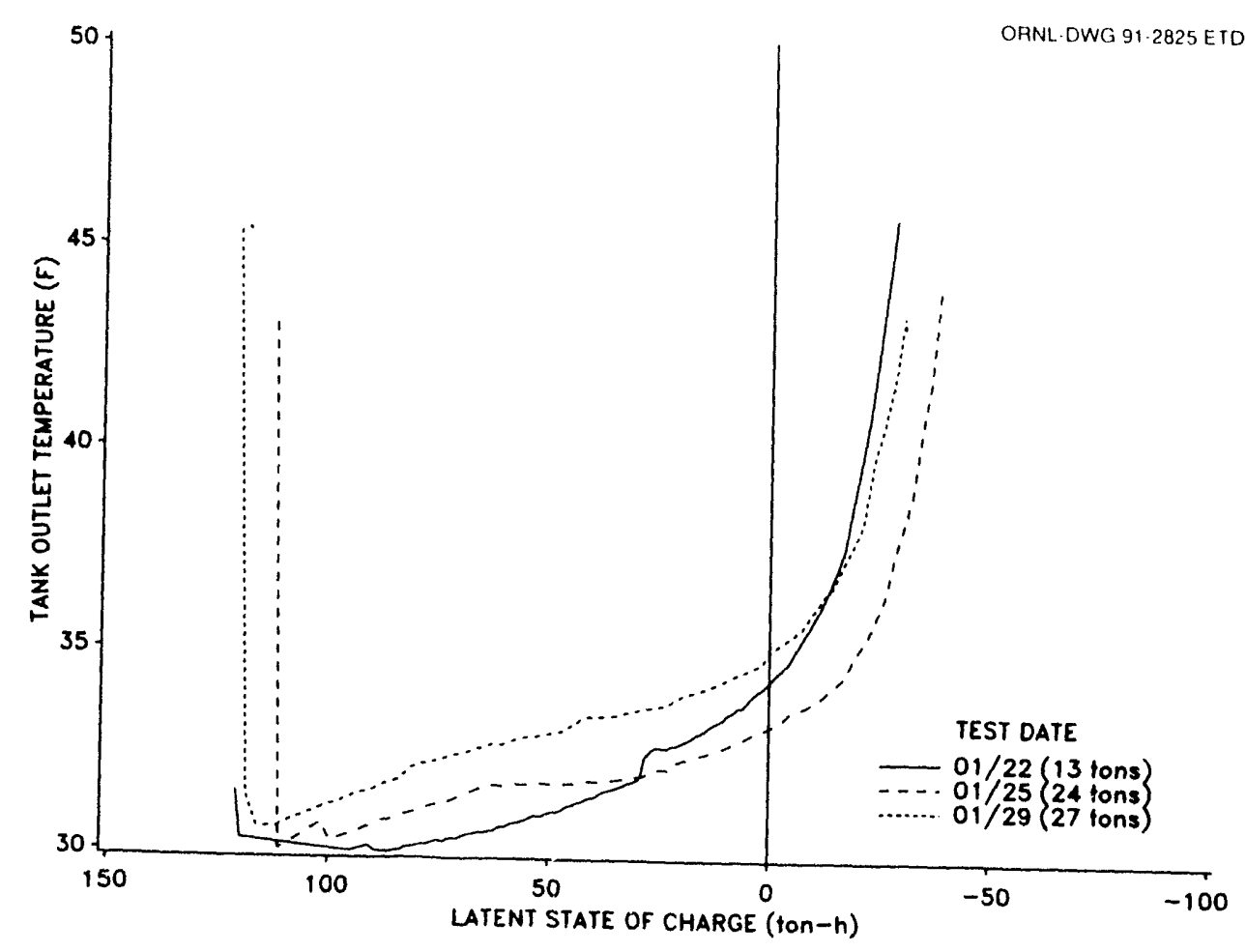

Fig. 28. Summary of Calmac discharge test tank outlet temperatures with tank inlet of $50^{\circ} \mathrm{F}$ and eutectic storage medium.

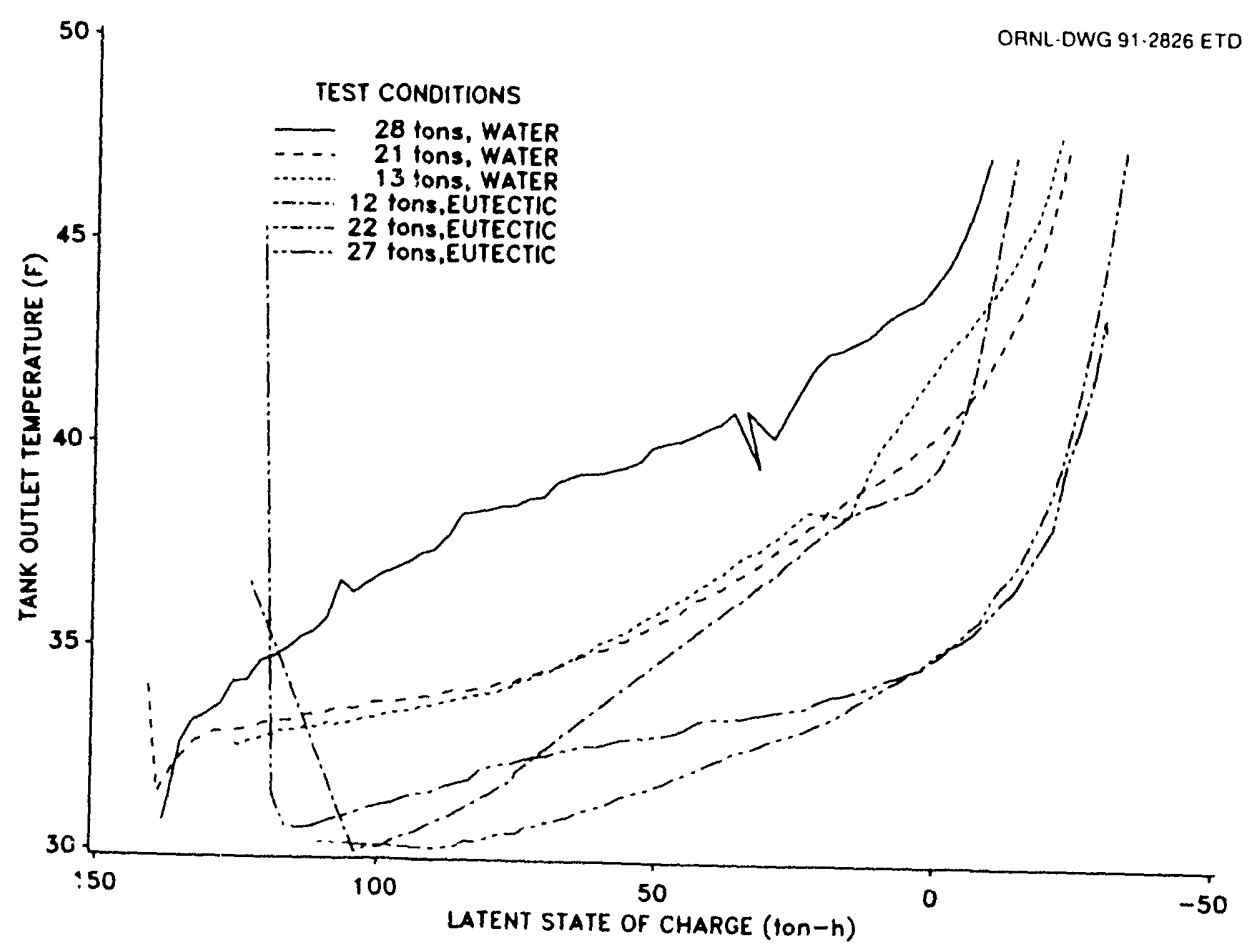
Fig. 29. Comparison of tank outlet temperature during discharge tests with eutectic
vs water as storage medium. 
tank outlet temperature profile for three eutectic tests with three similar tests made with water in the tank. At discharge :ates of $\sim 22$ to 27 tons, the eutectic shows a much colder tank outlet temperature over the entire discharge period compared to the similar tests made with water in the tank. However, at a discharge rate of $\sim 12$ tons, the eutectic tank outlet temperature is lower in the beginning, but rises to a temperature almost equal to that of the test with water during the latter half of the test. Nothing in the test log notes explains this behavior, a hough one of the two brine flowmeter data channels was found to contain bad data for this test. Also note that test 0122 , at a rate of 13 tons, is shown on Fig. 28 to provide tank outlet temperatures below $35^{\circ} \mathrm{F}$ until the latent energy is fully discharged.

As $u$ ith the tests made on a tank full on water, the discharge energy availability was examined as a function of the tank outlet temperature and compared to the manufacturer's literature. The results are shown in Figs. 30 and 31, for tank inlet temperatures of 50 and $60^{\circ} \mathrm{F}$, respectively. The Calm: $\mathrm{c}$ literature values shown on these plots represent the Calmac values for a tank filled with water multiplied by their suggested $85 \%$ correction factor. Calmac's values are conservative when compared to the ISTF data, with the exception of the data points (on Fig. 31) associated with the 12-ton discharge test discussed previously. Even for this test, the ISTF data values are very close to the Calmac predictions. Because fewer tests were made with the eutectic, regression analys could not meaningfully be used to represent ıne discharge energy availability as a function of time and tank outlet temperature. 


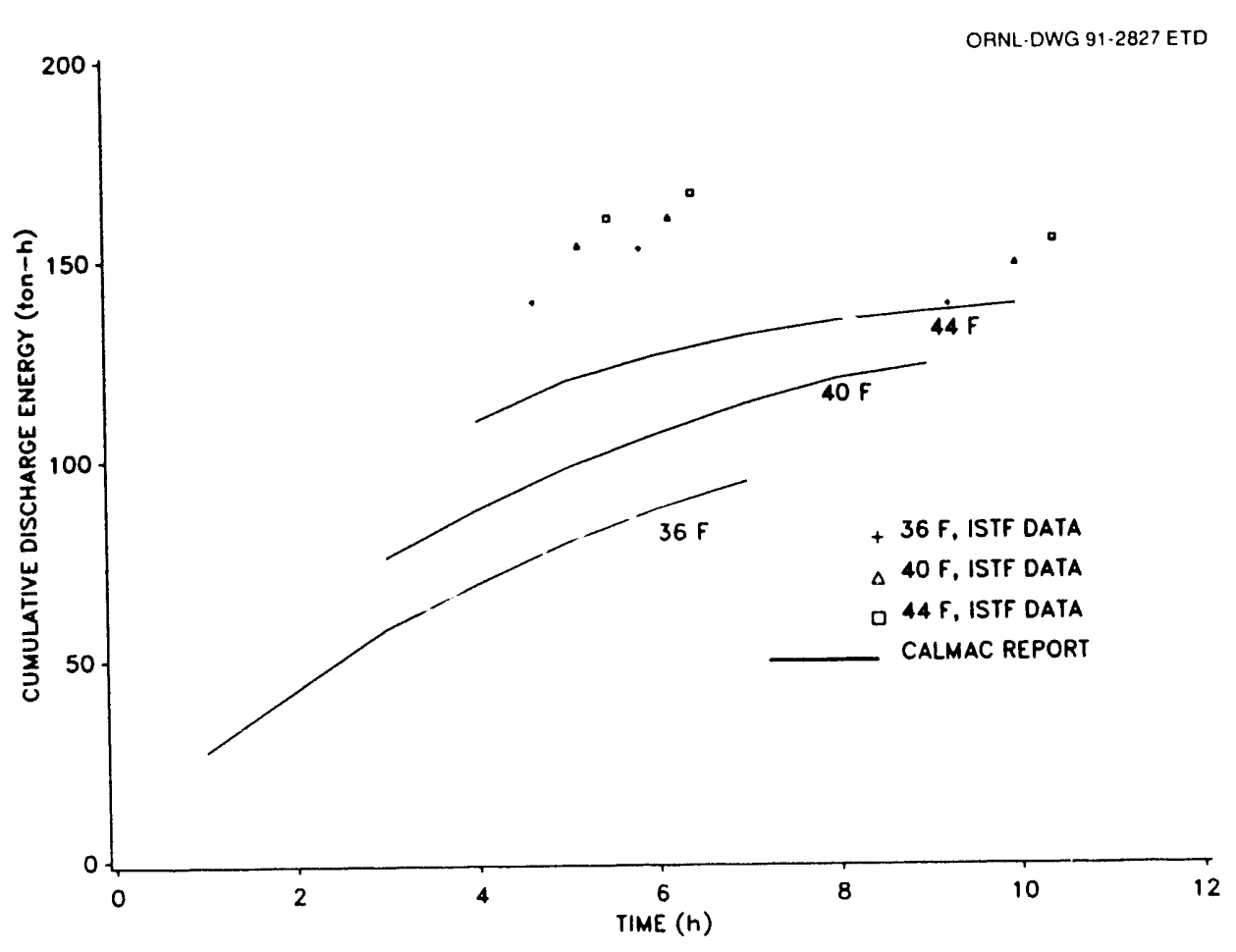

Fig. 30. Calmac discharge test summary for eutectic material with tank inlet temperature of $50^{\circ} \mathrm{F}$ : tank water outlet temperature vs tank latent state of charge. All temperature measurements are $\pm 0.5^{\circ} \mathrm{F}$.

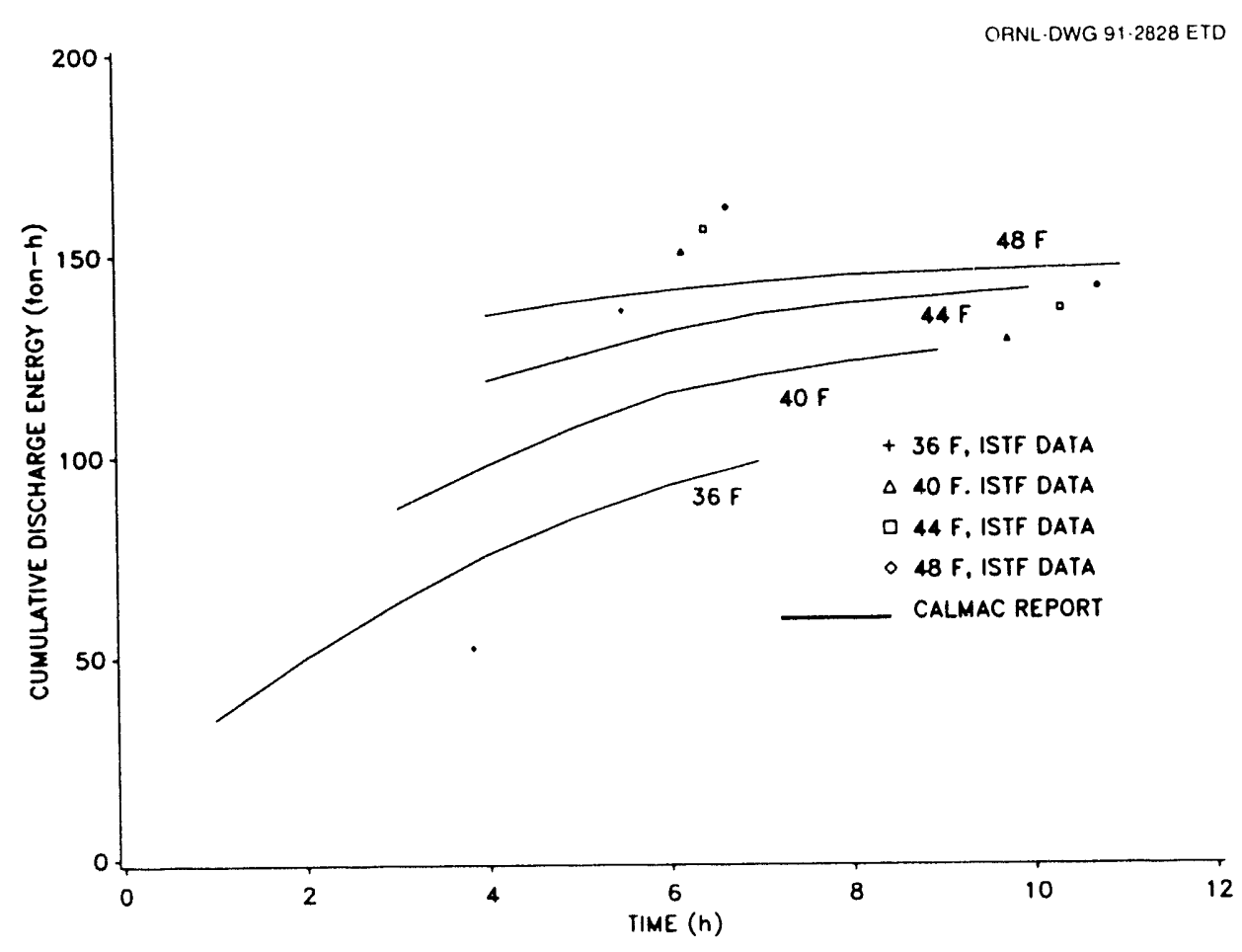

Fig. 31. Calmac discharge test summary for eutectic material with tank inlet temperature of $60^{\circ} \mathrm{F}$ : tank water outiet temperature vs tank latent state of charge. All temperature measurements are $\pm 0.5^{\circ} \mathrm{F}$. 


\section{CONCLUSIONS AND RECOMMENDATIONS}

The Calmac ice storage system tested was conisistently able to manufacture and store a full charge of ice. This was true for a wide range of charging rates, brine flow rates, and for two differe.tt brine concentrations. The discharge capacity is heavily dependent upon the discharge conditions, including discharge rate and brine temperature requirements.

The amount of capacity variation during a charge cycle, best shown by the normalized capacity plots, can have significant effects on the equipment performance and should be a primary factor in equipment selection. For this system, the amount of capacity variation was relatively insensitive to charging rate. Therefore, variations in operating schedules should not affect the charging performance for a given chiller system.

The discharge performance, however, was strongly dependent upon the tank discharge rate and tank outlet temperature. These parameters must therefore be clearly specified before the storage tank selection is made. Changes in the discharge schedule or required temperature after installation can alter the available discharge energy. 


\section{REFERENCES}

1. Calmac Manufacturing Corporation, LEVLOAD Ice Bank Performance Manual, Form IB-102 (3-89), Calmac Manufacturing Corporation, Englewood, N.J., 1989.

2. T. K. Stovall and J. J. Tomlinson, Commercial Cool Storage Laboratory Test Procedure, ORNL/TM-11511, Martin Marietta Energy Systems, Inc., Oak Ridge Natl. Lab., May 1990.

3. T. K. Stovall, Ice-Storage Efficiency Considerations, ORNL/TM-11678, Martin Marietta Energy Systems, Inc., Oak Ridge Natl. Lab., to be published.

4. G. T. Kartsounes and R. A. Erth, "Computer Calculaton of the Thermodynamic Properties of Refrigerants 12, 22, and 502," ASHRAE paper No. 2200, presented at ASHRAE Annual Meeting, Washington D.C., August 22-25, 1971.

5. UCARTHERM Heat Transfer Fluid, Union Carbide Corporation, Industrial Chemicals Division, Danbury, Conn., 1986.

6. P. V. Hobbs, Ice Physics, Clarendon Press, Oxford, 1974.

7. Calmac Manufacturing Corporation, Levload Ice Bank Technical Bulletin, "List Price Schedule Accessories for Levload Ice Banks," Calmac Manufacturing Corporation, Englewood, N.J., June 1989.

8. SAS User's Guide: Statistics, Version 5 Edition, SAS Institute Inc., Cary, N.C., 1985.

9. F. M. White, Viscous Fluid Flow, McGraw-Hill Book Co., New York, 1974, pp. 484-485.

10. Electric Power Research Institute, Commercial Cool Storage Design Guide, EM-3981, Palo Alto, Calif., May 1985.

11. 1985 ASHRAE Handbook, Fundamentals, American Society of Heating, Refrigerating and Air Conditioning Engineers, Inc., Atlanta, Ga., 1985, Sect. 6. 


\section{Appendix A}

\section{ISTF INSTRUMENTATION}

\section{A.1 DATA ACQUISITION AND CONTROL}

A data acquisition system and computer are used to control the thermal loading rate, the brine and refrigerant circulation pump speeds, recirculation valve positions, and the condensation temperature and to collect the data from system instrumentation. The computer allows short sampling times of the instrumentation to provide data for detailed analysis and feedback during transient system operation. Direct controls, outside of the data acquisition/computer system, are available for compressor loading, booster pump operation, and auxiliary portions of the test facility.

\section{A.2 TEMPERATURE MEASUREMENTS}

Refrigerant temperature measurements are made by RTDs bonded to the outside of the copper pipes. These RTDs were calibrated by the manufacturs: $r$ to $0.3^{\circ} \mathrm{F}$. After installation, the recorded refrigerant temperatures were compared to the expected thermodynamic states for the corresponding pressure measurements. Water and brine temperature measurements are made by RTDs inserted into the PVC pipes. These RTDs are calibrated by the manufacturer to $\pm 0.5^{\circ} \mathrm{F}$ and are checked against an ice bath after installation. The RTDs were also checked against each other under conditions where an unloaded heat exchanger, for example, would be expected to show the same inlet and outlet temperature. The RTD calibrations are periodically rechecked, and instruments that have drifted beyond $0.5^{\circ} \mathrm{F}$ are replaced.

\section{A.3 FLOW MEASUREMENTS}

Vortex-shedding flowmeters are used to measure the condenser cooling water flow, the water/brine flow to the heater, the water/brine flow to the ice tank, and the gaseous refrigerant flow to the condenser. The vortex-shedding refrigerant flowmeter imposes a pressure drop of $\sim 0.5 \mathrm{psia}$. These flowmeters are accurate to $\pm 0.8 \%$ of the reading for liquid flows and $\pm 1.5 \%$ of the reading for gaseous flows. The flowmeters used to measure 
water and brine volumetric flow were checked after installation by running water through the lines into a 55-gal drum placed on a scale.

The Coriolis mass flowmeters used to measure liquid refrigerant mass flows to the low-pressure receiver, the ice tank, and the thermal expansion valves were calibrated by the manufacturer to $\pm 0.4 \%$ of full scale, which is $1000 \mathrm{lb} / \mathrm{min}$. A sight glass is positioned to provide a visual confirmation of single-phase flow downstream of the meter. These Coriolis flowmeters are very difficult to calibrate after installation because of the closed nature of the refrigerant system. However, the volumetric flow through one of the vortex-shedding flowmeters can be compared to the mass flow through one of these Coriolis meters. Also, energy balances on the condenser, low-pressure receiver, chiller/evaporator, and ice tank can be used to assess the continued accuracy of these devices.

\section{A.4 PRESSURE MEASUREMENTS}

Refrigerant pressure measurements are made with pressure transducers to allow the electronic recording of the values. The accuracy of these absolute pressure readings is rated at $+0.11 \%$ of full scale. However, the calibration certificates supplied with each transducer show accuracies of $\pm 0.004 \%$ or better. Also, the transducer calibration was rechecked after installation and periodically thereafter using laboratory calibration equipment. The pressure transducers located in the high-pressure portion of the loop, that is, between the compressor discharge and the expansion valve, are rated for 0 to 500 psia. All others are rated for 0 to 250 psia. During testing, the pressure measurements are periodically compared to other measurements within the loop and to the expected refrigerant properties.

A differential pressure meter can be used to measure the change in tank water depth during charging. The meter measures from 0 to $10 \mathrm{in}$. of water with an accuracy of $\pm 0.5 \%$ of full range output (i.e., \pm 0.05 in. of water).

\section{A.5 ELECTRICAL MEASUREMENTS}

Electrical measurements for the compressor power (rated at 40 and $75 \mathrm{hp}$ ), circulating pump(s) power (from 2 to $5 \mathrm{hp}$ ), agitation air compressor power $(1 / 2 \mathrm{hp}$ ), and heater power ( 0 to $135 \mathrm{~kW}$ ) are measured by watt/watt-hour transducers. The watt-hour measurements are accurate to $\pm[0.2 \%$ of the reading $+0.01 \%$ of the rated output $) /($ power factor $)]$. The 
watt-hour meters for the compressors were checked by measuring the voltage and current on each of three phases. The watt-hour meter for the heater was checked by comparison to the heat absorbed by the water as measured by the flow and temperature change. The accuracy of this heater's watt-hour meter is poor because of the semiconductor-controlled rectifier (SCR), or phase-angle power controller, used to vary the heater power. Heater energy use measurements are therefore based on the fluid flow rate and temperature change, although the power consumption is recorded as an additional check.

\section{A.6 COOL STORED MEASUREMENT}

The change in storage medium volume is used to measure the amount of expansion due to ice formation for ice on coil systems. The amount of ice formation, along with the sensible heat removed from the storage medium indicates the quantity of cool stored in the tank. The differential pressure transducer described in a previous section was mounted at the initial water level in a section of tubing that was immersed in the tank at one end and fixed to a vertical support at the other. 
ORNL/TM-11582

Dist. Category UC-202

\section{Internal Distribution}

1. T. D. Anderson

2. V. D. Baxter

3. S. H. Buechler

4. R. S. Carlsmith

5. W. G. Craddick

6. P. D. Fairchild

7. D. J. Fraysier

8. W. Fulkerson

9. R. B. Honea

10. J. E. Jones Jr.

11. L. Jung

12. R. J. Kedl

13. M. A. Kuliasha

14. W. A. Miller
15. W. R. Mixon

16. M. Olszewski

17. A. E. Ruggles

18. A. C. Schaffhauser

19. M. Siman-Tov

20-29. T. K. Stovall

30. J. J. Tomlinson

31. C. D. West

32. G. L. Yoder

33. ORNL Patent Section

34. Central Research Library

35. Document Reference Section

36-37. Laboratory Records Department

38. Laboratory Records (RC)

\section{External Distribution}

39. John Stephen Anderpont, Chicago Bridge \& Iron Company, 800 Jorie Boulevard, Oak Brook, IL 60522-7001

40. Debra L. Catanese, P.E., Pennsylvania Electric Company, 311 Industrial Park Rd., Johnstown, PA 15904

41. Tom Carter, Baltimore Aircoil Company, P.O. Box 7322, Baltimore, MD 21227

42. Russ Eaton, Director, Advanced Utility Concepts Division, U.S. Department of Energy, Forrestal Building, CE-142, 1000 Independence Avenue, Washington, DC 20585

43. Imre Gyuk, Office of Energy Storage and Distribution, U.S. Department of Energy, Forrestal Building, CE-32, 1000 Independence Avenue, Washington, DC 20585

44. Landis Kannberg, Battelle Pacific Northwest Laboratories, P.O. Box 999, Battelle Boulevard, Richland, WA 99352

45. Don Kemp, Turbo Refrigerating Company, 1815 Shady Oaks Drive, P.O. Box 396, Denton, TX 76202

46. K. W. Klunder, Director, Office of Energy Management, Department of Energy, CE-14, Forrestal Building, 1000 Independence Avenue, Washington, DC 20585

47. Dave Knebel, Paul Mueller Company, P.O. Box 828, Springfield, MO 65801-0828

48. David Laybourn, P.E., Director of Marketing, Reaction Thermal Systems, Inc., 840 Latour Court, Suite A, Napa, CA 94558

49. George Manthey, DOE, Oak Ridge Operations, Oak Ridge, TN 37831

50. Robert P. Miller, Baltimore Aircoil Company, P.O. Box 7322, Baltimore, MD 21227

51. Tony Min, Mechanical Engineering Department, North Carolina Agricultural and Technical State University, Greensboro, NC 27411 
52. Dave Pellish, U.S. Department of Energy, Forrestal Building, MS CE-332, Room 5H-79, 100 Independence Avenue, Washington, DC 20585

53. Veronika A. Rabl, Electric Power Re search Institute, 3412 Hillview Avenue, P.O. Box 10412, Palo Alto, CA 94303

54. Eberhart Reimers, Advanced Utility Concepts Division, U.S. Department of Energy, Forrestal Building, CE-142, 1000 Independence Avenue, Washington, DC 20585

55. Richard Rhodes, FAFCO, Inc., 235 Constitution Drive, Menlo Park, CA 94025

56. Marwan Saliba, Energy Engineering Institute, Dept. of Mechanical Engineering, San Diego State University, San Diego, CA 92182-0191

57. Brian Silvetti, Calamac Manufacturing Corporation, Box 710, 150 South Van Brunt Street, Englewood, NJ 07631

58. Robert L. San Martin, Deputy Assistant Secretary, Office of Utility Technology, Department of Energy, CE-10, 6C-026/Forrestal Bldg., 1000 Independence Avenue, Washington, DC 20585

59. Chang W. Sohn, U.S. Army Corps of Engineers, P.O. Box 4005, Champaign, IL 61824-4005

60. Laura Thomas, Marketing Manager, York International Corporation, P.O. Box 1592, York, PA 17405-1592

61. Samuel G. Tornabene, Edison Electric Institute, 1111 19th Street, N.W., Washington, DC 20036-3691

62-71. R. D. Wendland, Electric Power Research Institute, 3412 Hillview Avenue, Box 10412, Palo Alto, CA 94303

72. Maurice W. Wildin, Professor, The University of New Mexico, Department of Mechanical Engineering, Albuquerque, NM 87131

73. Office of Assistant Manager for Energy Research and Development, Department of Energy, ORO, Oak Ridge, TN 37831

74-85. Given distribution as shown in DOE/OSTI-4500-R75 under Category UC-202 (Thermal Energy Storage) 

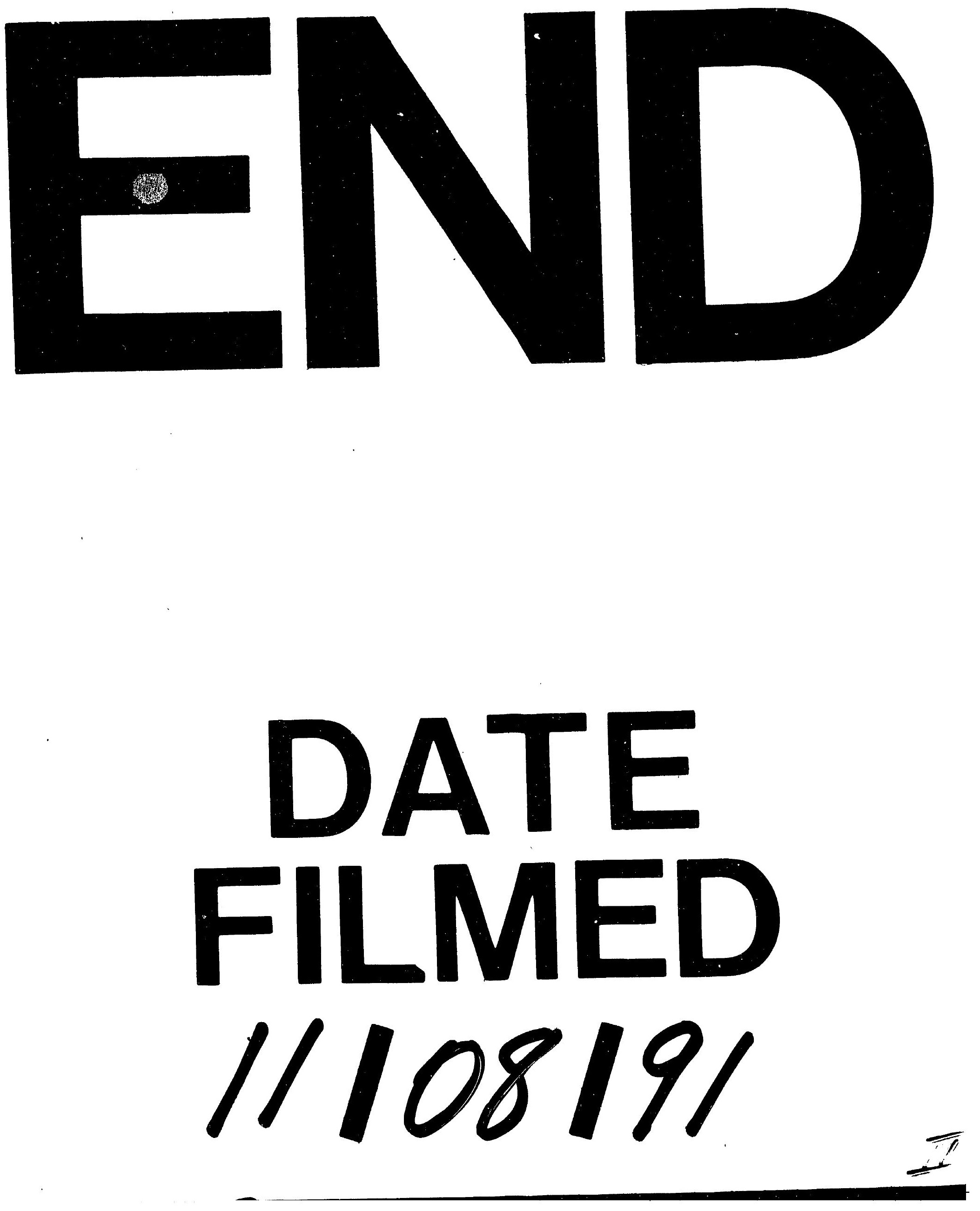
